\title{
The FIT 2.0 Model - Fuel- Cycle Integration and Tradeoffs
}

Steven J. Piet

Nick R. Soelberg

Layne F. Pincock

Eric L. Shaber

Gregory M. Teske

June 2011

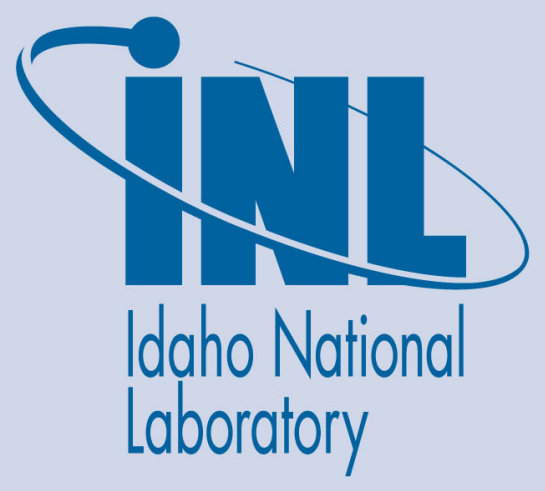

The INL is a U.S. Department of Energy National Laboratory operated by Battelle Energy Alliance 
INL/EXT-10-20190

FCR\&D-SYSA-2010-000192

Rev. 1

\title{
The FIT 2.0 Model - Fuel-Cycle Integration and Tradeoffs
}

\author{
Steven J. Piet \\ Nick R. Soelberg \\ Layne F. Pincock \\ Eric L. Shaber \\ Gregory M. Teske
}

June 2011

\author{
Idaho National Laboratory \\ Fuel Cycle Research \& Development \\ System Analysis Campaign \\ Separations Campaign \\ Fuels Campaign \\ Idaho Falls, Idaho 83415
}

Prepared for the

U.S. Department of Energy

Office of Nuclear Energy

Under DOE Idaho Operations Office

Contract DE-AC07-05ID14517 


\section{DISCLAIMER}

This information was prepared as an account of work sponsored by an agency of the U.S. Government. Neither the U.S. Government nor any agency thereof, nor any of their employees, makes any warranty, expressed or implied, or assumes any legal liability or responsibility for the accuracy, completeness, or usefulness, of any information, apparatus, product, or process disclosed, or represents that its use would not infringe privately owned rights. References herein to any specific commercial product, process, or service by trade name, trade mark, manufacturer, or otherwise, does not necessarily constitute or imply its endorsement, recommendation, or favoring by the U.S. Government or any agency thereof. The views and opinions of authors expressed herein do not necessarily state or reflect those of the U.S. Government or any agency thereof. 


\section{SUMMARY}

All mass streams from fuel separation and fabrication are products that must meet some set of product criteria - fuel feedstock impurity limits, waste acceptance criteria (WAC), material storage (if any), or recycle material purity requirements such as zirconium for cladding or lanthanides for industrial use. These must be considered in a systematic and comprehensive way. The FIT model and the "system losses study" team that developed it [Shropshire2009, Piet2010b] are steps by the Fuel Cycle Technology program toward an analysis that accounts for the requirements and capabilities of each fuel cycle component, as well as major material flows within an integrated fuel cycle. This will help the program identify near-term R\&D needs and set longer-term goals. This report describes FIT 2, an update of the original FIT model.[Piet2010c]

FIT is a method to analyze different fuel cycles; in particular, to determine how changes in one part of a fuel cycle (say, fuel burnup, cooling, or separation efficiencies) chemically affect other parts of the fuel cycle. FIT provides the following:

- Rough estimate of physics and mass balance feasibility of combinations of technologies. If feasibility is an issue, it provides an estimate of how performance would have to change to achieve feasibility.

- Estimate of impurities in fuel and impurities in waste as function of separation performance, fuel fabrication, reactor, uranium source, etc.

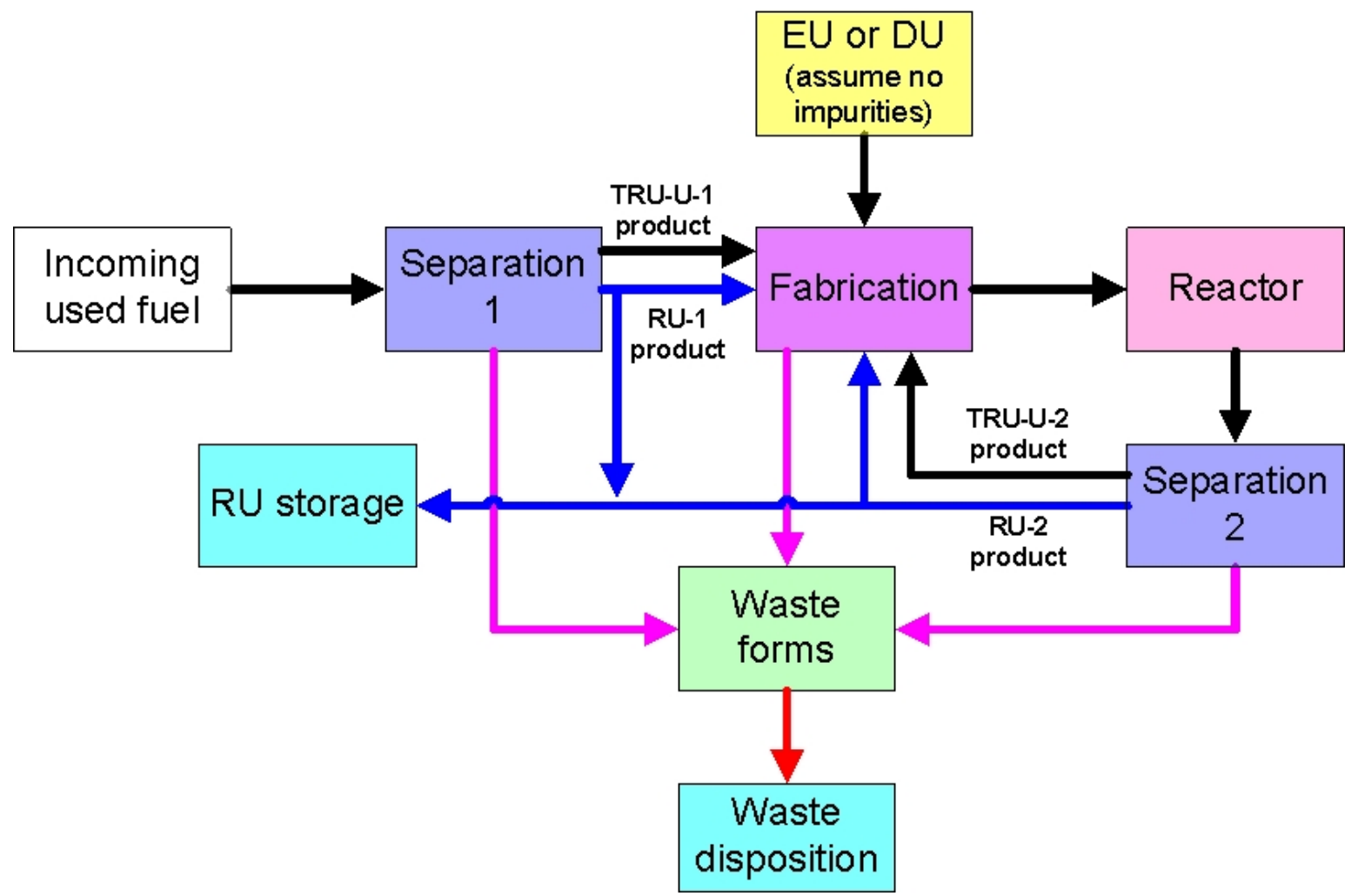

Figure S-1. Basic mass flows; the tool does not yet address EU feed.

FIT is a "mass flow engine" (Figure S-1) that posits an incoming flow of used fuel, an initial separation with mass flows to fabrication and waste forms. Recycling flows link a second separation of used fuel to a reactor and fabrication in a loop. The feed stream blending module associated with fuel fabrication can 
mix the TRU-rich (TRU-U-1) and recovered uranium (RU-1) products from separation-1, the TRU-U-2 and RU-2 products from separation-2, and depleted uranium (DU) to keep the mixture's k-infinity approximately equal to that for a user-selected impurity-free fuel recipe. The flow of TRU-U-1 is kept constant; the flow of TRU-U-2 is the residual mass from the preceding recycle. This defines the TRUrich TRU-U stream for blending. The selection among RU-1, RU-2, or DU as the source of uranium for blending with the TRU-U stream is user controlled. Users can add or change the user-defined separation matrices ( $\mathrm{x} \%$ of elements go into which product stream).

Neither the separation factors nor the working fuel impurity limits used here are in any sense formal or final. Both are subject to R\&D results and analysis. Indeed, one purpose of FIT is to assist in identifying where working values come into problems and some of the impacts from different values.

Table S-1 lists the types of cases that FIT can analyze.

Table S-1. Current and potential use cases

\begin{tabular}{|l|l|l|l|}
\hline Fuel cycle step & Cases in FIT 2.0 files & $\begin{array}{c}\text { Other cases that can be run } \\
\text { by FIT 2.0 }\end{array}$ & $\begin{array}{c}\text { Cases that cannot be } \\
\text { run by FIT 2.0 }\end{array}$ \\
\hline Incoming used fuel & LWR-UOX-51 & $\begin{array}{l}\text { Any U/Pu fuel cycle case } \\
\text { for which detailed isotope } \\
\text { data exist }\end{array}$ & Th/U233 fuel cycles \\
\hline $\begin{array}{l}\text { Separation 1 } \\
\text { (separation } \\
\text { technology used on } \\
\text { incoming used fuel) }\end{array}$ & $\begin{array}{l}\text { Electrochemical } \\
\text { AIROX } \\
\text { Melt refining } \\
\text { PUREX }\end{array}$ & $\begin{array}{l}\text { Any separation technology } \\
\text { for which separation matrix } \\
\text { can be provided or guessed. }\end{array}$ & \\
\hline $\begin{array}{l}\text { Sources of uranium } \\
\text { for blending to make } \\
\text { recycle fuel }\end{array}$ & $\begin{array}{l}\text { RU from separation 1 } \\
\text { RU from separation 2 } \\
\text { Depleted uranium }\end{array}$ & None & $\begin{array}{l}\text { Enriched uranium } \\
\text { Natural uranium }\end{array}$ \\
\hline $\begin{array}{l}\text { Original (impurity- } \\
\text { free) recycle fuel }\end{array}$ & $\begin{array}{l}\text { FR, metal, CR=0.50 } \\
\text { FR, oxide, CR=0.50 }\end{array}$ & $\begin{array}{l}\text { Fuel types other than metal } \\
\text { and oxide for which user } \\
\text { has appropriate loss and } \\
\text { fabrication information }\end{array}$ & $\begin{array}{l}\text { Breeder reactor } \\
\text { Th/U233 fuel cycles }\end{array}$ \\
$\begin{array}{l}\text { Separation 2 } \\
\text { (separation } \\
\text { technology used on } \\
\text { used recycle fuel) }\end{array}$ & $\begin{array}{l}\text { Eny separation technology } \\
\text { AIROX } \\
\text { Melt refining } \\
\text { PUREX }\end{array}$ & $\begin{array}{l}\text { for which separation matrix } \\
\text { can be provided or guessed. }\end{array}$ & \\
\hline $\begin{array}{l}\text { - Changing the model to allow natural uranium, enriched uranium, or breeder reactors should be } \\
\text { relatively straightforward. }\end{array}$ \\
$\begin{array}{l}\text { Changing the model to allow Th/U233 fuel cycles would also require new versions of MrTauWinery } \\
\text { (spreadsheet, makes the input fuel adjustment) and MrTau (Fortran executable, calculates fuel output) } \\
\text { that address Th and U233. }\end{array}$
\end{tabular}

The changes from FIT 1.0 are as follows:

- FIT 2.0 calculates each individual element, whereas FIT 1.0 grouped chemically similar elements, e.g., all the halogens together. The problem with the grouping approach is that the phrase "chemically similar" depends on what processes are involved in a given analysis. 
- Like FIT 1.0, FIT 2.0 adjusts the input fuel recipe (U versus TRU ratio) via 1-group cross sections to match the k-infinity of an original fuel recipe. FIT 2.0's adjustment uses cross sections for hundreds of fission product isotopes, providing a better approximation. FIT 1.0 used lumped cross sections for groups of elements.

- Like FIT 1.0, FIT 2.0 calculates the actinide portion of the output fuel composition via the MrTau depletion model.[Alfonsi2011] FIT 1.0 obtained fission product increments from the original unadjusted fuel recipe. FIT 2.0 obtains fission product output from an update of MrTau, except where MrTau's results are not yet trustworthy (determined by a built-in test in FIT). Outside of the FIT task, separate funding will provide an update of MrTau that is expected to better estimate more fission products. If so, it will simply replace the current MrTau, and FIT will automatically adjust fewer isotopes via the trustworthy test.

- Like FIT 1.0, FIT 2.0 does not provide for calculation of non-fission product activation products, e.g., Co60 from Co59. But, it does track the mass of each non-fission product element, whereas FIT 1.0 did not.

- More user-inputs have been moved to the "Control" worksheet. The user will typically only need go to other worksheets when inputting new separation matrices or input/output fuel recipes.

- The choice of separation matrices now include PUREX and a blank for users to modify without having to cannibalize the supplied UREX +1 , electrochemical, AIROX, and melt refining matrices. PUREX was added to address a quick-response question from DOE.

- The model outputs have been expanded to two tabs and provide more information than was provided in FIT 1.0. One output tab ("Output") shows key parameters (heat, gamma, neutron, radiotoxicity, mass, and volume) for each output waste stream, fuel blending fractions, reactor burnup, and reactor power, for each recycle iteration. The other output tab ("Output2") shows, for each iteration, elemental and isotopic mass flows through the model from separations-1 through fuel fabrication and reactor and separations-2 (or to waste streams).

- The working-value separation matrices have been updated. Grouped elements have been divided into individual elements, see Appendix A. As new information or estimates have been provided by Separations Campaign researchers or developed from reviews of prior literature, some separation factors have been updated.

- The FY10 calculations for the losses study [Piet2010b] have been updated, see Appendix B.

- Illustrative waste results are in Appendix C.

Additional capabilities, subject to program priorities, that could be added in the future include tracking of impurities other than fission products, options for input of enriched uranium (EU) and/or natural uranium (NU), breeder reactors, thorium fuels, economics, and an "optimizer" or "solver" that would automatically iterate the mass flow engine to balance criteria or to meet a particular criteria.

Appendix B updates the losses study calculations with FIT 2. In the original losses study and FIT 1 report, we indicated that the transition metals were significantly uncertain, which was a motivation for the element-by-element approach in FIT 2. Indeed, those elements treated as individual elements in FIT2 and FIT1 only changed significantly when the working-value separation factors changed. But, individual transition metals often moved up and down by factors of 2 to 10 . 
For oxide fuels, the broad results are similar to FIT 1. Most elements limited by the Fuels Campaign (2009 working limits) and were indicated as potential problems with FIT 1 are now even higher with FIT 2.

AIROX cannot be used to process LWR-UOX fuel to make fast reactor fuel. If UREX+1 is used to process LWR-UOX fuel, but AIROX used on used fast reactor fuel, 3 recycles are theoretically possible from the physics standpoint. (The first recycle is solely UREX +1 fed because there is no used FR fuel yet.) But, the second recycle in the AIROX case (the first in which AIROX is itself used), several impurity limits are exceeded, e.g., lanthanides. Thus, in short, AIROX does not work for this application of repeated recycling.

When UREX +1 is used to process both LWR-UOX and fast reactor fuel, we have the following results:

- 2009 working limits met - lanthanides, group 1 (alkali metals), group 2 (alkaline earths)

- 2009 working limits not met $-\mathrm{Mo}+\mathrm{Ag}, \mathrm{Ru}, \mathrm{Cd}+\mathrm{Sn}$ - these are 2-4x times higher with FIT 2 than FIT 1 because of element-specific treatment.

- Elements not covered by 2009 working limits but predicted to accumulate $>100 \mathrm{ppm}-\mathrm{Zr}$, Tc, $\mathrm{Pd}$, and Te. The Pd results are higher; the Te results are lower than FIT 1.

For metal fuels, the broad results are similar to FIT 1. There are smaller changes with FIT 2 from FIT 1 than for oxide fuels because we have fewer element-specific data for electrochemical. But, remember that the electrochemical cases still use UREX+1 on the used LWR-UOX fuel, so element-specific treatment can, and do, change results.

Melt refining cannot be used to process LWR-UOX fuel to make fast reactor fuel. If UREX+1 is used to process LWR-UOX fuel, but melt refining used on used fast reactor fuel, 3 recycles are theoretically possible from the physics standpoint (the first recycle is solely UREX +1 fed because there is no used FR fuel yet). But, the second recycle in the melt refining case (the first in which melt refining is used), several impurity limits are exceeded. Thus, in short, melt refining does not work for this application of repeated recycling.

When UREX+1 is used to process LWR-UOX and electrochemical is used on fast reactor fuel, we have the following results:

- 2009 working limits met - cadmium

- 2009 working limits not met - lanthanides and molybdenum.

- Elements not covered by 2009 working limits but predicted to accumulate $>100 \mathrm{ppm}$ - group2 (alkaline earths), Tc, Ru, Rh, Pd, and Sn. The Pd results are higher; the Te results are lower than FIT 1. 


\section{CONTENTS}

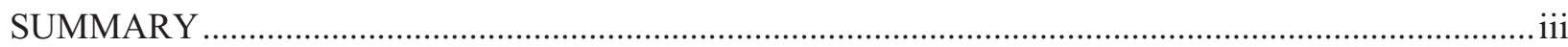

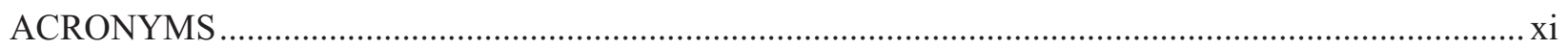

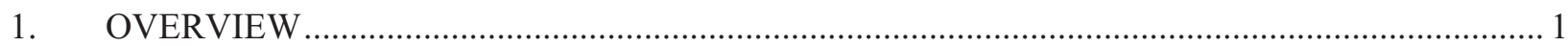

$1.1 \quad$ Purpose

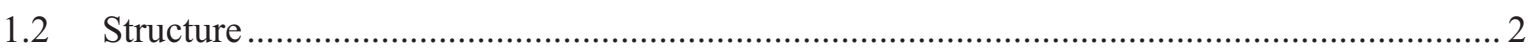

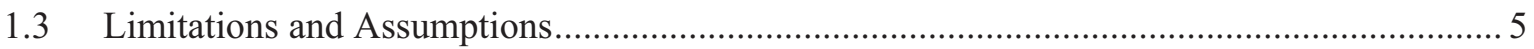

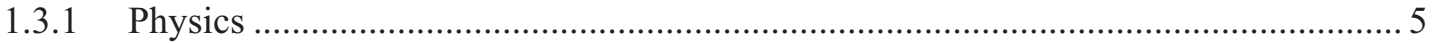

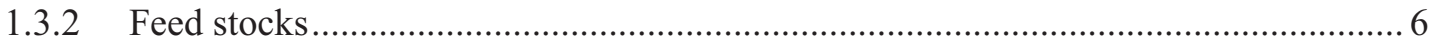

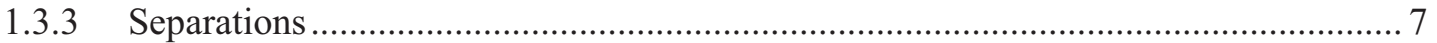

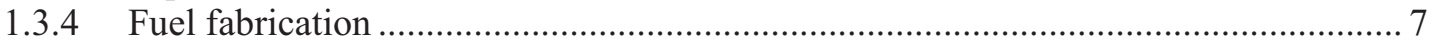

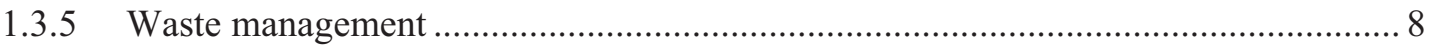

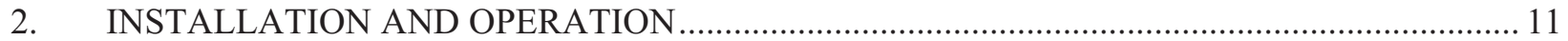

3. INPUTS AND DESCRIPTION OF EACH WORKSHEET ……............................................. 13

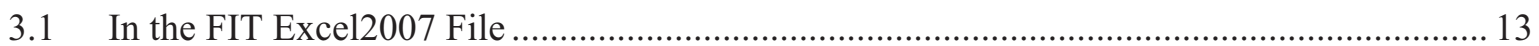

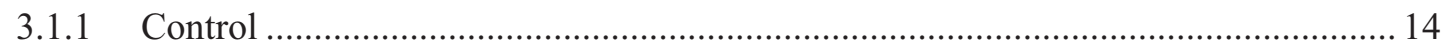

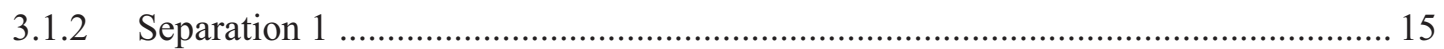

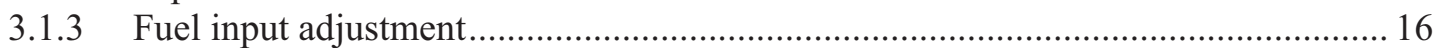

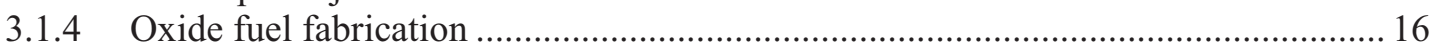

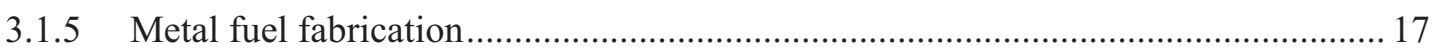

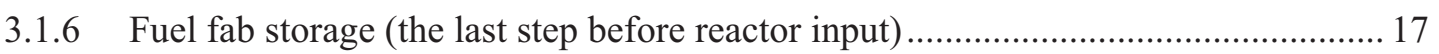

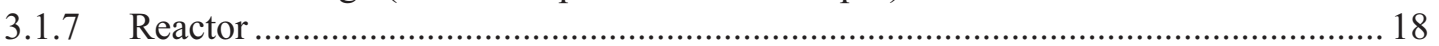

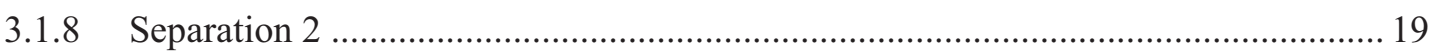

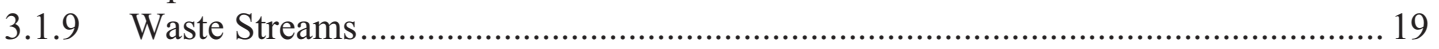

3.2 In MrTauWinery Excel2007 File

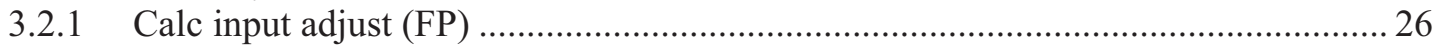

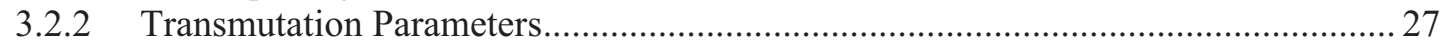

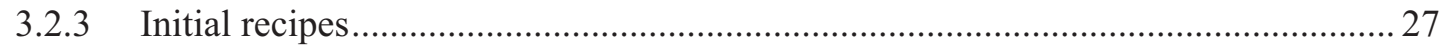

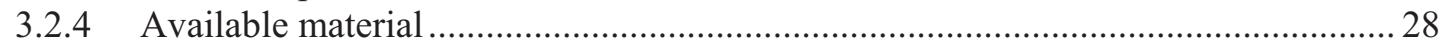

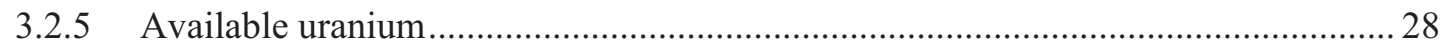

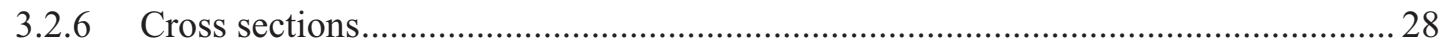

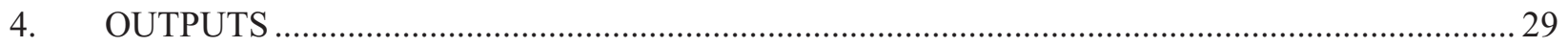

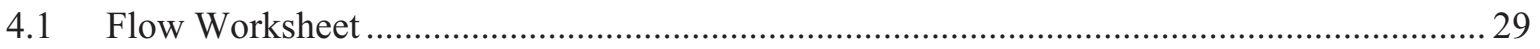

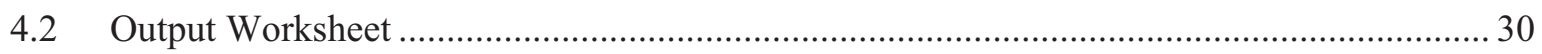

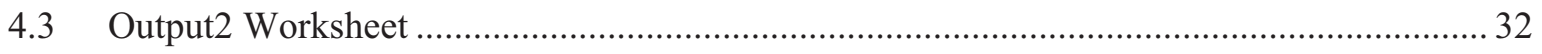

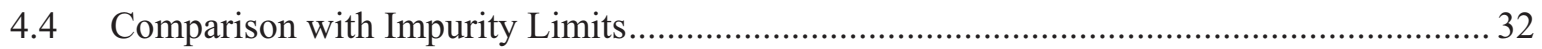

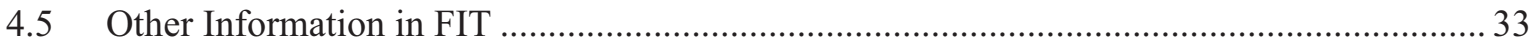

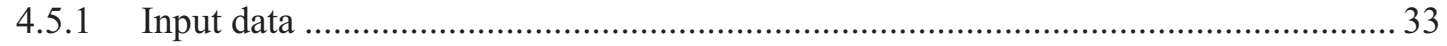

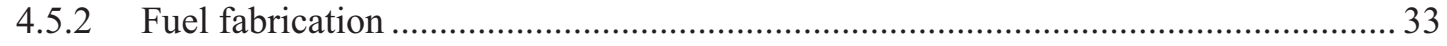

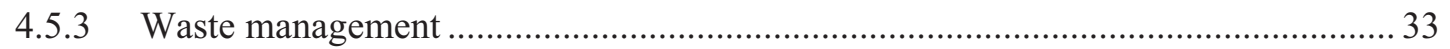

4.6 Other Information in MrTauWinery Excel2007 File ........................................................ 34 


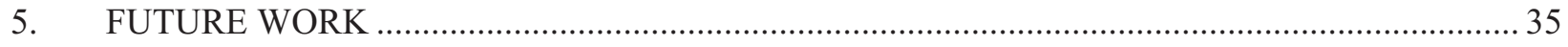

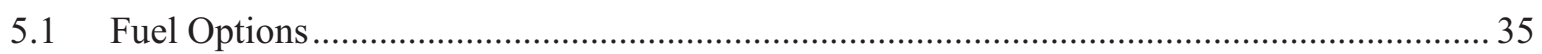

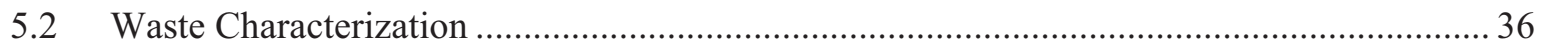

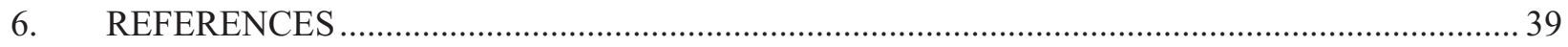

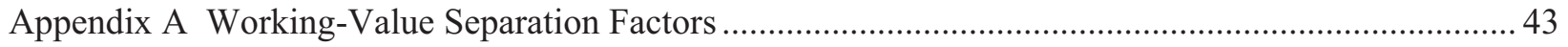

A.1 Current Status of Working-Value Separation Factors ............................................................ 45

A.2 UREX+1a Separation Factors - FIT 2.0 Updates from FIT 1.0 …....................................... 46

A.3 Echem Separation Factors - FIT 2.0 Updates from FIT 1.0 ................................................. 47

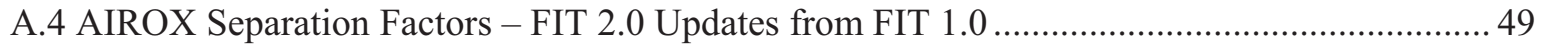

A.5 Melt Refining Separation Factors - FIT 2.0 Updates from FIT 1.0 …................................... 51

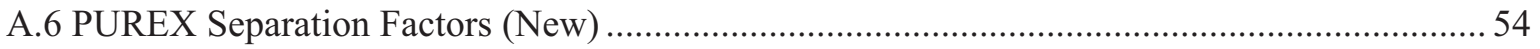

Appendix B Illustrative Impurity Accumulation Calculations using UREX +1 , Electrochemical,

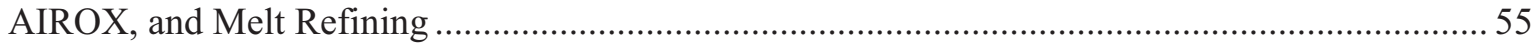

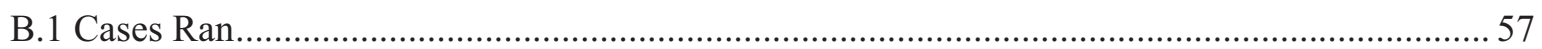

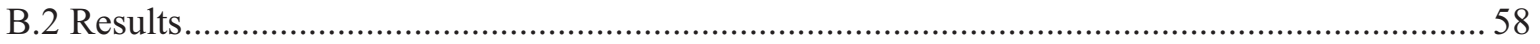

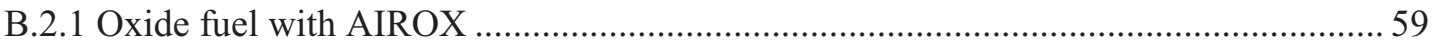

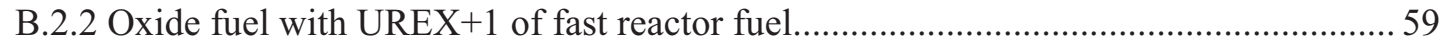

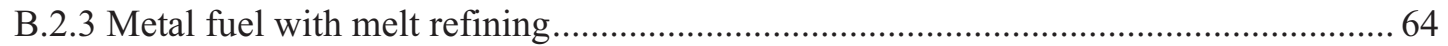

B.2.4 Metal fuel with electrochemical refining of fast reactor fuel ..................................... 65

Appendix C Illustrative Waste Results using a UREX+1 Example Case.............................................. 69

\section{FIGURES}

Figure S-1. Basic mass flows; the tool does not yet address EU feed. ...................................................iii

Figure 1-1. Basic mass flows; FIT 2.0 does not yet address EU feed as an option. ................................... 3

Figure 1-2. Technological choices (green) and information flows (red) overlaying mass flows

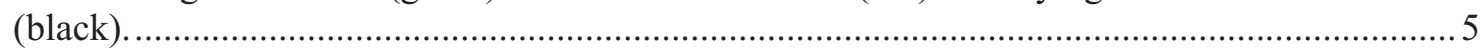

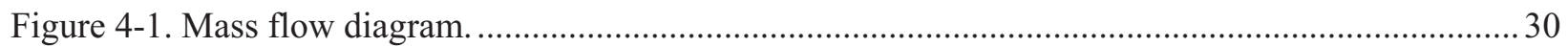

Figure 4-2. Illustration of the tritium and C-14 waste form output page on worksheet Grout in the

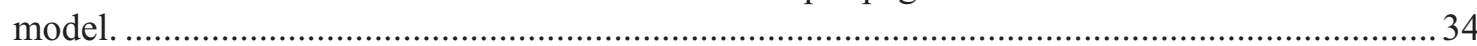

Figure 4-3. Glass waste form model execution calculation worksheet OUTPUT- \& Assumptions_WP

Figure B1. Composition for fast reactor oxide fuel: UREX+1 on LWR-UOX fuel and AIROX on FR fuel.

Figure B2. Composition for fast reactor oxide fuel: UREX+1 on LWR-UOX and FR fuel, RU feed.

Figure B3. Composition for fast reactor oxide fuel: UREX+1 on LWR-UOX and FR fuel, DU feed. 
Figure B4. Lanthanide content for fast reactor oxide fuel, UREX+1 is always used on used LWRUOX.

Figure B5. Group1 content for fast reactor oxide fuel, UREX+1 is always used on used LWR-

UOX.

Figure B6. Group2 content for fast reactor oxide fuel, UREX+1 is always used on used LWR-

UOX.

Figure B7. Mo+ $\mathrm{Ag}$ content for fast reactor oxide fuel, UREX+1 is always used on used LWRUOX.

Figure B8. Ru content for fast reactor oxide fuel, UREX +1 is always used on used LWR-UOX8 63

Figure B9. $\mathrm{Cd}+\mathrm{Sn}$ content for fast reactor oxide fuel, UREX+1 is always used on used LWRUOX

Figure B10. Composition for fast reactor metal fuel: UREX+1 on LWR-UOX fuel and melt refining on FR fuel.

Figure B11. Composition for fast reactor metal fuel: UREX+1 on LWR-UOX and FR fuel, RU feed.

Figure B12. Composition for fast reactor metal fuel: UREX+1 on LWR-UOX and FR fuel, DU feed.

Figure B13. Lanthanide content for fast reactor metal fuel, UREX+1 is always used on used LWR-UOX.

Figure B14. Molybdenum content for fast reactor metal fuel, UREX+1 is always used on used LWR-UOX.

Figure B15. Cadmium content for fast reactor metal fuel, UREX+1 is always used on used LWRUOX 68

Figure C1. Cells for documenting waste stream mass from separations, user-input values for waste loading and waste form density, and resultant final waste form mass and volume.

Figure C2. Waste stream output for the BSG waste form for Case 5. .71

Figure C3. Waste stream output information. .72 73

\section{TABLES}

Table S-1. Current and potential use cases ......................................................................................iv

Table 3-1. Navigation choices on Control Worksheet (color coded in the FIT Excel2007 file).............. 13

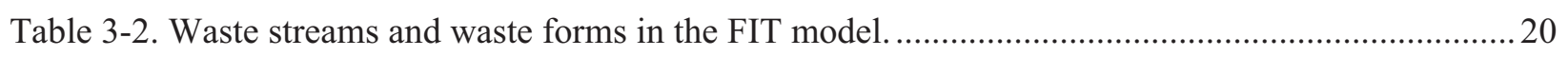

Table 4-1. Information available on the Output Worksheet. ..................................................................... 31

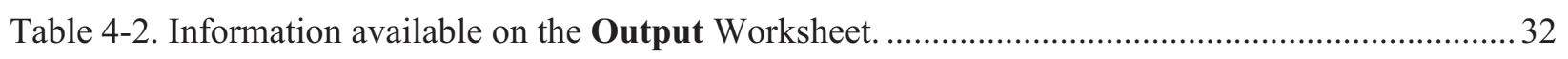

Table 5-1. Radioactive waste characterization based on decay heat and long-term radiotoxicity

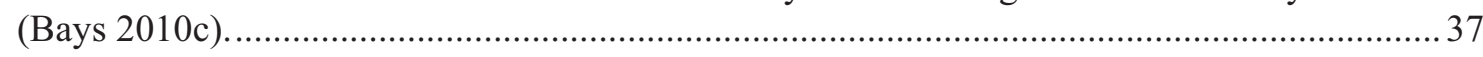

Table A1. FIT 1.0 Working-Value Separation Factors for UREX+1a Separation. ................................... 46

Table A2. FIT 2.0 Working-Value Separation Factors for UREX+1a Separation. ................................... 47 
Table A3. FIT 1.0 Working-Value Separation Factors for Electrochemical Separation. ..........................48

Table A4. FIT 2.0 Working-Value Separation Factors for Electrochemical Separation. .........................49

Table A5. FIT 1.0 Working-Value Separation Factors for AIROX. .....................................................5 50

Table A6. FIT 2.0 Working-Value Separation Factors for AIROX. ...................................................51

Table A7. FIT 1.0 Working-Value Separation Factors for Melt Refining...........................................5 52

Table A8. FIT 2.0 Working-Value Separation Factors for Melt Refining.............................................5 53

Table A9. FIT 2.0 Working-Value Separation Factors for PUREX....................................................... 54

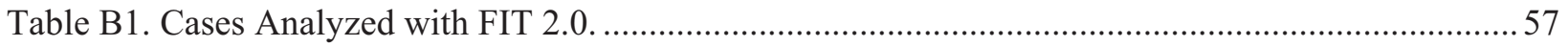

Table B2. Estimates of Fuel Impurities for which no oxide fuel limit exists (UREX+1 separation of both $\mathrm{UOX}$ and $\mathrm{FR}$ at $\mathrm{CR}=0.50)$. 64

Table B3. Estimates of fuel impurities for which no metal fuel limit exists (UREX +1 separation of $\mathrm{UOX}$ and electrochemical separation of $\mathrm{FR}$ at $\mathrm{CR}=0.50$ ). 


\section{ACRONYMS}

\begin{tabular}{|c|c|}
\hline AIROX & Atomics International Reduction Oxidation \\
\hline at $\%$ & atomic percent \\
\hline $\mathrm{Bk}$ & Berkelium \\
\hline BSG & Borosilicate glass \\
\hline $\mathrm{C}$ & carbon \\
\hline $\mathrm{Cd}$ & cadmium \\
\hline $\mathrm{Cf}$ & californium \\
\hline CFR & Code of Federal Regulations \\
\hline $\mathrm{Ci}$ & curie \\
\hline COEX & Co-extraction (of uranium and plutonium) \\
\hline CR & transuranic conversion ratio \\
\hline DOE & Department of Energy \\
\hline DOT & Department of Transportation \\
\hline DPL & Decision Programming Language \\
\hline DSARR & Dynamic Systems Analysis Report for Nuclear Fuel Recycle \\
\hline DU & depleted uranium \\
\hline Echem & electro-chemical \\
\hline EU & enriched uranium \\
\hline FCF & Fuel Conditioning Facility \\
\hline FCR\&D & Fuel Cycle R\&D, component of FCT program \\
\hline FCT & Fuel Cycle Technology program \\
\hline FFP & fraction of fission product \\
\hline FIT & Fuel-cycle Integration and Tradeoffs \\
\hline FP & fission product \\
\hline FPEX & Fission Product Extraction \\
\hline FR & fast reactor \\
\hline FY & Fiscal Year \\
\hline GNEP & Global Nuclear Energy Partnership \\
\hline Gr & group - one of 18 columns in the Periodic Table \\
\hline GTCC & Greater-Than-Class C \\
\hline HEU & highly enriched uranium \\
\hline HEPA & high efficiency particular air, a type of high-efficiency air filter \\
\hline
\end{tabular}




\begin{tabular}{|c|c|}
\hline HLW & high-level waste \\
\hline $\mathrm{HM}$ & heavy metal (thorium, protactinium, uranium, or transuranics) \\
\hline HTGR & High Temperature Gas Reactor \\
\hline HWR & Heavy Water Reactor \\
\hline $\mathrm{iHM}$ & initial heavy metal, the heavy metal content prior to irradiation of fresh fuel \\
\hline IMF & Inert Matrix Fuel \\
\hline INL & Idaho National Laboratory \\
\hline IWMS & Integrated Waste Management Strategy \\
\hline LEU & lowly enriched uranium \\
\hline LLW & low-level waste \\
\hline LWR & light-water reactor \\
\hline MLLW & mixed low-level waste \\
\hline MOX & mixed oxide fuel \\
\hline MW & megawatt \\
\hline MWth & megawatt thermal \\
\hline MWe & megawatt electric \\
\hline NA & Not applicable \\
\hline NE & nuclear energy \\
\hline NUEX & Neptunium (and Plutonium) extraction \\
\hline NU & natural uranium \\
\hline ppm & parts per million \\
\hline $\mathrm{Pu}$ & plutonium \\
\hline PUREX & Plutonium Uranium Reduction Extraction \\
\hline $\mathrm{R} \& \mathrm{D}$ & research and development \\
\hline $\mathrm{Rh}$ & rhodium \\
\hline $\mathrm{Ru}$ & ruthenium \\
\hline RU & recovered uranium \\
\hline SFR & Sweden Final Repository for radioactive operational waste, began operation in 1988 \\
\hline SNF & Spent Nuclear Fuel \\
\hline SNM & special nuclear material \\
\hline $\mathrm{Si}$ & silicon \\
\hline $\mathrm{SiC}$ & silicon carbide \\
\hline $\mathrm{Sr}$ & strontium \\
\hline TALSPEAK & $\begin{array}{l}\text { Trivalent Actinide Lanthanide Separation by Phosphoric Extractants and Aqueous } \\
\text { Komplexes }\end{array}$ \\
\hline
\end{tabular}




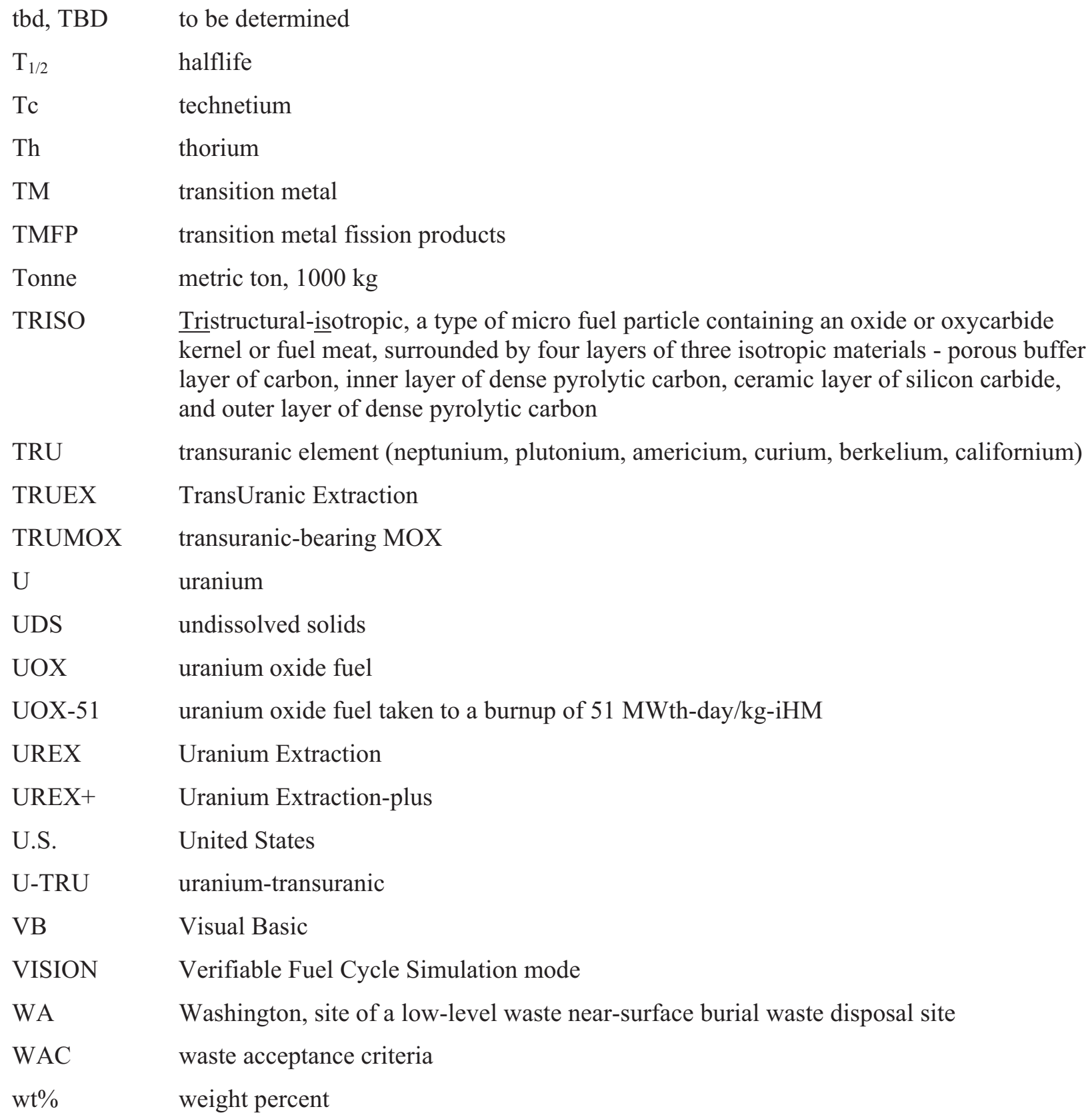





\section{SYSTEM ANALYSIS CAMPAIGN SEPARATION CAMPAIGN FUELS CAMPAIGN THE FIT 2.0 MODEL}

\section{OVERVIEW}

The system losses study started in FY2009 [Shropshire2009] and continued through FY2010 [Piet2010a]. It became necessary to create a model for the team to use to (a) permit a systematic examination of the chemical behavior of a fuel cycle and (b) analyze cases. The FY2009 exploratory analysis was limited to equilibrium analysis of the fast reactor recycling loop at transuranic conversion ratio of 0.5 , assuming incoming uranium and used LWR UOX-51 transuranic (TRU) streams were pure. In essence, the only specific impurities in fuel that received much attention were the lanthanides. In FY2010, it became clear that an analytical tool was required to consider a wider range of types of impurities and a wider range of technology options because the program was no longer focused on fast reactors fueled by used TRU from uranium oxide fuels. That model is called FIT, Fuel-cycle Integration and Tradeoffs. This report describes that model and how to use it.

Neither the separation factors nor the working fuel impurity limits used here are in any sense formal or final. Both are subject to R\&D results and analysis. Indeed, one purpose of FIT is to assist in identifying where working values come into problems and some of the impacts from different values.

This report documents the model and updated illustrative results. The FY2010 system losses report [Piet2010a] provides original results and more of the basic observations gained from creating and using the model.

The changes from FIT 1.0 to FIT 2.0 are as follows:

- FIT 2.0 calculates each individual element, whereas FIT 1.0 grouped chemically similar elements, e.g., all the halogens together. The problem with the grouping approach is that "chemically similar" depends on what processes are involved in a given analysis.

- Like FIT 1.0, FIT 2.0 adjusts the input fuel recipe (U versus TRU ratio) via 1-group cross sections to match the $\mathrm{k}$ of an original fuel recipe. FIT 2.0's adjustment now uses cross sections for hundreds of fission product isotopes, providing a better approximation. FIT 1.0 used lumped cross sections for groups of elements.

- Like FIT 1.0, FIT 2.0 calculates the actinide portion of the output fuel composition via the MrTau depletion model.[Alfonsi2011] FIT 1.0 obtained fission products increments from the original unadjusted fuel recipe. FIT 2.0 obtains fission product output from an update of MrTau, except where MrTau's results are not yet trustworthy (determined by a built-in test in FIT). Outside of the FIT task, separate funding will provide an update of MrTau that is expected to estimate more fission products. If so, it will simply replace the current MrTau and FIT will automatically adjust fewer isotopes via the trustworthy test.

- Like FIT 1.0, FIT 2.0 does not provide for calculation of non-fission product activation products, e.g., Co60 from Co59. But, it does track the mass of each non-fission product element, whereas FIT 1.0 did not. 
- More user-inputs have been moved to the "Control" worksheet. The user will typically only need go to other worksheets when inputting new separation matrices or input/output fuel recipes.

- The choice of separation matrices now include PUREX and a blank for users to modify without having to cannibalize the supplied UREX +1 , electrochemical, AIROX, and melt refining matrices. PUREX was added to address a quick-response question from DOE.

- The model outputs have been expanded to two tabs and provide more information than was provided in FIT 1.0. One output tab ("Output") shows key parameters (heat, gamma, neutron, radiotoxicity, mass, and volume) for each output waste stream, fuel blending fractions, reactor burnup, and reactor power, for each recycle iteration. The other output tab ("Output2") shows, for each iteration, elemental and isotopic mass flows through the model from separations-1 through fuel fabrication and reactor and separations-2 (or to waste streams).

- The working-value separation matrices have been updated. Grouped elements have been divided into individual elements, see Appendix A. As new information or estimates have been provided by Separations Campaign researchers or developed from reviews of prior literature, some separation factors have been updated.

- The FY10 calculations for the losses study [Piet2010b] have been updated, see Appendix B.

- Illustrative waste results are in Appendix C.

\subsection{Purpose}

FIT is a method to analyze different fuel cycles using common bases; in particular, to determine how changes in one part of a fuel cycle (say, fuel burnup, cooling, or separation efficiencies) affect other parts of the fuel cycle. FIT provides the following:

- Rough estimate of physics and mass balance feasibility of combinations of technologies. If feasibility is an issue, it provides an estimate of how performance would have to change to achieve feasibility.

- Estimate of impurities in fuel and impurities in waste as function of separation performance, fuel fabrication, reactor, uranium source, etc.

A different way to describe the purpose of FIT is as a management, qualitative, and quantitative tool to integrate technical information in the FCR\&D program.

\subsection{Structure}

Figure 1-1 illustrates the basic mass flows. It is the simplest framework on which we could base our analysis. Several user-defined inputs were fixed for the initial analysis - technologies and parameter ranges for which we had the most knowledge and for which individual parts of the calculation could best be validated. The incoming used fuel is always LWR UOX-51 in this report; users can input a different fuel. Separation of used UOX-51 provides the feed to start a recycle loop with a fast reactor, which is always a fast reactor with a transuranic conversion ratio of 0.50 in this report. Users can change the reactor in the recycle loop with some limitations described below. 


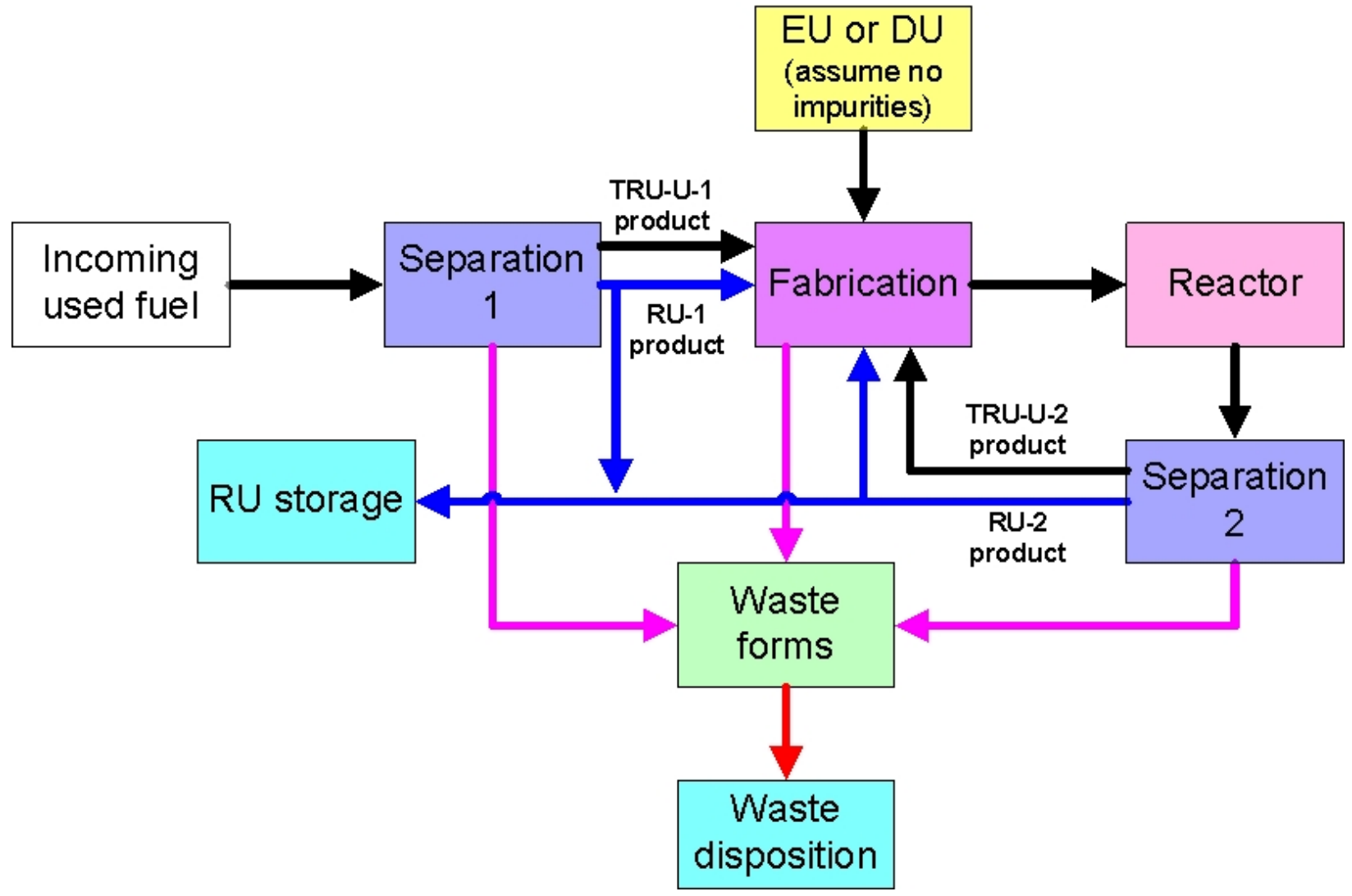

Figure 1-1. Basic mass flows; FIT 2.0 does not yet address EU feed as an option.

For the first recycle iteration (recycle-1), there are only the streams from incoming used fuel via separation-1. There is no mass flow yet from separation-2. For subsequent recycle streams, the TRU-U-1 product mass flow from separation-1 remains as before and the TRU-U-2 product mass from separation-2 from the previous iteration is added to create a combined TRU-U product stream. FIT uses a single set of separation factors for the entire suite of technologies that may be combined together. However, for the specific case of UREX +1 , the separation parameters for UREX+1 are calculated in FIT from inputs for the individual separation steps.

The user selects whether to use RU-1, RU-2, or DU to blend with this combined TRU-U product stream. (The current model assumes an adequate supply of whichever source of uranium is used.). The model estimates the required ratio of TRU-U product to $U$ feed for that recycle's iteration. Since the TRU-U product can contain uranium, and the RU streams will typically contain some TRU impurity, the ratio of TRU-U product to $U$ product is not the same as the chemical TRU:U ratio in the final blended product.

From a mass flow standpoint, there are two key things that occur. The first thing is the accumulation of impurities, unless the user has set both separation-1 and separation-2 to put no impurities in the TRU-U and $U$ streams. The second thing is the ratio of TRU:U. Separation options vary in their ability to separate TRU from U and this has major implications for FIT simulations. Consider that used LWR UOX fuel is $1.3 \%$ TRU and $93 \% \mathrm{U}$ and fast reactor fuel at a TRU conversion ratio of 0.5 is $30 \%$ TRU and $70 \%$ U. So, $96.7 \%$ of the $U$ in the $1.3 \%$-TRU/93\%-U output must be removed to create a $30 \% / 70 \%$ blend, i.e., only $3.3 \%$ of the $U$ can be kept with the TRU in this case. At one extreme of TRU:U controllability is aqueous separation options such as UREX+1 that can separate $99+\%$ of TRU from U. At the other extreme are some minimum fuel treatment options such as melt refining and AIROX, which 
cannot separate TRU from U. Thus, melt refining and AIROX are incapable of directly making fast reactor fuel from used LWR-UOX.

Electrochemical separation is between these extremes. The electrochemical separation parameters we have set in the model, which are user-changeable, were set to allow fast reactor fuel recycling with a high degree of uranium kept with the TRU to make the material less "attractive" from a proliferation resistance viewpoint. (50\%TRU/50\% U product from used fuel that is $18 \% \mathrm{TRU}-63 \% \mathrm{U}-9 \% \mathrm{FP}-10 \% \mathrm{Zr}$ gave a separation partition of $28 \%$ of the $U$ to the TRU-U product and $71 \%$ of the $U$ to RU. $28 \%$ retention of $U$ with TRU would make it impossible to make 30\%TRU/70\% U fuel from used LWR UOX with electrochemical separation.) We are not sure of the full range of the product composition and TRU:U separation, but researchers have produced TRU:U that is $80 \%$ TRU in a liquid cadmium cathode test.

Use of AIROX or other minimum fuel treatment separation options will leave a lot of fission products in the input fuel fabrication stream that may be removed in either melting (metal) or sintering (oxide) that are technically HLW. In this sense the minimum fuel treatment separations approach is just moving separations to the fuel fabrication processes.

Figure 1-2 shows a preliminary assessment of choices (green) and information flows (red) on top of the mass flows (black). Team discussion made it obvious that no two people viewed the information steps the same (i.e., what decisions lead to what outcomes). That realization generated the need for a "solver" or "optimizer" that will be able to use the mass flow engine from different perspectives. That solver does not yet exist. 


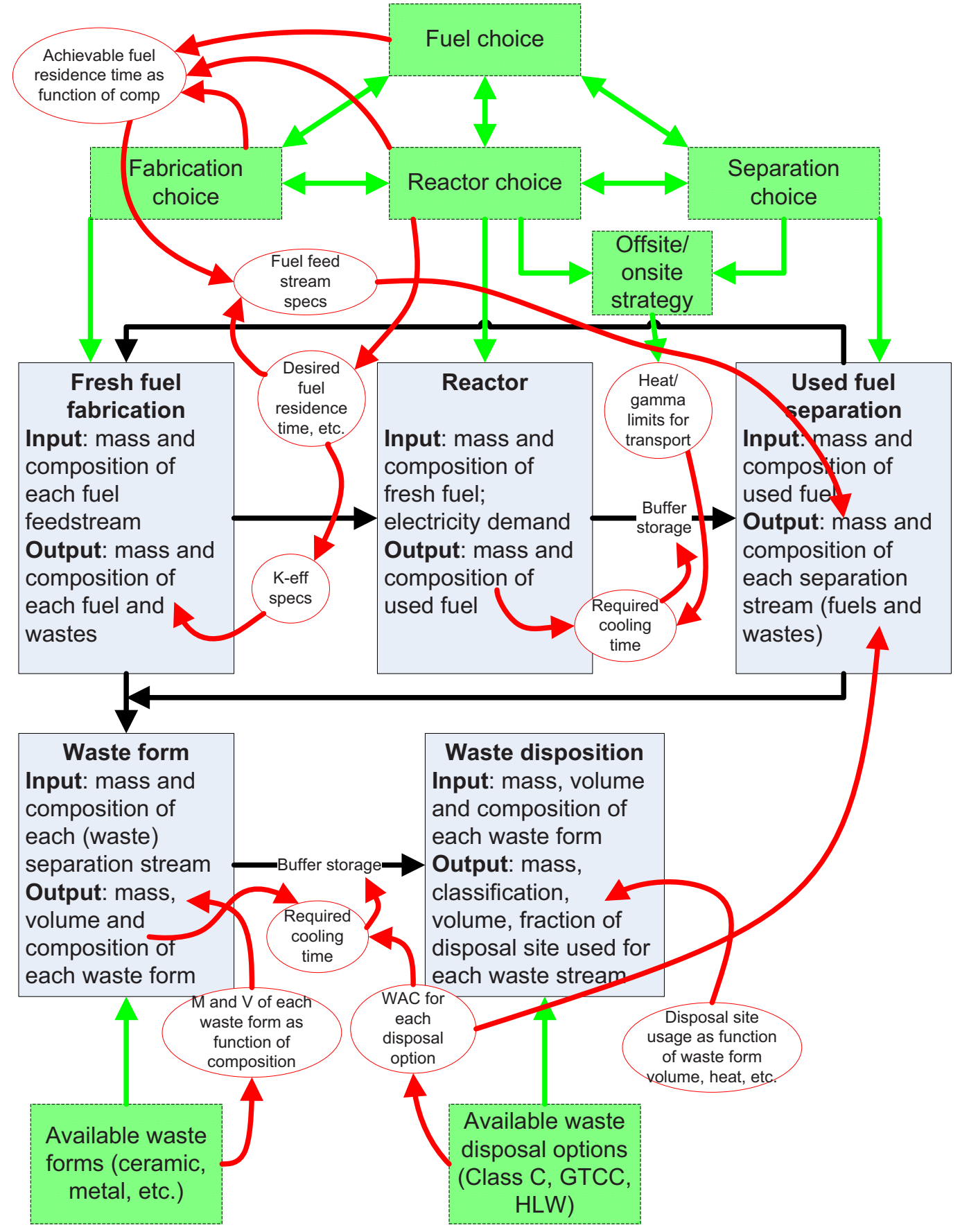

Figure 1-2. Technological choices (green) and information flows (red) overlaying mass flows (black).

\subsection{Limitations and Assumptions}

Users should understand the following limitations and assumptions.

\subsubsection{Physics}

FIT uses "reference" fuel compositions that must be calculated in some other fashion, such as those in the Transmutation Library [Piet2010a]. The model needs two fuel compositions - that of the incoming 
stream and that for the reactor in the recycle loop. The composition of the incoming stream is used, as is. FIT adjusts the composition of the reference fuel in the recycle loop according to what happens in the simulation.

The blending calculation in MrTauWinery to make the fuel in the recycle loop requires that the " $\mathrm{k}$ " of the fuel composition to be made must equal to the " $k$ " of the original "reference" fuel, with the implication that the resulting fuel could have the same fuel residence time - from the physics perspective.

1-group cross sections are used to make the input fuel composition adjustment noted above. This occurs in MrTauWinery, combining methods described elsewhere.[Yee2008, Bays2009, Bays2010a, Bays2010b] As impurities appear or fuel isotope compositions change criticality from the feedstock assumed in the "reference" fuel calculations, the model adjusts the TRU:U radio accordingly.

- $\quad$ FIT does not have the option of using enriched uranium as one of the feeds to the recycle loop.

MrTauWinery is also used to calculate the recycle loop's reactor discharge composition according to the adjusted input composition.

- Adjustment by adding impurities in one or more feeds.

- Adjustment of the TRU:U ratio as noted above.

- Adjustment by impurities that may occur during fuel fabrication.

MrTauWinery calls the MrTau-Fortran executable, which is essentially a simplified version of ORIGEN equations and is done by the Fortran executable invoked by the MrTauWinery Excel2007 file.

Radionuclide decay is accounted for in various storage steps in the FIT model. FIT uses a simplified decay calculation. Most of the tracked radionuclides that have a half-life of greater than 4000 years are considered stable for the purposes of this model. In FIT, the user can specify a decay time for each of the storage steps. Entering a number storage time of greater than 400 years will result in some significant error in the decay calculation. Therefore, FIT is limited to calculating storage durations of less than 400 years.

\subsubsection{Feed stocks}

The default incoming used fuel composition is LWR UOX at $51 \mathrm{MWth}-\mathrm{day} / \mathrm{kg}$-iHM burnup. The user can change the aging time from 0 to 30 years on the Control worksheet in FIT. The user can change the fuel composition by substituting new data on the worksheet UOX-51 raw data, but in the exact same format and without changing the worksheet name.

There are four data columns in the MrTauWinery Excel2007 file allowing compositions for the recycle loop's reactor fuel. These are as follows:

- Fast reactor, metal fuel, $\mathrm{CR}=0.5$, startup composition (case 14)

- Fast reactor, oxide fuel, $\mathrm{CR}=0.5$, startup composition (case 15)

- Fast reactor, metal fuel, $\mathrm{CR}=0.5$, equilibrium composition (case 16)

- Fast reactor, oxide fuel, $\mathrm{CR}=0.5$, equilibrium composition (case 17)

These can be changed, but the model assumes that cases 14 and 16 are metal fuel and 15 and 17 are oxide fuel. That assumption determines which fuel fabrication models (metal or oxide) are used. 
For example, any U/TRU fast reactor case can be run with transuranic conversion ratio $(\mathrm{CR}) \leq 1$, by changing the recipes in the MrTauWinery file as explained below. Simulations with CR $>1$ (i.e. breeder reactors) would require a model change that would allow the incoming used fuel through separation-1 to be turned off after the first iteration. That is, once used fuel is employed to start a fast breeder reactor recycling loop, incoming used fuel is no longer need (in contrast to $\mathrm{CR}<1$ ) and that flow needs to be turned off to allow FIT to simulate a breeder case.

RU-1 comes from separation-1; RU-2 comes from separation-2. The compositions are calculated in the model.

The composition of DU is set in the MrTauWinery Excel2007 file. The values there correspond to $0.2 \%$ tails ${ }^{\mathrm{a}}$ and no impurities. Users can change the values to match other assumptions.

The user selects on the Control worksheet whether to use RU-1, RU-2, or DU. We recommend RU-1 for the first recycle iteration (there is no RU-2 for recycle-1) and RU-2 for subsequent recycles, corresponding to keeping all the $U$ with TRU in fast reactor recycling. The supply of the selected source of uranium is unlimited in FIT 2.0. This is a fine assumption for non-breeder reactor cases as there is always excess uranium in the system.

\subsubsection{Separations}

The separation efficiencies are assumed static as the composition changes, e.g., as impurities accumulate. So, if $0.5 \%$ of the lanthanides are indicated as going into fuel, that percentage is constant regardless of how high the lanthanide impurity in the fuel may grow. Reality is undoubtedly more complex than this simplifying assumption.

The model has five separation data sets and one blank. The five sets are UREX $+1 \mathrm{a}$, electrochemical, AIROX, melt refining,[Piet2010b] and PUREX. These can be changed. These data are matrices. The rows are the isotopes, elements, and groups of elements tracked in FIT. The columns are the output products, both fuels and wastes. Each value tells the spreadsheet what fraction or percent of that isotope/element/group goes into that column's product.

Use of AIROX or other minimum fuel treatment separation options will leave a lot of fission products in the input fuel fabrication stream that may be removed in either melting (metal) or sintering (oxide) that are technically HLW. In this sense the minimum fuel treatment separations approach is just moving separations to the fuel fabrication processes.

Some data sources, particularly old ones, report some separation as $\sim 100 \%$ or "nil", referring to the amount retained in recycled TRU+U product versus waste. We interpret these to be $99.9 \%$ and $0.1 \%$ respectively. If separation data for an element are missing, we have typically done the following:

Use the most similar chemical element.

Use $99.9 \%$ retention in TRU+U product for gaseous elements or $0.1 \%$ for non-gaseous elements.

\subsubsection{Fuel fabrication}

There are no models included for recycle of materials for non-fuel use, e.g., lanthanides for use in solar or wind zirconium for new cladding, or graphite blocks.

a To calculate mass balanced and composition when uranium is enriched, one has to specify the U-235 content in both in the enriched product and in the residual depleted uranium. The former is determined by reactor physics. The latter is called "tails" and is based on economics. Common practice is in the range $0.2 \%$ to $0.3 \%$. We have been using $0.2 \%$; the user can input whatever they wish. 
The composition of fuel is not constrained by impurity limits. The model uses various inputs to calculate the level of impurities in fuel and in waste; the user has to determine if the levels of impurities are acceptable and, if not, what inputs must be changed to search for an acceptable combination of parameters.

Fuel impurity limits can be expressed as the limit of an impurity in finished fuel product, in the blended composition going into fuel fabrication, or in one or more of the feeds to be blended during fuel fabrication. Any of these are typically parts per million (ppm), but the (unstated) denominator basis varies (fuel, fuel feed, or a particular fuel feed). Note that the working Fuels Campaign limits are specified in terms of the TRU feedstock with four key assumptions.

1. The TRU feed stream is only TRU.

2. The uranium blended to make fuel is assumed chemically pure. Thus, the "DU feed" calculations best match the underlying Fuels Campaign assumptions.

3. The fast reactor has a TRU conversion ratio near 0.5. The conversion ratio determines the ratio of TRU:U.

4. No significant impurities enter during fuel fabrication itself.

Thus, for system losses study purposes, these had to be back-calculated to determine impurity limits on the final fuel product.

Fuel impurity limits for a given element or set of elements can arise from one or more of the following:

- Impact on fuel matrix performance during irradiation

- Impact on fuel - cladding (or coating) interaction during irradiation

- Impact on fuel fabrication

- Increase in neutron absorption (this is approximated in FIT)

- Displacement of fuel (this is not addressed in FIT because the team felt it would be easily adjusted for).

Many current Fuels impurity limits are groups of elements, some of which are fission products and some are not. Our available data on fuel composition only includes fission products.

The working Fuels Campaign impurity limits stem from consideration of what impurities might be present from mining, milling, prior processing, etc. - but not fission products that would be formed while in the reactor.

\subsubsection{Waste management}

Waste management is addressed in the model by tracking the masses of all materials separated from used fuel that are not recycled into new fuel. Waste streams generated during fuel fabrication are also tracked. Users can also track operations and maintenance wastes generated during separations, although operations and maintenance wastes created in other parts of the fuel cycle (the front end, initial fuel fabrication, the reactors) are not yet included in this model.

The waste streams are treated in the model so as to convert the waste stream into a waste form suitable for disposal. The waste forms used in the model are generally consistent with the recent studies of the Integrated Waste Management Strategy [IWMS, Gombert 2008], the Advanced Fuel Cycle Facility 
(AFCF) design [DOE 2007], and the Waste Form Campaign [Vienna 2010]. This results in waste classification (or at least ultimate waste disposition) presumptions regarding what waste form is required or desired for which waste disposition.

The user may rely on the waste classification interpretations used in the referenced IWMS, AFCF design, and Waste Form Campaign studies that are based on minimal variation from how current waste policies and regulations are interpreted. Or, the user may use the characteristics of the waste streams to make assessments about how some waste streams could be managed. In some cases, assumptions used in the model may not be consistent with some interpretations of current, source-based waste management policy and regulations. In some cases, the waste form may be more robust than required if that waste stream is managed according to its hazard characteristics. Most important, we track and report the waste characteristics and the presumed waste forms, so the user can, if she desires, assess how the waste forms can be appropriately managed. The model includes various options for placing different waste streams into different optional waste forms.

We also presume in the model that waste mass and volume reduction will be important. So, especially for the high-volume and high-mass wastes from separations process operations and maintenance, we presume the use of thermal treatment to not only convert the waste stream to a robust waste form that should meet storage, transportation, and disposal requirements, but also to significantly reduce the waste form volume and mass compared to other options, such as grouting. Reducing the volume and mass of the large amounts of operating and maintenance wastes can show stakeholders how closed fuel cycle options not only recover and recycle valuable fissile and fertile material from used fuel, but also how these options use state of the art technologies to minimize radioactive wastes generated during fuel recycling.

\subsubsection{High-Level Waste}

The FIT model describes each waste stream based on its composition, heat, waste form volume and mass, radiotoxicity, and emissions of gamma and neutron radiation. In addition, the model assumes that waste streams designed to contain long-lived radionuclides, with half-lives greater than about 100 years, would be high level waste. These waste streams are those designed to contain separated C-14, separated I-129, Tc-99 if it is separated, and waste streams that contain the remaining FPs. Waste streams designed to contain separated H-3 and Kr-85, and waste streams such as operations and maintenance waste that are just contaminated with some of these long-lived isotopes, are not automatically classified as HLW. The HLW streams are separately tracked and are also summed and placed into a "HLW" category.

Note that FIT inherently assesses mass flows and mass composition, thus all the mass flows (including hypothetical HLW) are assessed from a compositional standpoint, which may or may not align with legal definitions.

\subsubsection{Low-Level Waste}

The classification of LLW that is Class C or Greater Than class C is estimated in this model using federal regulations found in 10 CFR 61. For simplicity, no distinction is attempted between waste that might be Class A, B, or C. The distinction between Class C and GTCC is made to at least determine which waste streams, masses, and volumes might be disposable in near-surface LLW disposal sites versus those that would require isolation from the environment for geological timeframes.

Tables 1 and 2 in 10 CFR 61 only include 12 isotopes plus alpha emitting transuranic nuclides with halflives greater than 5 years. Many of the isotopes in used fuel are not in these tables. Determining LLW classification without considering these other isotopes could result in determinations of Class C or less for waste streams that contain higher levels of specific activity than were intended. 
Analyses done by other researchers have used the same approach of 10 CFR 61 to estimate specific activity limits for other isotopes not specifically listed in 40 CFR 61 (Fetter 1988, Fetter 1990). These prior analyses also corrected some minor errors in the 40 CFR 61 calculations. The FIT model uses these specific activity limits to estimate, using the more complete listing of specific activity limits, the classification (Class C or less versus GTCC) for streams that are thought to be considered LLW. The user is warned here that, because of the inclusion of other radionuclides that are not in 10 CFR 61, and because of a few minor corrections made by Fetter, et al in the prior analyses, the LLW class determinations in the FIT model may not match a determination made based only on 10 CFR 61. While these determinations in the FIT model may not match determinations based on the current 10 CFR 61, we think they are more appropriate for the intended uses of the FIT model because they do not excluded the specific activity of radionuclides not in the current 10 CFR 61.

Waste streams considered to be LLW (or those that could have levels of radionuclides with activity levels within LLW Class C limits after a reasonable decay time period of less than 300 years) include some operating and maintenance waste streams, and waste streams designed to contain separated C-14, I-129, $\mathrm{Kr}-85$, and $\mathrm{Cs} / \mathrm{Sr}$. We recognize that this approach potentially diverges with how current waste policy is defined, but this approach enables the documentation and evaluation within the FIT model of those separations processes such as UREX + separations, in which the separation of these short-lived radionuclides is possible. Regardless of this approach, the FIT model provides the waste stream characterization information, and users have the option to determine how these waste streams might be classified or disposed.

At this time there is considerable uncertainty in waste packaging assumptions. FIT 2.0 does not yet include waste volumes based on waste packaging and void space in the output tables, to avoid potential confusion caused by waste packaging assumptions on the actual volume of the waste forms. But, the framework in the model includes placeholders for waste packaging and void space assumptions should the user want to include those calculations. Assumptions for packaging can be changed by the user. 


\section{INSTALLATION AND OPERATION}

Installing FIT 2.0 requires a PC running Microsoft Excel2007. Perform the following steps to install FIT 2.0:

1. Create a folder C:IMRTAU $\backslash V 2.0$

2. Copy the various FIT 2.0 files to that folder.

3. Be sure that the SOLVER add-in is installed in your PC's copy of Excel2007. To check if SOLVER is installed, go to the windows office icon on the upper left corner of Excel. At the bottom, click on "Excel options". On the left side pane, click on "Add-Ins." If SOLVER has been installed, it will be in the list under Active Application Add-Ins. If not, go the bottom, manage "Excel Add-Ins", and click "Go." Yet another box comes up, listing available Add-Ins. Put a checkmark next to Solver Add-In, and then click "OK".

4. Enable macros either permanently or every time you use FIT.

One can have multiple versions of the FIT and MrTauWinery files in that directory; but the user must input the name of the MrTauWinery file to be used in the upper left corner of the "Control" worksheet in the FIT file so that the FIT file knows which MrTauWinery file to use.

Simulations are executed from the Control worksheet. Select parameters in blue and radio buttons to set up simulation. Run the first iteration by pressing the Run first iteration button. Change any necessary parameters, and enter the number of subsequent iterations desired (n). Then press Run iteration loop to execute the iterations 2 through $\mathrm{n}$ (where $\mathrm{n}$ currently has a maximum value of 18).

FIT requires a PC with Excel2007, with the "SOLVER" add-in installed. Installation (Chapter 2) results in three key files on your PC, together with various auxiliary files that the typical user will not need to consider:

1. FIT Excel2007 file

- Current version is FIT 2.0.xlsm

2. MrTauWinery Excel2007 file

- Current version is MrTauWinery_v2.0.xlsm

3. MrTau.exe Fortran executable file (this does not require a Fortran compiler)

- Current version is MRTAUc.exe

These files must be in the following directory

C: $\backslash$ MRTAU $\backslash V 2.0$

One can have multiple versions of the FIT and MrTauWinery files in that directory; but the user must input the name of the MrTauWinery file to be used in the upper left corner of the "Control" worksheet in the FIT file so that the FIT file knows which MrTauWinery file to use.

The FIT file controls everything. It performs all calculations (and associated data) other than the physics and blending calculations, i.e., the fraction of TRU-U feed versus uranium feed. FIT calls the MrTauWinery Excel2007 file for blending before fuel fabrication. After fuel fabrication, it again calls the 
MrTauWinery Excel2007 file, which this time uses the MrTau-Fortran code for a depletion calculation to get the actinide part of the output composition.

It calls and links to the MrTauWinery Excel2007 file, which itself calls the Fortran executable. MrTau is a standalone physics tool described elsewhere.[Bays2010a, Bays2010b, Alfonsi2011] Users only need to open the MrTauWinery Excel2007 file if they wish to add or change physics data or change the method of 1-group cross sections that control the blending ratios between separation-1, separation-2, and DU.

If a new version of MrTauWinery Excel2007 or MrTau-Fortran is created, it can be placed in the MRTAU/V2.0 directory (created during installation). When FIT is run, the user simply gives it the new name of the Excel2007 file.

Some notes:

- The bottom right corner of FIT will tell the user what it is currently being done during execution.

- FIT (including MrTauWinery and MrTau-Fortran) 5 minutes per recycle iteration.

- The more Excel files open, the lower the FIT will run.

- Attempting to examine or otherwise interfere with FIT or MrTauWinery as their macros are executing is likely to cause the execution to fail, in which case you need to start over. This is particularly undesirable when running multiple recycle iterations.

- You must enable macros. 


\section{INPUTS AND DESCRIPTION OF EACH WORKSHEET}

Start by opening the FIT file and going to the left-most worksheet, called Control. With the exception of physics data and reference input/output composition data, all data and settings are in the FIT Excel2007 file, which is described next. The physics data and input/output composition options are in the MrTauWinery Excel2007 file, which is described after FIT.

\subsection{In the FIT Excel2007 File}

The top part of the Control worksheet is the main control panel, where the basic settings are selected and the user runs either recycle-1 (the first iteration) or a designated number of iterations after recycle 1.

The bottom part of the Control worksheet is a set of navigation buttons (Table 3-1) that takes the user to the indicated worksheets. One can of course also go to those worksheets by selecting the worksheet at the bottom of the Excel2007 file.

Table 3-1. Navigation choices on Control Worksheet (color coded in the FIT Excel2007 file).

\begin{tabular}{|c|c|c|c|c|c|c|c|c|}
\hline General & $\begin{array}{l}\text { Separation1 } \\
\text { related } \\
\text { calculations }\end{array}$ & $\begin{array}{c}\text { Fuel Recipe } \\
\text { adjustment } \\
\text { calculations }\end{array}$ & $\begin{array}{l}\text { Oxide fuel } \\
\text { fabrication }\end{array}$ & $\begin{array}{l}\text { Metal fuel } \\
\text { fabrication }\end{array}$ & $\begin{array}{l}\text { Reactor/input- } \\
\text { output }\end{array}$ & $\begin{array}{l}\text { Separation2 } \\
\text { related } \\
\text { calculations }\end{array}$ & $\begin{array}{c}\text { Waste } \\
\text { processing } \\
\text { calculation }\end{array}$ & $\begin{array}{c}\text { Waste } \\
\text { disposal } \\
\text { calculations }\end{array}$ \\
\hline Control & $\begin{array}{l}\text { UOX-51 } \\
\text { raw data }\end{array}$ & $\begin{array}{l}\text { Fuel Input } \\
\text { Adjustment }\end{array}$ & Inputs & Inputs & $\begin{array}{l}\text { Reactor } \\
\text { output }\end{array}$ & $\begin{array}{l}\text { Separation2 } \\
\text { calculation }\end{array}$ & Inputs & $\begin{array}{l}\text { Heat and } \\
\text { dose data }\end{array}$ \\
\hline Output & $\begin{array}{l}\text { Input for } \\
\text { Separations } \\
1\end{array}$ & & $\begin{array}{l}\text { Isotopic } \\
\text { blending }\end{array}$ & $\begin{array}{l}\text { Feed } \\
\text { preparation }\end{array}$ & $\begin{array}{l}\text { Reactor } \\
\text { storage }\end{array}$ & $\begin{array}{l}\text { Separation2 } \\
\text { storage }\end{array}$ & $\begin{array}{l}\text { Recovered } \\
\text { uranium }\end{array}$ & $\begin{array}{l}\text { Waste } \\
\text { disposition } \\
\text { selection }\end{array}$ \\
\hline Output2 & $\begin{array}{l}\text { UREX+1a } \\
\text { calculations }\end{array}$ & & $\begin{array}{l}\text { Manu- } \\
\text { facturing } \\
\text { process }\end{array}$ & $\begin{array}{l}\text { Manu- } \\
\text { facturing } \\
\text { process }\end{array}$ & & & Zeolite & $\begin{array}{l}\text { Waste } \\
\text { storage }\end{array}$ \\
\hline \multirow[t]{13}{*}{$\begin{array}{l}\text { Model } \\
\text { Flow }\end{array}$} & $\begin{array}{l}\text { Separation } \\
\text { matrices }\end{array}$ & & $\begin{array}{l}\text { Scrap } \\
\text { recovery } \\
\text { process }\end{array}$ & $\begin{array}{l}\text { Scrap } \\
\text { recovery } \\
\text { process }\end{array}$ & & & $\begin{array}{l}\text { Glass } \\
\text { bonded } \\
\text { zeolite }\end{array}$ & $\begin{array}{l}\text { Waste final } \\
\text { disposal } \\
\text { output }\end{array}$ \\
\hline & Separation1 & & QC testing & QC testing & & & $\begin{array}{l}\text { Lanthanide } \\
\text { glass }\end{array}$ & \\
\hline & $\begin{array}{l}\text { Separation1 } \\
\text { storage }\end{array}$ & & $\begin{array}{l}\text { Summary } \\
\text { output }\end{array}$ & $\begin{array}{l}\text { Summary } \\
\text { output }\end{array}$ & & & $\mathrm{Kr} / \mathrm{Xe}$ & \\
\hline & & & Fuel fabrica & on storage & & & $\mathrm{Cs} / \mathrm{Sr}$ & \\
\hline & & & & & & & $\begin{array}{l}\text { Metal alloy } \\
\text { ingot }\end{array}$ & \\
\hline & & & & & & & $\begin{array}{l}\text { Remainder } \\
\text { metal }\end{array}$ & \\
\hline & & & & & & & Grout & \\
\hline & & & & & & & $\begin{array}{l}\text { Solvents- } \\
\text { Liquids }\end{array}$ & \\
\hline & & & & & & & $\begin{array}{l}\text { Fuel } \\
\text { fabrication } \\
\text { wastes }\end{array}$ & \\
\hline & & & & & & & $\begin{array}{l}\text { Operational } \\
\text { wastes }\end{array}$ & \\
\hline & & & & & & & $\begin{array}{l}\text { HLW glass } \\
\text { output }\end{array}$ & \\
\hline & & & & & & & $\begin{array}{l}\text { HLW glass } \\
\text { input }\end{array}$ & \\
\hline & & & & & & & $\begin{array}{l}\text { HLW glass } \\
\text { calculations }\end{array}$ & \\
\hline
\end{tabular}




\subsubsection{Control}

First, make any data changes to this file and/or MrTauWinery Excel2007 file.

Second, make any changes to the settings on the Control worksheet.

- MRTAU filename: user types in the name of the MrTauWinery Excel2007 file you wish to use.

$\bigcirc \quad$ Default $=$ MrTauWinery_v2.0.xlsm

- If you want to change the composition of incoming fuel, go to worksheet UOX-51 raw data.

- Select Storage before Sep1, which is the storage time from when the incoming fuel was discharged from its reactor to when separation 1 occurs via a pull-down menu. A pulldown menu is used to force the user to select one of the time periods on the UOX-51 raw data worksheet.

- Number of iterations: input the integer number of iterations you wish FIT to calculate. It will generally not take many to cause the system's chemistry to either stabilize or terminate because the model cannot make acceptable fuel. To date, we have used 9, or 19 to be conservative. For example, 19 iterations plus the first iteration gives a total of 20 .

\section{- Separations 1}

- Select the separation technology matrix via a drop down list, options are UREX $+1 \mathrm{a}$, ECHEM, AIROX, melt refine, PUREX, user defined.

- Select the storage time from input used fuel (Sep1 storage): the number of years between separations 1 and when fuel is blended and inserted into the reactor. This can be any value up to a few hundred years.

- Determine if UDS goes to glass if you are using UREX+1. This applies to all use of UREX+1, either Sep1 or Sep2. The default is to have this unchecked. If it is selected, the undissolved solids (UDS) would be combined with the raffinate/residual in the HLW glass waste form. If it is unchecked, the UDS would then go into the metal alloy ingot waste form.

- Input the percent of UREX+1 separation stream that goes to UDS, $1 \%$ is the recommended value. This applies to all use of UREX+1, either Sep1 or Sep2. This allows the user to select what percent of the fuel meat (except for volatile fission products, noble gases, halogens, C-14, and H-3) becomes UDS for UREX+1a only

- Select the source of recycle material, use the first option (material from Separations 1) for the first recycle iteration and the second (material from both separations) for subsequent iterations.

- Select the source of uranium, use RU-1 or DU for the first recycle iteration and RU-2 or DU for subsequent iterations.

- Reactor: drop down list, options are

- Fast reactor, metal fuel, $\mathrm{CR}=0.5$, startup composition

- Fast reactor, oxide fuel, $\mathrm{CR}=0.5$, startup composition 
- Fast reactor, metal fuel, $\mathrm{CR}=0.5$, equilibrium composition

- Fast reactor, oxide fuel, $\mathrm{CR}=0.5$, equilibrium composition

- Rx storage: the number of years between reactor discharge and when fuel is enters separation 2 . This can be any value.

- Separations 2: drop down list, options are UREX+1a, ECHEM, AIROX, melt refine, PUREX, or user defined.

- Sep2 storage: the number of years between separations 2 and when fuel is blended and inserted into the reactor. This can be any value.

- Check if you want lanthanides to be combined with HLW glass, this applies to all separations (both sep1 and sep2). The default is to have this unchecked. If it is checked, the lanthanides would then be combined with the raffinate/residual in the HLW glass waste form. If it is unchecked the lanthanides would then go into a lanthanide glass waste form.

Third, run the calculation.

- For recycle 1, select Material from Separations 1 and click on Run first iteration.

- For recycle $>1$, select Material from both separations and click on Run iteration loop.

\subsubsection{Separation 1}

These worksheets provide the incoming material for the recycle loop and have several inputs the user may wish to review or change.

- To change the type of incoming fuel, the composition on the UOX-51 raw data worksheet must be changed.

- To change the aging of the incoming fuel (time from reactor discharge to input to separations1), use the worksheet Control.

- To change the separation efficiencies for electrochemical, AIROX, or melt refining, go to the worksheet Sep_Matrices.

- To change the separation efficiencies for UREX+1a, go to the UREX+1a worksheet.

- The default power, thermal efficiency, capacity factor, and burnup for the reactor providing its used fuel into separation 1 are given in cells P17 to P20. These parameters are the basis for calculating the mass flow into sep 1.

UOX-51 raw data contains the detailed isotopic data for LWR UOX-51. In FIT 2.0, if the user wants to change the incoming fuel type, these data must be replaced with the new fuel type. However, the name of the worksheet must not change and the exact format on this page must be maintained. In particular, a defined range "UOX_Table" must be unchanged.

Input_Sep1 prepares the feed stream into separation1. Of particular note is cell T2, which controls the length of time that the incoming feed material is aged. This is set on the Control worksheet. 
The worksheet UREX+1a calculates the separation factors for UREX+1a based on the split fractions from Candido Pereira in May 2010. Where separation factors are missing or 100\%, default values of $99.9 \%$ to desired product and $0.1 \%$ to waste are used in most cases.

The worksheet Sep_Matrices contains the matrices that take each tracked isotope or chemical element or group of chemical elements and provides the percentage that goes to each product or waste stream. The totals for each row must equal to $100 \%$, confirming that the input mass of each radionuclide is split among the different possible output streams, so that mass is lost or created.

- UREX+1 data are pulled from the worksheet UREX+1a.

- Electrochemical (echem) data are input here. Data in the file come from G. Teske.

- $\quad$ AIROX data are input here. Data in the file come from Christianson1999.

- Melt refine data are input here. Data in the file come from G. Teske.

- PUREX data are input here. Data in the model are adapted from the similar portions of the UREX+1 flowsheet.

Calc_Sep1 calculates the inventory going to each of the output separation streams based on the split factors in the worksheet Sep_Matrices and based on the user input of the selected separation process. The columns on the left bring in the reactor output stream. The user-selected options on the Control worksheet and the values on worksheets UREX_1a calculations and separation matrices are copied to the block on this page called "separation 1". The separation matrix then produces the separations output mass streams further to the right. Cell J34 should read "Mass is balanced". If not, there is an error with the separation matrix.

Sep1_Storage calculates the input spent fuel inventory change (due to decay and in-growth) for the specified number of years of storage between separations and fuel fabrication. There are three blocks of data, but "U-TRU product 2" is not currently being used. "From Sep 1" brings into the page the output from separation-2. Cell M2 displays the numbers of years of storage between separation 2 and fuel blend/reactor input, this value is input on the Control worksheet, not here! The length of storage is used to calculate the aged composition, which is then used in the blending and fuel fabrication calculations.

\subsubsection{Fuel input adjustment}

There no user inputs on this worksheets.

This worksheet calculates what goes to the fuel input adjustment calculation in the MrTauWinery Excel2007 file. If the user has selected Material from Separations 1 on the Control worksheet, it simply uses the mass flow from separations1. If the user has selected Material from both separations, it adds the mass flows from separations 1 and separations2. The input composition adjustment in MrTauWinery requires mass fractions, so mass fractions are calculated from the total mass flow. The mass fractions returning from MrTauWinery are then converted into moles as input to fuel fabrication.

\subsubsection{Oxide fuel fabrication}

Reject rate projections are input on the Inputs_O worksheet, i.e., the percent of input mass flow that leads to reject product at each step in fuel fabrication. In the other worksheets the fraction of the reject rate going into various streams (recycle, recovery, container waste, HEPA waste, etc) is a user input.

More information on the various steps in fuel fabrication can be found in the system losses study report. 
The Inputs_O worksheet is the start of the oxide fuel submodel within FIT, provided by Eric Shaber and Melissa Teague. However, the original submodel's calculation of the TRU:U ratio is over-ridden because that is calculated in FIT on the Fuel Input Adj worksheet. Column V has the total reject rate for the various steps in the fuel fabrication process, which can be changed by a knowledgeable user.

Feed Prep calculates the preparation stream.

Iso Blend_O calculates stoichiometric adjustment from making metal nitrate and later denitration.

Process_O has the details of fuel fabrication.

QC Test_O details quality control testing of fuel.

Recovery_O describes what in-processes scrap materials are recovered and sent back to feed preparation.

Summary_o provides summary information for metal fuel fabrication. Information and masses proceed to worksheet Fuel Fab_Storage. The fabrication mass balances provides fuel rod data but not fuel element data as they are reactor specific. The fuels output data must be adjusted to get actual fuel elements based on the reactor defined in the fuel cycle.

\subsubsection{Metal fuel fabrication}

Reject rate projections are input on the Inputs worksheet, i.e., the percent of input mass flow that leads to reject product at each step in fuel fabrication. In the other worksheets the fraction of the reject rate going into various streams (recycle, recovery, container waste, HEPA waste, etc) is a user input.

More information on the various steps in fuel fabrication can be found in the system losses study report.

The Inputs worksheet is the start of the metal fuel submodel within FIT, provided by Eric Shaber and Melissa Teague. However, the original submodel's calculation of the TRU:U ratio is over-ridden because that is calculated in FIT on the Fuel Input Adj worksheet. Column AA has the total reject rate for the various steps in the fuel fabrication process, which can be changed by a knowledgeable user.

Feed Prep calculates the preparation stream.

Process has the details of fuel fabrication.

QC Test details quality control testing of fuel.

Recovery describes what in-processes scrap materials are recovered and sent back to feed preparation.

Summary provides summary information for metal fuel fabrication. Information and masses proceed to worksheet Fuel Fab_Storage. The fabrication mass balance provides fuel rod data but not fuel element data as they are reactor specific. The fuels output data must be adjusted to get actual fuel elements based on the reactor defined in the fuel cycle.

\subsubsection{Fuel fab storage (the last step before reactor input)}

There no user inputs on this worksheets.

For metal fuels (cases 14 or 16 in MrTauWinery), this worksheet draws from metal fuel fabrication. For oxide fuels (cases 15 or 17 in MrTauWinery), this worksheet draws from oxide fuel fabrication.

Fuel Fab_Storage calculates the reactor input fuel composition for the specified number of years of storage after fuel fabrication. Cell K2 has the number of years of storage between fuel fabrication and 
insertion into the reactor. The years of decay is set to a default of zero years in this version of FIT so that the model does not have to perform another fuel input adjustment (as discussed in 3.1.3). This is assuming that the fuel is fabricated just in time to be inserted into the reactor. (A delay of a month or so would make no significant difference. A delay of a year would be significant, in which case in the current model a year would have to be added to the time lag between separation and fuel fabrication.) The length of storage is used to calculate the composition that goes into the reactor, which is then used in

Reactor_Output.

\subsubsection{Reactor}

There are two reasons why the user may wish to examine these worksheets, especially Reactor_Output: (1) use of a new target impurity-free recipe and (2) adjust the trustworthy test on MrTau results.

Reactor_Output brings the output composition as calculated by MrTauWinery Excel2007 file back into the FIT spreadsheet and reassembles the total mass reactor output mass flow. Currently, the output composition is assembled as follows.

- The actinides ( $\mathrm{kg} / \mathrm{yr})$ are calculated by the output mass fractions from MrTauWinery times the total mass of actinides from worksheet Fuel Fab_Storage. Note that the mass fraction sent to MrTauWinery is 1.00 . MrTauWinery then returns a total mass fraction that is typically greater than 1.00 , the difference is caused by numerical instabilities in fission product calculations in the current version of MrTau-Fortran.

- Column Q is the raw MrTau output, non-FP non-actinide isotopes and elements are not in MrTau. So, these are always zero. They are added back into the output flow in column R and S.

- Column $\mathrm{U}$ is the reactor delta (output-input) based on the adjusted output (column $\mathrm{S}$ ) and the input (column T).

- Cell U301 is the consumption of actinides from the MrTau calculation. For the recipes provided with FIT, these will match the corresponding consumption of actinides in cell X301 for the corresponding original impurity-free recipe for the first recycle iteration. This denotes that the neutron flux in the MrTau calculation is such that an equivalent power is produced. If the user installs new original recipes in MrTauWinery, the neutron flux in the Transmutation Parameter worksheet of MrTauWinery must be adjusted so that cells U301 and X301 (both shaded green) match for the first iteration. The cells will typically diverge for later iterations.

- Columns V, W, and X contain the input, output, and delta of the original impurity-free recipe in MrTauWinery. (It is copied and pasted from there.)

- Column $\mathrm{Z}$ contains the trustworthy test. If the cell is "yes", then column AA uses the adjusted output value from column $\mathrm{S}$. If the cell is "no", then column AA uses the sum of what was sent to the reactor plus what the original impurity-adjusted recipe indicates would be created in the reactor, i.e., the output calculation from MrTau is discarded for that isotope.

- "Yes" is hardwired for the actinides, for which there is more experience with MrTau.

- "No" is hardwired for isotopes not in MrTau.

- "No" is also hardwired for isotopes we know are not reliable in the current version of MrTau, especially the mass-135 isomer and Ag110/Ag110m. 
- All other isotopes are tested. If the FIT/MrTau calculated fission product mass gain is small (M 1 $\mathrm{kg} / \mathrm{yr}$ ), it is trusted. If not, the second test is whether the FIT/MrTau result is less than the AB4 cell $($ default $=5)$ times the gain in the original impurity-free composition. If so, it is trusted.

- Values for the test (cell AB4) of 5-7 have been shown to produce appropriate mass balance, i.e., the adjusted output mass flow is approximately what was sent to the reactor, i.e., cells AA303 and T303 are adequately close.

- In this sense, FIT 1.0 is equivalent to setting all of Column $\mathrm{Z}$ for fission products to "no" as that version of MrTau did not calculate fission products.

- The user, of course, is free to change the value in the cell AB4 or devise a different trustworthy test.

- The issues with MrTau stem numerical problems in its depletion calculations. This is being worked independently from FIT. We hope and anticipate a new version of MrTau to be available soon. If so, it can be installed in the FIT V2.0 directory (with the same name as the old file). If indeed it is superior, the trustworthy test will return "yes" for more or all fission products.

Reactor_Storage calculates the input spent fuel inventory change (due to decay and in-growth) for the specified number of years of storage after irradiation in the reactor. Cell K2 has the numbers of years of storage between reactor output and input to separation2, this value is input on the Control worksheet, not here! The length of storage is used to calculate the aged composition, which is then used in separation2.

\subsubsection{Separation 2}

There no user inputs on these worksheets. The user must select the process option for Separation 2 on the control worksheet.

Separation information should be input on worksheets UREX_1a calculations and separation matrices.

Calc_Sep2 calculates the inventory going to each of the output separation streams based on the split factors in the worksheet Sep_Matrices and based on the user input of the selected separation process. The columns on the left bring in the reactor output stream. The user-selected options on the Control worksheet and the values on worksheets UREX_1a calculations and separation matrices are copied to the block on this page called "separation 2". The separation matrix then produces the mass streams further to the right. Cell J34 should read "Mass is balanced". If not, there is an error with the separation matrix.

Sep2_Storage calculates the input spent fuel inventory change (due to decay and in-growth) for the specified number of years of storage between separations and fuel fabrication. There are three blocks of data, but "U-TRU product 2" is not currently being used. "From Sep 2" brings into the page the output from separation-2. Cell M2 has the numbers of years of storage between separation-2 and fuel blend/reactor input, this value is input on the Control worksheet, not here! The length of storage is used to calculate the aged composition, which is then used in the blending and fuel fabrication calculations.

\subsubsection{Waste Streams}

The FIT model includes the necessary blocks for tracking waste streams separated from used fuel during recycling and produced during recycle fuel fabrication. Operating and maintenance wastes for separations and fuel fabrication are also included; but operating and maintenance wastes from front-end processes, the first (LWR) reactor, and the recycle reactor are not included in the model at this time. If 
these presently-excluded waste streams are determined through future analyses to be potentially significant in analyzing different fuel cycle options, then they may be included in future versions of FIT.

The model is designed to enable user-selected waste treatment options that are defined to meet userintended waste dispositions that could dictate what treatments, waste forms, and waste loadings are needed. The model adopts waste forms that are generally consistent with recent studies of the Integrated Waste Management Strategy [Gombert 2008], the Advanced Fuel Cycle Facility (AFCF) design [DOE 2007], and the Waste Form Campaign [Vienna 2010].

Potential waste streams and waste forms are summarized in Table 3-2. The different separations processes do not produce all of these waste streams; zero values are present in the model for waste streams that are not produced in that specific separations process. Masses and volumes of the waste forms are calculated based on waste loadings of the waste forms, consistent with models developed for glass (Ryan 2009) estimations made by the Integrated Waste Management Strategy, the AFCF, and the Waste Form Campaign. Waste packaging, and the impacts on waste volumes and masses introduced by waste packaging, are not yet included in the model.

Table 3-2. Waste streams and waste forms in the FIT model.

\begin{tabular}{|c|c|c|c|}
\hline $\begin{array}{c}\text { Separated waste } \\
\text { isotope(s) }\end{array}$ & $\begin{array}{c}\text { From these } \\
\text { separations processes }\end{array}$ & Waste form & Comments \\
\hline $\mathrm{C}-14$ & $\begin{array}{l}\text { All except } \\
\text { electrochemical }\end{array}$ & Grouted carbonate & $\begin{array}{l}\text { Based on longevity and potential } \\
\text { mobility; free release to the } \\
\text { atmosphere may be allowed (Waste } \\
\text { Form Campaign current reference } \\
\text { case). In that case, there would be no } \\
\text { C-14 waste form. }\end{array}$ \\
\hline $\begin{array}{l}\text { I-129 (and co- } \\
\text { collected halogens) }\end{array}$ & All & Ag zeolite & $\begin{array}{l}\text { Based on longevity and potential } \\
\text { mobility }\end{array}$ \\
\hline Tc-99, UDS & UREX+1 & Metal ingot & $\begin{array}{l}\text { Based on longevity and potential } \\
\text { mobility. Could be combined with } \\
\text { HLW glass. }\end{array}$ \\
\hline Tritium & All & $\begin{array}{l}\text { Grouted Tritiated } \\
\text { water }\end{array}$ & $\begin{array}{l}\text { Generally accepted disposition, } \\
\text { although disposition as HLW may } \\
\text { still be required; or free release may } \\
\text { be allowed after sufficient decay } \\
\text { prior to separations }\end{array}$ \\
\hline $\begin{array}{l}\mathrm{Kr}-85 \text { (and other } \mathrm{Kr} \\
\text { and Xe isotopes) }\end{array}$ & All & Compressed gas & $\begin{array}{l}\text { Free release after sufficient decay } \\
\text { time }\end{array}$ \\
\hline $\begin{array}{l}\text { Cladding, UDS, } \\
\text { baskets }\end{array}$ & Electrochemical & Metal ingot & $\begin{array}{l}\text { Tc-99, other transition metals (except } \\
\text { for some } \mathrm{Zr} \text { ), and other semi-metals } \\
\text { including Te stay undissolved and } \\
\text { partition in UDS with the cladding }\end{array}$ \\
\hline Raffinate/residual & All but electrochemical & Glass & $\begin{array}{l}\text { Could include Tc, UDS, Cs/Sr, and } \\
\text { lanthanides in aqueous separations }\end{array}$ \\
\hline $\begin{array}{l}\text { Raffinate/residual } \\
\text { (salt waste) }\end{array}$ & Electrochemical & $\begin{array}{l}\text { Glass-bonded } \\
\text { zeolite }\end{array}$ & \\
\hline $\mathrm{Cs} / \mathrm{Sr}$ & UREX+1 & $\begin{array}{l}\text { Mineralized } \\
\text { monolith }\end{array}$ & $\begin{array}{l}\text { Could (or may be required to) be } \\
\text { combined with HLW glass, } \\
\text { depending on waste policy } \\
\text { interpretation or economics }\end{array}$ \\
\hline
\end{tabular}




\begin{tabular}{|l|l|l|l|}
\hline Lanthanides & UREX +1 & Glass & Could be combined with HLW glass \\
\hline Cladding/coatings & Aqueous & Compacted & $\begin{array}{l}\text { Presumes residual TRU } \\
\text { contamination }>10 \mathrm{nCi} / \mathrm{g}\end{array}$ \\
\hline Structure/hardware & All & Compacted & $\begin{array}{l}\text { Presumes combined with } \\
\text { Cladding/coatings }\end{array}$ \\
\hline Spent solvents-liquids & UREX+1 & $\begin{array}{l}\text { Mineralized } \\
\text { monolith }\end{array}$ & $\begin{array}{l}\text { Presumes TRU can be reduced to }<10 \\
\text { nCi/g }\end{array}$ \\
\hline $\begin{array}{l}\text { Fuel fabrication } \\
\text { wastes }\end{array}$ & --- & Compact & \\
\hline $\begin{array}{l}\text { Operations and } \\
\text { maintenance wastes }\end{array}$ & All & $\begin{array}{l}\text { Mineralized } \\
\text { monolith }\end{array}$ & $\begin{array}{l}\text { Presumes some wastes contaminated } \\
\text { with TRU }>10 \text { nCi/g }\end{array}$ \\
\hline $\begin{array}{l}\text { Operations and } \\
\text { maintenance wastes }\end{array}$ & All & $\begin{array}{l}\text { Mineralized } \\
\text { monolith }\end{array}$ & $\begin{array}{l}\text { Presumes some wastes with TRU } \\
<10 \mathrm{nCi} / \mathrm{g}\end{array}$ \\
\hline
\end{tabular}

\subsubsection{Carbon-14}

The model includes the following assumptions and estimates as input or bounding conditions.

- Carbon, in fuel meat of either oxide or metal fuels, present as either an impurity or fission product, will partition differently for some different separations processes. The carbon within fuels is relatively small and should stay bound in the fuel structure. The assumption of oxidation is unlikely for metal fuel fabricated in an argon atmosphere. Loss of process additions of hydrocarbons occurs in oxide fuel sintering but there has never been any attempt to capture the $\mathrm{CO}_{2}$ as a waste. (FIT is set up to track both $\mathrm{C}-14$ and $\mathrm{C}$-other. There is nil C-other as a fission product, so data are needed regarding the amount of other carbon from processing fluids.) Any amount of this carbon that evolves to process gas streams, regardless of the separations process, is presumed to eventually oxidize to gaseous $\mathrm{CO}_{2}$ that requires capture and retention in a solid waste form for disposal. In reality, regulatory emission regulations for $\mathrm{C}-14$ may enable regulatory-compliant atmospheric discharge of any gasified C-14.[Soelberg 2009, Vienna 2010] The model accounts for the more conservative possibility that $90 \%$ of the gasified carbon is quantitatively captured (after oxidation to $\mathrm{CO}_{2}$ ) using a caustic scrubber, and stabilized in a solid calcium carbonate grout. (Carbonates of magnesium and sodium are also possibilities that are not included in this model.) The value of capture efficiency can be varied by the user.

- High levels of contamination by stable carbon in $\mathrm{CO}_{2}$ contributed from air or by other process materials could dilute the amount of radioactive $\mathrm{CO}_{2}$ from the used fuel, and proportionately increase the amount of the $\mathrm{CaCO}_{3}$ waste form. The AFCF study assumed a 100x dilution factor (and corresponding 100x increase in the $\mathrm{CaCO}_{3}$ waste form) from $\mathrm{CO}_{2}$ in process air.[DOE 2007]

- C-14 is assumed to partition quantitatively to the recovered U stream and the undissolved cladding and metal stream in electrochemical separations. In this case, no separate grouted C-14 waste stream is assumed; no dilution from tramp $\mathrm{CO}_{2}$ from air is assumed, since the electrochemical separations process is performed in an inert Ar atmosphere; and the C-14 is just one of many isotopes that are impurities in the recovered $U$ and fission products in the electrochemical metal waste form. The electrochemical metal waste form contains most of the Tc and lesser amounts of other fission products that do not dissolve in the electro refiner molten salt bath.

- Carbon, as a trace constituent in metal cladding and structural materials, remains with those metals if those metals are not dissolved during a separations process. Carbon in metals that are dissolved would partition to the process stream that contains those metals. 
- Carbon in carbon-based or SiC-based cladding, fuel element, and core structure, is either oxidized to gaseous $\mathrm{CO}_{2}$ if those materials are oxidized; or if those materials are not combusted, then the carbon partitions to the process stream that contains those carbon-based materials. These materials are not present in the current version of the model because it is not yet tailored for use cases that include graphite or SiC-based cladding, fuel elements, or core structures that would exist in HTGR or MSR reactors.

\subsubsection{I-129 and other halogens}

The model includes the following assumptions and estimates as input or bounding conditions.

- I-129 and other halogens in the used fuel are assumed to partition almost quantitatively to process gas streams in all but electrochemical separations, during which it partitions almost quantitatively to the glass-bonded ceramic fission product waste stream.

- Nearly quantitative capture of I-129 is assumed to be necessary to meet air emission limits. Even the trace amount of I-129 (0.1 wt $\%$ of the total I-129) that is assumed to partition to process gas streams during electrochemical separations is assumed to be captured to meet air emission limits. The I-129 and other halogens are quantitatively captured in the model using silver-impregnated zeolite sorbent, which is the final waste form (the Separations and Waste Form Campaigns are also studying alternative sorbents and waste forms). The Ag-zeolite waste form is assumed to have a waste loading of $2.53 \mathrm{wt} \%$ for total halogens.

- At this time, contamination of halides such as from trace contamination in nitric acid used in aqueous separations processes is not accounted for. Accounting for contaminants such as these could increase the amount of the I-129 final waste form if they evolve in gas streams with the I129 , and are captured (as would be expected) in the Ag zeolite along with the I-129.

\subsubsection{Tc-99}

Technetium behaves differently in the different separations processes in this model. The model includes the following assumptions and estimates as input or bounding conditions.

- UREX+1 separates most of the Tc into a separate waste stream that is combined with Zircalloy (from cladding) and stainless steel (from fuel assembly structural steel) into a melted metal waste form that contains not more than $5 \mathrm{wt} \% \mathrm{Tc}$.

- The Tc is assumed to not dissolve in electrochemical separations and so remains with cladding, other metals, and other fission products, inert materials, or contaminants that do not dissolve into the molten salt bath of the electro refiner.

- These electro refiner UDS are purified a separate melter that removes and recycles remaining fission product salts, and melts the UDS into a metal ingot. This mass is combined with the mass of the Tc metal waste form from UREX +1 separation for storage and disposal.

- Tc is assumed to nearly quantitatively partition to the fission product waste stream in AIROX separations.

- Tc is assumed to mainly remain with the U-TRU product during melt refining, although $8 \%$ of the total Tc is assumed to partition to the fission product waste stream. 


\subsubsection{UDS from UREX+1 separations}

Fuel meat materials that do not dissolve in the dissolver are may be either combined with the Tc into a metal waste form or combined with other FPs in a glass waste form. The user can determine this. Both the metal and glass waste forms have loading limits for the amount of this UDS, so this UDS can affect the final mass of those waste forms.

\subsubsection{Tritium $(\mathrm{H}-3)$}

Tritium is assumed to evolve quantitatively to process gas streams in all separations processes. The amount that can be discharged to the atmosphere, within regulatory limits, varies depending on air dispersion and process facility size. The model assumes that $99 \%$ of the tritium requires capture, and $1 \%$ can be released. In all separations cases, the tritium is assumed to be converted to tritiated water, which is captured using standard industrial molecular sieve technology. The molecular sieve is thermally regenerated, and the captured tritiated water removed from the mole sieve is condensed and grouted into a solid waste form. The waste loading of tritium is $0.106 \mathrm{wt} \%$, because of dilution of the tritiated water with tramp water in the different processes or with water added to raise the moisture content of the process gas to a level at which $99 \%$ of the total water can be captured in the mole sieve.

\subsubsection{Noble gases}

Noble gases including Kr-85, the only significant radioactive noble gas fission product (at waste management time scales), will almost quantitatively evolve to the process gas streams in all separations processes. These gases are captured onto a zeolite sorbent, and desorbed and compressed into gas cylinders for storage and disposal.

Alternatives that could be included by the user or in future FIT model revisions include the separation of $\mathrm{Kr}$ from other (stable) noble gases (mainly Xe), which would reduce the amount of this waste form by about a factor of 10. The current version of FIT does not account for contamination that could occur in separations processes that might allow air inleakage or process air to introduce tramp Ar and $\mathrm{Ne}$, which would contaminate the $\mathrm{Kr} / \mathrm{Xe}$ waste stream if these tramp elements are not separated.

\subsubsection{Cladding and baskets from electrochemical separations}

The cladding and baskets that are used to hold the fuel in the electro refiner do not dissolve. The electro refiner UDS are purified a separate melter that removes and recycles remaining fission product salts, and melts the UDS into a metal ingot. This mass is combined with the mass of the Tc metal waste form from UREX+1 separation for storage and disposal.

\subsubsection{8 "Raffinate/residual" fission product wastes}

For simplicity, the waste stream from any of the separations processes that contains the majority of the fission products is called, after the UREX +1 nomenclature, as "raffinate/residual" wastes. These waste streams from all but electrochemical separations are vitrified into a glass waste form based on the glass waste form model used in FIT.

The fission product-bearing electro refiner salt from electrochemical separations is stabilized in a glassbonded zeolite waste form. The maximum assumed FP waste loading is assumed to be $5 \mathrm{wt} \%$. 


\subsubsection{Lanthanides from UREX+1 separations}

UREX +1 can separate the lanthanides from other product and waste streams. These lanthanides can be converted in the model into either a lanthanide glass or total combined fission product glass waste form, with or without UDS that did not dissolve in the dissolver, using the glass model in FIT.

\subsubsection{Cladding and coatings from all but electrochemical separations}

The cladding, and coating for fuel are assumed to be separated from the used fuel in all separations processes. In all but electrochemical separations, metal cladding can be combined with Tc and other metal and converted to a metal Tc waste form. Cladding metal and any non-metallic cladding/coatings that are not otherwise used or oxidized to process gases are decontaminated (to a limited degree) and compacted into a final waste form.

\subsubsection{Fuel assembly structure and hardware}

Fuel assembly structure and hardware is expected to have activation products and possibly have some contamination of fission products, and will require handling as radioactive waste or products. This metal is cut away from fuel assemblies before the fuel rods are chopped, to minimize contamination. The metal can be added to cladding and Tc to make a Tc metal waste form. Any metal left over can be compacted and discarded as radioactive waste.

\subsubsection{Cs/Sr from UREX+1 separations}

$\mathrm{UREX}+1$ can separate the $\mathrm{Cs} / \mathrm{Sr}$ (and other Group 1A/2A isotopes) from the other waste and product streams. While the $\mathrm{Cs} / \mathrm{Sr}$ waste stream can be combined with fission products and converted to a glass waste form (as is done in the other separations processes) this waste stream can also be converted to an aluminosilicate waste form for separate handling, storage, and disposal. The maximum expected waste loading is about $31 \mathrm{wt} \%$, but this value does not consider limitations due to decay heat generation.

\subsubsection{Spent solvents and liquids from UREX+1 separations}

The complex UREX+1 separations process includes multiple steps and multiple solvents and extractions. The organic solvents degrade over time due to radiation damage to the organic molecules. Fresh solvents are added to enable spent solvents to be discharged. These liquid streams are thermally treated in the model to reduce both the mass and volume of the final waste form, and to convert the waste into an aluminosilicate waste form suitable for disposal. Through thermal treatment, the waste mass is reduced by about $100 x$.

\subsubsection{Fuel fabrication waste streams}

Several waste streams are created from fuel fabrication. The streams included in this model for mixed oxide fuel fabrication are shown in Table 3-3. The solid waste streams (Iso Blend waste, container wastes, HEPA wastes, scrap, other solids) are presumed to contain the same isotopic proportions as are in the final fuel, for simplicity. These waste streams are compacted and packaged for final disposition. 
Table 3-3. Mixed oxide fuel fabrication waste streams from worksheet "Summary_O".

\begin{tabular}{|c|c|}
\hline \multicolumn{2}{|l|}{ FUEL WASTES } \\
\hline Fuel From Iso Blend (g) & 926 \\
\hline \multicolumn{2}{|l|}{ Fuel From Process } \\
\hline Container Waste $(\mathrm{g})$ & 9,075 \\
\hline HEPA Filter Waste $(\mathrm{g})$ & 8445 \\
\hline \multicolumn{2}{|l|}{ Fuel From Recovery } \\
\hline Container Waste $(\mathrm{g})$ & 1,139 \\
\hline HEPA Filter Waste $(\mathrm{g})$ & 83 \\
\hline Fuel From QC Testing (g) & 1,042 \\
\hline \multicolumn{2}{|l|}{ PROCESS BY-PRODUCTS } \\
\hline \multicolumn{2}{|l|}{ Fuel Iso Blend HEPA Exhaust } \\
\hline Hydrogen & 20,374 \\
\hline $\mathrm{NO} 3$ & $1,253,366$ \\
\hline Water & $1,274,538$ \\
\hline \multicolumn{2}{|l|}{ Fuel Process Wastes } \\
\hline $\begin{array}{ll}\text { HEPA Filter Solids }(\mathrm{g}) \\
\end{array}$ & $\mathbf{0}$ \\
\hline Gaseous Discharge (g) & 1 \\
\hline \multicolumn{2}{|l|}{ Recovery Process Wastes } \\
\hline Scrap Fuel Cladding and Fines (g) & 319 \\
\hline Chemical Solids (SiC, Tramp Matl.) (g) & $\mathbf{5 , 2 7 0}$ \\
\hline Waste Water (g) & 46,592 \\
\hline \multicolumn{2}{|l|}{ QC Testing Wastes (g) } \\
\hline Gaseous Discharge through HEPA's & 10,502 \\
\hline Process Water \& Acids & 0 \\
\hline Mercury & 54 \\
\hline Metallograpy Compounds & 967 \\
\hline
\end{tabular}

\begin{tabular}{|c|c|}
\hline \multicolumn{2}{|l|}{ FUEL WASTES } \\
\hline Fuel From Iso Blend (g) & 926 \\
\hline \multicolumn{2}{|l|}{ Fuel From Process } \\
\hline Container Waste $(\mathrm{g})$ & 9,075 \\
\hline HEPA Filter Waste (g) & 8445 \\
\hline \multicolumn{2}{|l|}{ Fuel From Recovery } \\
\hline Container Waste $(\mathrm{g})$ & 1,139 \\
\hline HEPA Filter Waste (g) & 83 \\
\hline Fuel From QC Testing (g) & 1,042 \\
\hline \multicolumn{2}{|l|}{ PROCESS BY-PRODUCTS } \\
\hline \multicolumn{2}{|l|}{ Fuel Iso Blend HEPA Exhaust } \\
\hline Hydrogen & 20,374 \\
\hline NO3 & $1,253,366$ \\
\hline Water & $1,274,538$ \\
\hline \multicolumn{2}{|l|}{ Fuel Process Wastes } \\
\hline $\begin{array}{ll}\text { HEPA Filter Solids (g) }\end{array}$ & $\mathbf{0}$ \\
\hline Gaseous Discharge $(\mathrm{g})$ & 1 \\
\hline \multicolumn{2}{|l|}{ Recovery Process Wastes } \\
\hline Scrap Fuel Cladding and Fines (g) & 319 \\
\hline Chemical Solids (SiC, Tramp Matl.) (g) & 5,270 \\
\hline Waste Water (g) & 46,592 \\
\hline \multicolumn{2}{|l|}{ QC Testing Wastes (g) } \\
\hline Gaseous Discharge through HEPA's & 10,502 \\
\hline Process Water \& Acids & $\mathbf{0}$ \\
\hline Mercury & 54 \\
\hline Metallograpy Compounds & 967 \\
\hline
\end{tabular}

\subsubsection{Separations process operations and maintenance wastes}

Separations process operations and maintenance wastes will include contaminated personal protective equipment (PPE) for radiation workers, decontamination solutions, filters, and spent and discarded tools and equipment, including process equipment and hot cell maintenance wastes. Metallic wastes are decontaminated to the extent practical, compacted, and packaged for disposal. Inorganic filters and frames are leached to decontaminate and recover TRU and fission products, and compacted. 
Liquid and organic wastes can be significantly volume-reduced by thermal treatment, incineration, evaporation, etc. These are volume-reduced by about a factor of $100 x$, and mass-reduced by a factor of 10x, and stabilized in an aluminosilicate waste form.

Considering the volume and mass reduction of the organic and liquid wastes, the potential contamination on spent/discarded tools and equipment suggests that a portion of these wastes may be contaminated with TRU elements at levels that make them candidates for subsurface geologic disposal.

\subsection{In MrTauWinery Excel2007 File}

MrTauWinery is a standalone physics tool. Therefore, most of the spreadsheet should not be changed by a FIT user. Indeed, many parts of the tool are not used by FIT. The parts of the MrTauWinery Excel2007 file of interest to the FIT user are described in the following sections.

Indeed, the input adjustment parts of MrTauWinery Excel2007 file have 20 cases, primarily intended for stand-alone use of this file. Four of the cases have been utilized for FIT purposes. None of the formats can be changed. But, the data in these cases can be changed for FIT purposes. These cases and their current contents are as follows:

$$
\begin{aligned}
& 14=\text { Fast reactor, metal fuel, } \mathrm{CR}=0.5 \text {, startup composition } \\
& 15=\text { Fast reactor, oxide fuel, } \mathrm{CR}=0.5 \text {, startup composition } \\
& 16=\text { Fast reactor, metal fuel, } \mathrm{CR}=0.5 \text {, equilibrium composition } \\
& 17=\text { Fast reactor, oxide fuel, } \mathrm{CR}=0.5 \text {, equilibrium composition }
\end{aligned}
$$

If a user wants to install different recipes, they need to adjust the data for cases $14-15-16-17$ on these worksheets:

\section{- Transmutation parameters}

- Initial recipes

- Cross sections

\subsubsection{Calc input adjust (FP)}

The user should not change anything on this worksheet.

When this file is used as a standalone tool, the parallel worksheet, Calc input adj, is used. For FIT purposes, this worksheet, Calc input adjust (FP), is used. Unlike the former, it allows for composition adjustment of impurities and isotopes, as well as three types of uranium, RU-1, RU-2, or DU.

Cell Q1 is provided by FIT; it selects among the three uranium cases.

Cells L282, M282, and N282 are the percentages of RU-1, RU-2, and DU used to make the uranium composition used in making the final TRU-U blend. At present, the only values that will appear in these cells are $0 \%$ and $100 \%$, with $100 \%$ being which type of uranium the user selected in FIT. That is, the model does not allow for the possibility that the supply of RU-1 or RU-2 would be insufficient or for a deliberate blending of RU-1 and RU-2. The user can replace the values in these cells and break the link to the cell Q1, however, they must still total to $100 \%$.

Cells Q285 and S285 are the calculated required blending of the TRU-U and U products respectively. Since both products can have uranium, TRU, and impurities, these blending percentages are not the same 
as the TRU:U in the finished product. Those numbers are in column V. Cell V10 is the fraction of uranium, cell V34 is the fraction of TRU, and cell V280 is the fraction of impurities.

\subsubsection{Transmutation Parameters}

This worksheet contains key transmutation parameters. Cases 14-15-16-17 are the options that FIT can use. If new recipes are added, then the values in those columns on this page must be changed accordingly.

Row 5 should be 1 for thermal, 2 for fast reactors. This controls which set of branching ratios and fission yield curves that MrTau uses. It does not control cross sections, as those are user input in another worksheet below.

Row 6 the problem time in calendar years

Row 7 is calculated

Row 8 is the number of time steps for MrTau to use. 1000 works for the existing cases.

Row 10 is the number of time steps per output, e.g., a value of 100 here and 1000 in row 8 means there will be 10 lines of output. FIT doesn't care as it only uses the last value. This data-thinning feature only works for MrTau standalone calculations where MrTau -Fortran is being asked to perform multi-recycle calculations. Simplistic multi-recycle transmutation and partitioning simulation is a feature of MrTauFortran however the code is used for only a single reactor-pass in FIT. The blending and mass tracking features of FIT are more advanced than the multi-recycle feature of MrTau-Fortran standalone. For single-reactor passes, the output data thinning routine in MrTau-Fortran is disabled.

Row 11 is the neutron flux. For new recipes, this must be iterated so that the power level and actinide consumption are correct, see description of the FIT/Reactor_Output worksheet. For fast reactor cases stemming from Ed Hoffman's fast reactor parameter scans, note that he kept the neutron fluence constant at $4 \mathrm{e} 23$ neutrons/cm2-sec. So, a first approximation of the flux can be calculated by $4 \mathrm{e} 23$ divided by the irradiation time in row 7 (converted to seconds). Testing of cases 14-15-16-17 indicated a modest adjustment was needed (row 17) to exactly match the desired actinide consumption. The adjustment is necessary to account for the fact that MRTAU is a zero dimensional transmutation calculation, whereas Hoffman's recipe's were generated via detailed three-dimensional reactor core simulation.

Row 13 is the neutron fluence, in GWth-day/tonne-iHM.

\subsubsection{Initial recipes}

The user can change cases 14 through 17 to run FIT with different compositions corresponding to other than $\mathrm{CR}=0.5$ fast reactors. However, the formats must not change.

The user can change cases 14 through 17 to run FIT with different compositions corresponding to other Note that there are three blocks of rows. The user must have self-consistent data in all three blocks.

- The block of rows called Input mass fractions has the fractions of input fuel composition (must total to 1.0 or mass is lost or created)

- The block of rows for Output mass fractions has the fractions of output fuel composition (must total to 1.0$)$. 


\subsubsection{Available material}

The user should not change anything on this worksheet.

FIT places the available TRU-U product isotopic data into column B.

\subsubsection{Available uranium}

There are three columns for RU-1, RU-2, and DU. These are used by "calc input adjust (FP)". When MrTauWinery is used as a standalone tool, the user may change any of these columns of data. However, when MrTauWinery is used with FIT, the user can only change the DU column. If the user changes RU-1 or RU-2, they will be written over by copy and paste operations by FIT, in which the appropriate RU-1 and RU-2 compositions calculated by FIT are inserted here.

\subsubsection{Cross sections}

In the stand-alone tool, the user would select the data to have in column B. With FIT, the user selects among cases 14-15-16-17 and FIT copies that column's data into column B.

Column B is used by worksheet calc input $\operatorname{adj}(\mathbf{F P})$ and is copied by FIT into the budep.inp worksheet for use by the Fortran executable.

Therefore, if cases 14-15-16-17 are altered by the user, the appropriate cross sections must be entered into those columns. 


\section{4. $\quad$ OUTPUTS}

Most of the output data a user would want is found on the Flow, Output, and Output2 worksheets in FIT. Few of the other worksheets have output information that the user would tend to want. A few possible exceptions are noted below.

The output data are simply numbers; the user must graph or compare them to impurity limits as he or she sees fit. For example, there is a Excel2007 file that compares the cases run in September 2010 to the current Fuels Campaign working limits and graphs them, see section 4.2.

\subsection{Flow Worksheet}

Figure 4-1 shows the graphic produced on the Flow worksheet. It is an overall mass flow of the simulation at the last recycle iteration of the calculation. 


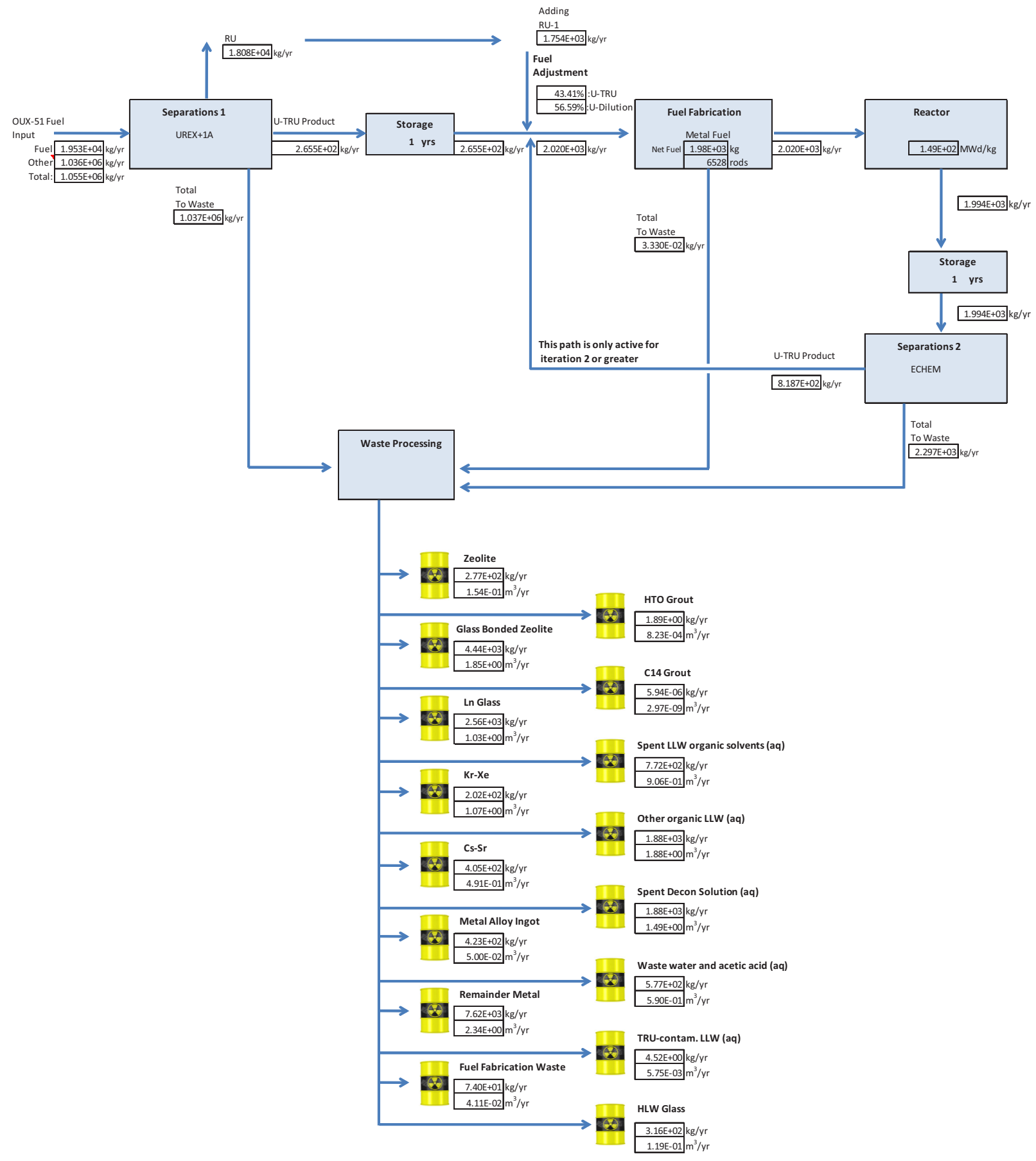

Figure 4-1. Mass flow diagram.

\subsection{Output Worksheet}

Table 4-1 lists the information provided in the output worksheet. For example, if one wants to consider the composition of fresh fuel in the recycling reactor, use mass flows, to recycling reactor, columns LI to OL. 
Table 4-1. Information available on the Output Worksheet.

\begin{tabular}{|c|c|c|}
\hline Category & What parameters & Which Columns \\
\hline $\begin{array}{l}\text { Simulation } \\
\text { settings }\end{array}$ & $\begin{array}{l}\text { Listing of settings that the user } \\
\text { selected on the Control } \\
\text { worksheet }\end{array}$ & A \\
\hline Reactor power & $\begin{array}{l}\text { The power of the recycling } \\
\text { reactor supported each iteration } \\
\text { (The incoming fuel via } \\
\text { separation } 1 \text { is normalized to } 1 \\
\text { GWe) }\end{array}$ & GR \\
\hline Reactor burnup & $\begin{array}{l}\text { Fractional consumption of } \\
\text { actinides }\end{array}$ & GP \\
\hline $\begin{array}{l}\text { Blending } \\
\text { fractions }\end{array}$ & $\begin{array}{l}\% \text { TRU } \\
\% \text { U } \\
\text { Caution: these are the blending } \\
\text { fractions of TRU-U product } \\
\text { (combined from TRU-U-1 and } \\
T R U-U-2 \text { ) and uranium product } \\
\text { (from } R U-1, R U-2, \text { or DU). } \\
\text { These are not the TRU: } U \\
\text { compositions in the fuel, which } \\
\text { must instead be obtained by } \\
\text { mass fractions or mass flows, see } \\
\text { below. }\end{array}$ & $\begin{array}{l}\text { GM } \\
\text { GN }\end{array}$ \\
\hline $\begin{array}{l}\text { Out of reactor } \\
\text { actinide } \\
\text { fractions }\end{array}$ & $\begin{array}{l}\% \text { actinides } \\
\% \text { other }\end{array}$ & $\begin{array}{l}\text { GT } \\
\text { GU }\end{array}$ \\
\hline $\begin{array}{l}\text { Waste } \\
\text { management } \\
\text { (totals for each } \\
\text { parameter for } \\
\text { each tracked } \\
\text { isotope, element, } \\
\text { and group of } \\
\text { chemical } \\
\text { elements.) }\end{array}$ & $\begin{array}{l}\text { Heat }(\mathrm{W} / \mathrm{yr}), \\
\text { Gamma }(\mathrm{W} / \mathrm{yr}), \\
\text { neutron }(\mathrm{W} / \mathrm{yr}), \\
\text { neutron number (\#/s per year), } \\
\text { radiotoxicity }(\mathrm{Sv} / \mathrm{yr}) \text { at } \mathrm{t}=0, \\
\text { radiotoxicity }(\mathrm{Sv} / \mathrm{yr}) \text { at } \mathrm{t}=10,000 \\
\text { years after reactor discharge, } \\
\text { Mass }(\mathrm{kg} / \mathrm{yr}) \\
\text { Volume }(\mathrm{m} 3 / \mathrm{yr})\end{array}$ & $\begin{array}{l}\text { HLW - C to J } \\
\text { LLW class A/B/C - L to S } \\
\text { Mixed LLW - U to AB } \\
\text { LLW from decayed storage - AD to AL } \\
\text { Mixed LLW from decayed storage - AN to AV } \\
\text { LLW-GTCC - AX to BE } \\
\text { Zeolite - BG to BO } \\
\text { Kr-Xe - BP to BX } \\
\text { Cs-Sr - BY to CG } \\
\text { Metal alloy ingot - CH to CP } \\
\text { Remainder metal - CQ to CY } \\
\text { HTO grout - CZ to DH } \\
\text { C-14 grout - DI to DQ } \\
\text { LLW mineralized monolith - DR to DZ } \\
\text { TRU mineralized monolith - EA to EI } \\
\text { Glass - EJ to ER } \\
\text { Glass-bonded zeolite - ES to FA } \\
\text { Fuel fabrication waste - FB to FJ } \\
\text { Operational waste - FK to FS } \\
\text { Operational waste (TRU) - FT to GB } \\
\text { Lanthanide glass - GC to GK }\end{array}$ \\
\hline $\begin{array}{l}\text { Waste } \\
\text { (totals) }\end{array}$ & $\begin{array}{l}\mathrm{Kg} / \text { year } \\
\mathrm{M} 3 / \text { year }\end{array}$ & $\begin{array}{l}\text { Zeolite - HA-HB } \\
\mathrm{Kr}-\mathrm{Xe}-\mathrm{HG}-\mathrm{HE}\end{array}$ \\
\hline
\end{tabular}




\begin{tabular}{|l|l|}
\hline & Cs-Sr - HJ-HK \\
& Metal alloy ingot - HM-HN \\
& Remainder metal - HP-HQ \\
& HTO grout - HS-HT \\
& C-14 grout - HV-HW \\
& Glass - IS-IT \\
& Glass-bonded zeolite - HD-HE \\
& Fuel fabrication waste - IJ-IK \\
& Operational waste - IM-IN \\
& Operational waste (TRU) - IP-IQ \\
\hline
\end{tabular}

\subsection{Output2 Worksheet}

Table 4-1 lists the information provided in the output worksheet. The FIT macro's copy and paste data into rows 4 to 290. Totals by chemical element are calculated in rows 301 to 399.

Table 4-2. Information available on the Output Worksheet.

\begin{tabular}{|l|l|l|}
\hline Category & What parameters & Which Columns \\
\hline Simulation settings & $\begin{array}{l}\text { Listing of settings that the user selected on the } \\
\text { Control worksheet }\end{array}$ & A \\
\hline Available material & $\begin{array}{l}\text { Mass fractions of the combined TRU+U product } \\
\text { from Sep1 (and Sep2 if user requested) }\end{array}$ & C to W \\
\hline Adjusted composition & $\begin{array}{l}\text { Mass fractions of the adjusted fuel blend } \\
\text { produced by the Adj Fuel Input(FP) worksheet) }\end{array}$ & X to AQ \\
\hline Inventory to Sep1 & Mass flow (kg/year) going into Sep1 & MZ to NS \\
\hline Sep1 to Fuel Fabrication & Mass flow (kg/year) going from Sep1 to fab & NT to OM \\
\hline Inventory to Sep2 & Mass flow (kg/year) going into Sep2 & AR to BK \\
\hline Sep2 to Fuel Fabrication & Mass flow $(\mathrm{kg} /$ year) going from Sep2 to fab & ON to PG \\
\hline Inventory to reactor & Mass flow (kg/year) going into the reactor & BL to CE \\
\hline Recovered Uranium 1 & Flow (kg/year) & LL to ME \\
\hline Recovered Uranium 2 & Flow (kg/year) & MF to MY \\
\hline Waste - Zeolite & Waste flow (kg/year) & CF to CY \\
\hline Waste - glass bonded zeolite & Waste flow (kg/year) & CZ to DS \\
\hline Waste - KrXe & Waste flow (kg/year) & DT to EM \\
\hline Waste - CsSr & Waste flow (kg/year) & EN to FG \\
\hline Waste - metal alloy ingot & Waste flow (kg/year) & FH to GA \\
\hline Waste - remainder metal & Waste flow (kg/year) & GB to GU \\
\hline Waste - HTO grout & Waste flow (kg/year) & GV to HO \\
\hline Waste - C-14 grout & Waste flow (kg/year) & HI to II \\
\hline Waste - Solvents Liquids & Waste flow (kg/year) & IJ to JC \\
\hline Waste - Fuel Fabrication & Waste flow (kg/year) & JD to JW \\
\hline Ops waste & Waste flow (kg/year) & JX to KQ \\
\hline HLW Glass & Waste flow (kg/year) & KR to LK \\
\hline & & \\
\hline
\end{tabular}

\subsection{Comparison with Impurity Limits}

There are two steps required to compare FIT 1.0 outputs with Fuels Campaign Limits. 
1. Fuels limits on TRU feedstock must be translated into limits on the final fuel product. This was done in FY2009 for metal and oxide fast reactor fuels.[Shropshire2009]

2. Compare with the elemental composition on Output2.

\subsection{Other Information in FIT}

Of course, all data at every step of the calculation in FIT can be found within the FIT or MrTauWinery Excel2007 files. However, except for the data copied and pasted into the Output and Output2 worksheets, only the data for the most recent recycle iteration will be elsewhere in the FIT or MrTauWinery Excel2007 files. If these data are useful for a user, we can add them to the macro that copies and pastes data into the Output and Output 2 worksheets.

\subsubsection{Input data}

Column A of the Output worksheet displays the settings that were selected on the Control Worksheet.

\subsubsection{Fuel fabrication}

For oxide fuel, worksheet Summary_o provides for oxide fuel fabrication such as scrap streams, fuel recovery, overall process efficiency.

For metal fuel, worksheet Summary provides summary information for metal fuel fabrication such as scrap stream masses, fuel alloy returned to melter, etc.

\subsubsection{Waste management}

This model separately tracks the mass, volume, and isotopic content of each waste stream. This version of the model also presumes classification of waste streams into Class A/B/C, GTCC, mixed low-level, and HLW streams, based on current regulations and policies (NRC 2001, NRC 2009, NWPA 1982) and is generally consistent with the primary waste management reference sources [the Integrated Waste Management Strategy (IWMS, Gombert 2008), the Advanced Fuel Cycle Facility (AFCF) design (DOE 2007), and the Waste Form Campaign (Vienna 2010)].

Future versions of FIT could track partitioning of TRU and FPs to spent solvent and operations/maintenance waste streams, to compare these parameters to Class A, B, and C LLW limits, and to estimate how much of the TRU and FPs will be lost in all of the different waste streams. This will be important in enabling assessment of how to disposition waste streams based on their risk rather than based on their source.

\subsubsection{Waste Stream Outputs in FIT}

Each of the waste streams whose inputs are listed in Section 3 of this report is tracked on worksheets in the Excel file. Figure 4-2 shows the tables for the grouted tritium and C-14 waste forms. In these cases, no other isotopes are presumed to contaminate these waste forms. 

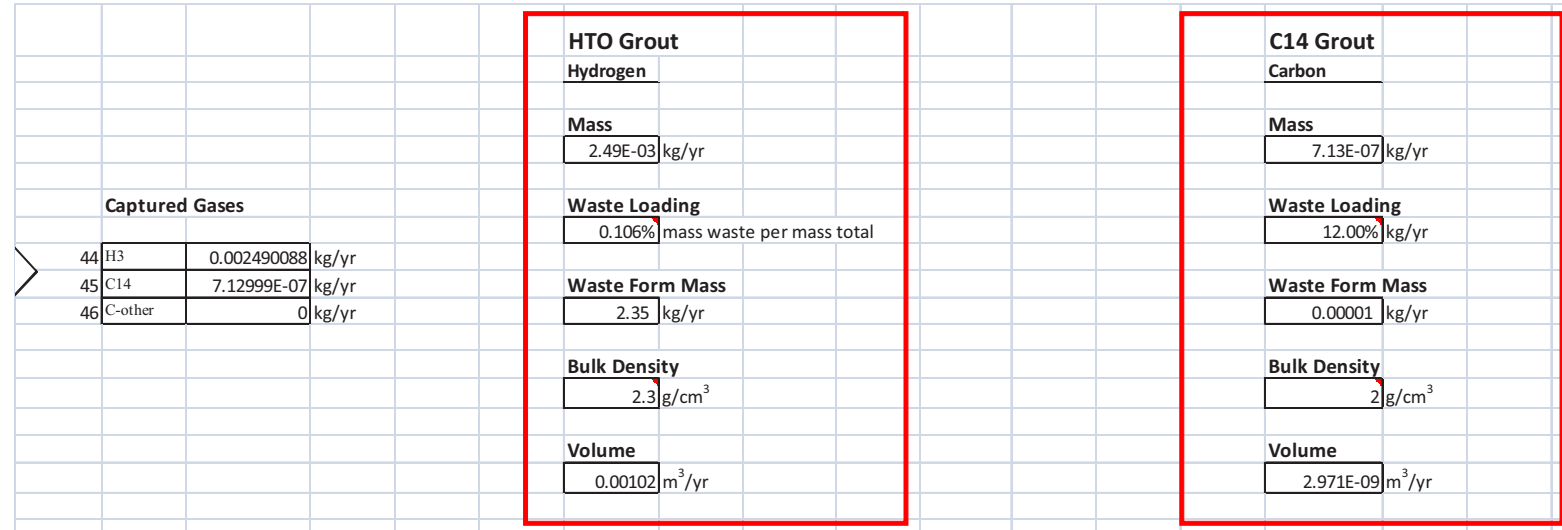

Figure 4-2. Illustration of the tritium and C-14 waste form output page on worksheet Grout in the model.

In most of the other waste stream cases, the isotopic content is tracked from the separations processes based on the separation factors for all the different isotopes and elements tracked in FIT. For the glass waste form, a glass model from the Waste Form Campaign [Ryan 2009] is executed in FIT to estimate waste loading (see Figure 4-3).

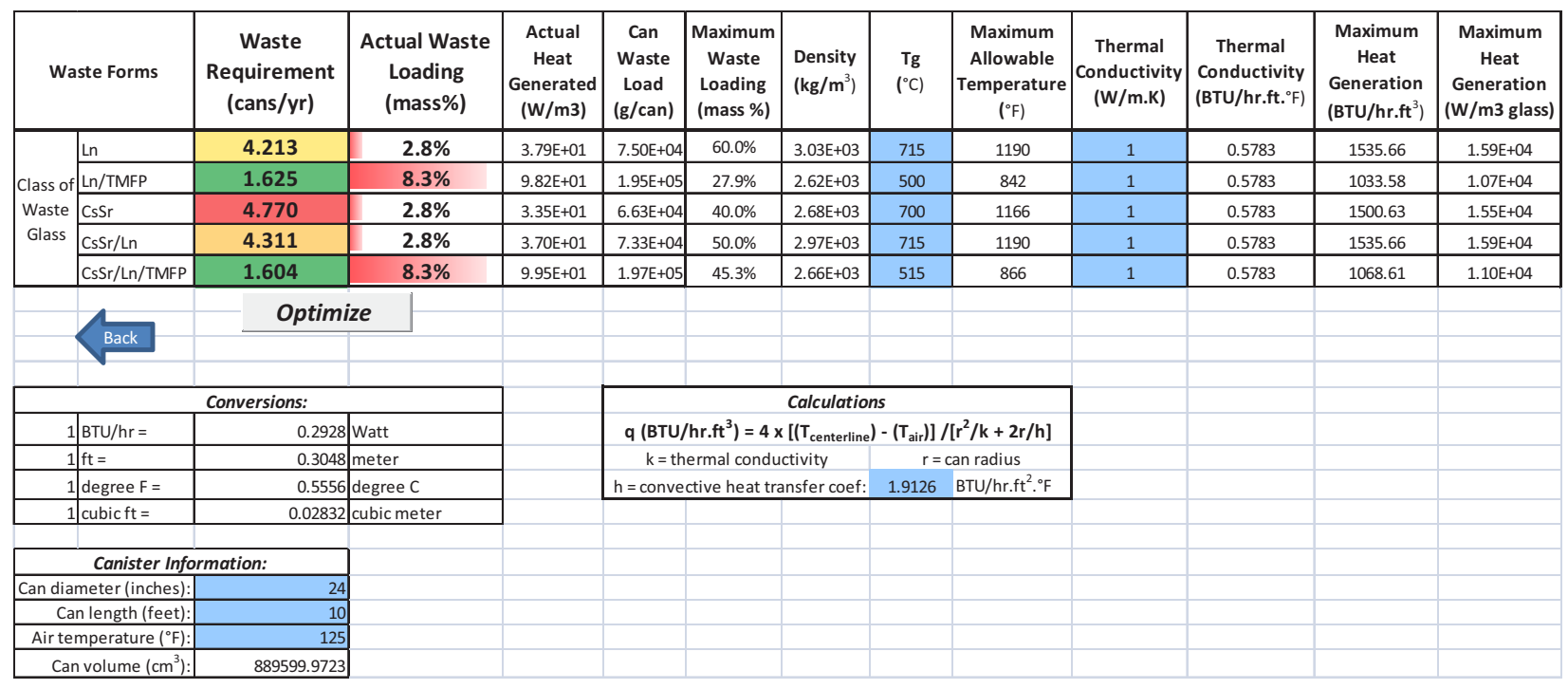

Figure 4-3. Glass waste form model execution calculation worksheet OUTPUT- \& Assumptions_WP.

\subsection{Other Information in MrTauWinery Excel2007 File}

Worksheet Calc input adj (FP) has the calculated " $k$ " value for the targeted or reference composition of the reactor and fuel in the recycle loop. This worksheet can also be consulted to determine how much of the neutron absorption or fissions come from which element.

Worksheet available uranium has the RU-1 and RU-2 compositions in the last iteration of FIT. 


\section{FUTURE WORK}

We invite feedback and suggestions for future work. Of course, plans must evolve as program priorities and budgets change.

FIT should calculate the supply of RU-1 and RU-2 and FIT should not use more than in supply.

In addition to providing the mass of flows in and out of fuel fabrication, FIT should calculate the heat, gamma, neutron emission, and radiotoxicity(inhalation). This is straightforward.

The waste processing module needs further refinement and review. There are missing pieces of data that need a referenceable source.

We should add data quality indicators to the data we have and any new data, likely on a 1-5 scale:

1. Source of data is industrial-scale testing or operation

2. Source of data is pilot-scale testing or operation

3. Source of data is continuous lab-scale testing or operation

4. Source of data is batch lab-scale testing or operation

5. Source of data is estimates from subject matter experts, averages from other elements, or default values).

We should make it easier to add more reactor/fuel composition cases.

The input and data matrices should be adjusted so that as data on impurities from processing are available, they can be added.

Economic calculations could be added to FIT.

After gathering more data, we could add a calculation of the number of containers to waste output.

Various additives for each separation process still need to be gathered and entered into the model (solvents, salts, etc, especially for electrochemical).

We could add a suite of standard analysis graphs as an automatic output from FIT so that the users do not have to generate their own output graphs manually.

\subsection{Fuel Options}

Add an option for enriched uranium (EU).

Add an option for natural uranium (NU).

Add an option to turn off the separation-1 stream (as required for a breeder calculation).

Add thorium fuel cycles as an option, this would require an update to MrTau.

Develop and test an "optimizer" or "solver" that would iteratively and automatically run the mass flow engine to balance criteria or to meet a particular criterion. 


\subsection{Waste Characterization}

At present, the user may select a waste classification for each waste stream. This has two problems. First, the model uses current waste classification names.

Second, it does not allow for different classification for waste streams on the basis of changing criteria or changing waste stream composition. We should replace the manual waste classification with one that asks users for the criteria to judge waste classification and then have FIT automatically assign each waste stream on the basis of its composition. Possibilities include the following:

$0<100 \mathrm{nCi}$ of alpha-emitting TRU (halflife greater than 20 years) per gram of waste - per 40CFR191

$\circ<100 \mathrm{nCi}$ of alpha-emitting TRU (halflife greater than 5 years) per gram of waste - per 10CFR61

- Specific isotope concentration limits $\left(\mathrm{Ci} / \mathrm{g}\right.$ or $\left.\mathrm{Ci} / \mathrm{m}^{3}\right)$ in $10 \mathrm{CFR} 61$, defining low-level waste class C suitable for near-surface burial in 10CFR61.

- Specific isotope concentration limits $(\mathrm{Ci} / \mathrm{g})$ extended to other isotopes not in 10CFR61 by S. A. Fetter [Fetter1988, Fetter1990]

- Heat limitation (W/kg of waste form, $\mathrm{W} / \mathrm{m}^{3}$ of waste form, or $\mathrm{W} / \mathrm{m}^{3}$ of packaged waste) as suggested by Kocher and Croff [Kocher1987] and the Nuclear Energy Agency [NEAR2006] as a possible characteristic-based dividing line between waste classes.

$2000 \mathrm{~W} / \mathrm{m}^{3}$ - apparently based on long-term geologic disposal complications [NEA2006]

$50 \mathrm{~W} / \mathrm{m}^{3}$ - based on heat complications in near-surface burial situations [Kocher1987]

$700 \mathrm{Ci} / \mathrm{m}^{3}$ for all isotopes with halflife less than 5 years [10CFR61]. This is intended to guard against excessive difficulties from contact dose or heat during handling and emplacement of the waste.

- IAEA waste classification schemes.

The above examples illustrate the complexity of this task because there are different possible criteria, expressed in different units. But, it also shows the potential value for automating the task. In theory, as the losses of TRU into waste are small, there may be no waste that is simultaneously high-heat and high longevity for radiotoxicity.

Table 5-1 shows how radioactive wastes might be considered based on their levels of decay heat (which challenges the durability and performance of the waste form, waste packaging, storage sites, and longterm disposal systems) and long-term radiotoxicity (which indicates the hazard that needs to be isolated by the waste form, waste packaging, storage sites, and disposal sites). 
Table 5-1. Radioactive waste characterization based on decay heat and long-term radiotoxicity (Bays 2010c).

\begin{tabular}{|l|l|l|}
\hline $\begin{array}{l}\text { High } \\
\text { Heat }\end{array}$ & $\begin{array}{l}|c| \\
\text { Example isotopes: Transuranics (and Trans- } \\
\text { thorium). } \\
\text { Expected disposition: Deep geological disposal, } \\
\text { none of which presently exist. }\end{array}$ & $\begin{array}{l}\text { Low Long-Term Radiotoxicity } \\
\text { Example disposition: de facto decay } \\
\text { during storage of used fuel in the U.S. } \\
\text { while the fuel awaits either final disposal. }\end{array}$ \\
\hline $\begin{array}{l}\text { Low } \\
\text { Heat }\end{array}$ & $\begin{array}{l}\text { Example isotopes: }{ }^{14} \mathrm{C},{ }^{99} \mathrm{Tc},{ }^{129} \mathrm{I} . \\
\text { Example disposition: Waste entombed in } \\
\text { Kecommissioned U.S. nuclear facilities, German }{ }^{85} \mathrm{Kr},{ }^{137} \mathrm{Cs},{ }^{90} \mathrm{Sr} .\end{array}$ \\
$\begin{array}{l}\text { Konrad Mine. } \\
\text { Example isotopes: Shorter lived fission } \\
\text { products in low concentrations. }\end{array}$ \\
$\begin{array}{l}\text { Example disposition: Shallow land burial } \\
\text { in the U.S. of waste that meets current } \\
\text { Class A, B, or C LLW limits. }\end{array}$ \\
\hline
\end{tabular}

High decay heat, high long-term radiotoxicity wastes (such as spent nuclear fuel, and waste streams from separating used fuels that contain the majority of fission products and TRU isotopes that are not recycled) are those wastes that would require disposal in geologic repository systems that will isolate these wastes from the environment for geological timeframes. Such repositories do not yet exist in the U.S. so there is presently considerable uncertainty in how we will isolate these waste streams, which is an issue for the public acceptance of the nuclear fuel cycle.

High decay heat, but low long-term radiotoxicity wastes could include some waste streams that contain relatively short-lived fission products such as ${ }^{3} \mathrm{H},{ }^{85} \mathrm{Kr},{ }^{139} \mathrm{Cs}$, and ${ }^{90} \mathrm{Sr}$, separated from used fuel (and other, long-lived isotopes) in some potential separations processes. These waste streams might be best disposed through a combination of a decay storage for time duration long enough so that levels of residual radionuclides meet Class A, B, or C LLW or mixed LLW concentration limits, after which they can be disposed at relatively low cost as low-heat, low radiotoxicity, low-risk wastes. Uncertainty, cost, and risk in how these wastes can be disposed are lower than for high heat, high radiotoxicity wastes. The current de facto decay during storage of used fuel in the U.S. for up to 50 years (and more every year that storage continues), while the fuel awaits either final disposal or closure of the nuclear fuel cycle, provides a precedent for this approach, which has gained public and regulatory acceptance. MIT 2010 recommends storage of used fuel for about 100 years to allow decay of short-lived isotopes.

Low decay heat, but high long-term radiotoxicity wastes could include some wastes presently classified as GTCC, and waste streams that contain minor actinides that are separated from used fuel but not recycled for some fuel cycle options. These kinds of waste streams, (following decay storage of shortlived isotopes, if needed) may still require isolation for geological timeframes, but not necessarily in waste forms, packages, and disposal sites that are designed to tolerate high decay heat. Uncertainty, cost, and risk in how these wastes can be disposed are lower than for high heat, high radiotoxicity wastes. Precedents of how these types of wastes are disposed exist in the U.S. and other countries (such as entombment of radioactive materials in decommissioned and buried DOE facilities, and the Waste Isolation Pilot Plant in the U.S., and the Konrad Mine in Germany [Bandt2003, Sailer2008]). 
Low decay heat, low radiotoxicity wastes could include waste streams now classified under current regulations as Class A, B, or C LLW. Existing LLW disposal sites are precedents of safe and relatively low cost disposal of these kinds of wastes in the U.S. and other countries.

\subsubsection{Fuel impurity limits}

At present, the user must manually compare fuel composition with postulated fuel impurity limits. One could automate this process by asking the user to supply fuel impurity limits and then automatically comparing them. This has one major complication, which is that until and unless there are data for all elements in a limited chemical group, it could be seriously misleading. For example, consider a limit on all halogens. $\mathrm{F}$ and $\mathrm{Cl}$ are present only from processing impurities. $\mathrm{Br}$ and I will be present because they are fission products; they could also arise as processing impurities. If there are no data on process-source impurities, then comparing $\mathrm{Br}$ and I to the total halogen limit (and finding it acceptable) could give a false sense of security.

Another complication with fuel impurity limits is that the rationale for impurity limits varies.

Furthermore, if a design fix were implemented to relax one of the limits, there could be another limit that would come into play, i.e., it would not be appropriate to assume the element would become unlimited. For example, consider a limit on lanthanides because of their impact on fuel-cladding interactions. This limit would be relaxed or eliminated if a new cladding or barrier between fuel and cladding were added (with attendant costs); but rather than become unlimited, the lanthanides might then become limited by some other consideration.

The relevance to FIT is that we may invite the user to separately input a limit based on one or more of the above categories of constraints. Then, allow the user to deactivate all the limits of a given category in which case the remaining limits would apply.

FIT assumes that impurities are carried through the fabrication process, but for separations that do not remove fission products, separation of a number of impurities will take place in either melting or sintering processes. This assumption of impurities remaining in the fuel during fuel fabrication is only good at historical impurity levels. 


\section{REFERENCES}

10 CFR 60

10 CFR 61

10 CFR 63

40 CFR 191

Alfonsi2011

Bandt 2003

Bays2009

Bays2010a

Bays2010b

Bays2010c

Christian 1999

DOE1988
Nuclear Regulatory Commission, "Disposal of High-Level Radioactive Wastes in Geologic Repositories," Title 10, Part 60 of the Code of Federal Regulations, revised as of 2002 .

Nuclear Regulatory Commission, "Licensing Requirements for Land Disposal of Radioactive Waste," Title 10, Part 61 of the Code of Federal Regulations, revised as of 2002.

Nuclear Regulatory Commission, "Disposal of High-Level Radioactive Wastes in a Geologic Repository at Yucca Mountain, Nevada," Title 10, Part 63 of the Code of Federal Regulations, revised as of 2002.

Environmental Protection Agency, "Environmental Radiation Protection Standards for Management and Disposal of Spent Nuclear Fuel, High-Level and Transuranic Radioactive Wastes," Title 40, Part 191 of the Code of Federal Regulations, revised as of 2002.

Andrea Alfonsi, Samuel E. Bays, Cristian Rabiti, Steven J. Piet, "Multi-Reactor Transmutation Analysis Utility (MRTAU, $\alpha 1$ ): Verification," INL/EXT-1121384, February 2011.

Gabriele Bandt, B. Posnatzki, K. Beckers, "Final Disposal of Radioactive Waste in Germany: Plan for Approval Process of Konrad Mine and Acceptance Requirements," Waste Management 2003 Conference, February 23-27, 2003.

S. E. Bays, S. J. Piet, M. Pope, G. Youinou, G. Dumontier, D. Hawn, "Transmutation Dynamics: Impacts of Multi-Recycling on Fuel Cycle Performances," INL/EXT-09-16857, AFCI-SYSA-PMO-MI-DV-2009-000185, September 2009.

Samuel E. Bays, Steven J. Piet, Kurt G. Vedros, Alex C. Chambers, "INL FY 2010 Transmutation Studies," FCR\&D-SYSA-2010-000103, July 21, 2010.

Samuel Bays, Steven Piet, Amaury Dumontier, Fuel Cycle Isotope Evolution by Transmutation Dynamics over Multiple Recycles, Proceedings of ICAPP '10, San Diego, CA, USA, June13-17, 2010.

S. E. Bays, S. J. Piet, N. R. Soelberg, M. Lineberry, and B. W. Dixon, "Technology Informed Perspectives: Analysis Framework for Nuclear Fuel Cycle Concepts," FCRD-SYSA-2010-000184, INL/EXT-19977, September 30, 2010.

Jerry D. Christian, James W. Sterbentz, David G. Abbott, Dieter A. Knecht, Ivan R. Thomas, Norman E. Stanley, Chris S. Staley, Michael L. Croson, Richard J. Cacciapouti, G. M. Solan, M. C. Beganski, A. P. Fyfe, Herbert Feinroth, Bernard Hao, Kenneth R. Czerwinski, M. P. Reynard, Kevin P. Carney, "Dry Recycle of Spent Nuclear Fuel,” LDRD Project 99-292, December 1999.

DOE, "Radioactive Waste Management," DOE Order 5820.2A, Washington, DC, September 26, 1988. 
DOE2007

Fetter1988

Fetter1990

Hesson1963

Hoffman2010

Jacobson2009

Jacobson2010

Kocher1987

MIT2010

NEA2002

NEA2006

NRC1987

NRC2001

NRC 2009

NWPA1982
DOE, "Product Solidification, Waste Solidification, and Off-Gas Unit Operations Mass Balance Basis, Advanced Fuel Cycle Facility Project," GNEP-AFCFWAST-PC-RT-2007-000332, Rev Draft A, September 27, 2007.

S. Fetter, E. T. Cheng, F. M. Mann, "Long-Term Radioactivity in Fusion Reactors," Fusion Engineering and Design, 6, 1988, pp. 123-130.

S. Fetter, E. T. Cheng, F. M. Mann, "Long-Term Radioactive Waste from Fusion Reactors: Part II," Fusion Engineering and Design, 13, 1990, pp. 239-248.

J. C. Hesson, M. J. Feldman, and L. Burris, "Description and Proposed Operation of the Fuel Cycle Facility for the Second Experimental Breeder Reactor (EBRII)," ANL-6605, April 1963.

Edward A Hoffman, "ANL FY10 Transmutation Studies," ANL-FCRD-307, July $2,2010$.

J. J. Jacobson, A. M. Yacout, G. E. Matthern, S. J. Piet, D. E. Shropshire, "Verifiable Fuel Cycle Simulation (VISION) Model," paper 9312, Global 2009, Paris, France, September, 2009.

J. J. Jacobson, A. M. Yacout, G. E. Matthern, S. J. Piet, D. E. Shropshire, R. F. Jeffers, T. Schweitzer, "Verifiable Fuel Cycle Simulation Model (VISION): A Tool for Analyzing Nuclear Fuel Cycle Futures," Nuclear Technology, November, 2010.

D. C. Kocher and A. G. Croff, "A Proposed Classification System for HighLevel and Other Radioactive Wastes," ORNL/TM-10289, June 1987,

MIT Nuclear Fuel Cycle Study Advisory Committee, "The Future of the Nuclear Fuel Cycle," ISBN 978-0-9828008-1-2, 2010.

Nuclear Energy Agency, The Handling of Timescales in Assessing Post-closure Safety of Deep Geological Repositories, Workshop Proceedings, Paris, France, April 16-18, 2002.

Nuclear Energy Agency, "Advanced Nuclear Fuel Cycles and Radioactive Waste Management," Organisation for Economic Co-Operation and Development, NEA No. 5990, 2006.

Nuclear Regulatory Commission, Definition of "High-Level Radioactive Waste, Advanced Notice of Proposed Rulemaking," Federal Register, Volume 52, No. 39, February 27, 1987.

Nuclear Regulatory Commission, Code of Federal Regulations, "Waste Classification," 10 CFR 61.55, 2001.

Nuclear Regulatory Commission, Code of Federal Regulations, "Disposal of High-Level Radioactive Wastes in a Geologic Repository at Yucca Mountain, Nevada," 10 CFR 63, 2009.

Nuclear Waste Policy Act of 1982, 96 Statutes at large 2201, 42 U.S. Code 10101 et seq. Amendments of 1987. 
Pereira2010

Piet $2009 b$

Piet2009a

Piet2010b

Piet2010a

Piet2010b

Piet2010c

Ryan2009

Sailer2008

Shropshire2009

Soelberg2009

Soelberg2010

Yee2008
Candido Pereira, Argonne National Laboratory, Personal communication to Layne Pincock, Idaho National Laboratory, May 27, 2010.

Steven J. Piet, David E. Shropshire, Nick Soelberg (INL), "Must Advanced Fuel Cycles Produce High-Level Waste?," Integrated Radioactive Waste Management in Future Fuel Cycles, November 8-12, 2009, Charleston, South Carolina.

S. J. Piet, Selection of Isotopes and Elements for Fuel Cycle Analysis, "Advances In Nuclear Fuel Management IV (ANFM IV)," April 12-15, 2009, INL/CON-0815050 .

Steven J. Piet, Nick R. Soelberg, Samuel E. Bays, Robert S. Cherry, Denia Djokić, Candido Pereira, Layne F. Pincock, Eric L. Shaber, Melissa C. Teague, Gregory M. Teske, Kurt G. Vedros, "System Losses Study - FIT (Fuel-cycle Integration \& Tradeoffs), FCRD-SYSA-2010-000140, September 15, 2010.

Steven J. Piet, Samuel E. Bays, Edward A. Hoffman, "Description of Transmutation Library for Fuel Cycle System Analyses," FCRD-SYSA-2010000116, INL/EXT-10-19545, August 4, 2010.

Steven J. Piet, Nick R. Soelberg, Samuel E. Bays, Robert S. Cherry, Denia Djokić, Candido Pereira, Layne F. Pincock, Eric L. Shaber, Melissa C. Teague, Gregory M. Teske, Kurt G. Vedros, "System Losses Study - FIT (Fuel-cycle Integration \& Tradeoffs), FCRD-SYSA-2010-000140, September 15, 2010.

Steven J. Piet, Nick R. Soelberg, Samuel E. Bays, Candido Pereira, Layne F. Pincock, Eric L. Shaber, Melissa C. Teague, Gregory M. Teske, Kurt Vedros, "The FIT Model - Fuel-cycle Integration and Tradeoffs," FCR\&D-SYSA-2010000192, INL/EXT-10-20190, September 30, 2010.

Joseph Ryan, "Complete Model for Glass Waste Form Volume vs. Key Process Parameters," Pacific Northwest National Laboratory, September 4, 2009.

Michael Sailer, "Nuclear Waste Repository Case Studies: Germany," Bulletin of the Atomic Scientists, 2008).

D. E. Shropshire, S. J. Piet, N. Soelberg, R. Cherry, R. Henry, D. Meikrantz, G. Teske, C. Pereira, E. Shaber, "System Losses and Assessment Trade Study," AFCI-SYSA-PMO-MI-DV-2009-000203, INL/EXT-09-16891, September 30, 2009.

Nick Soelberg, Ted Bauer, Mark Nutt, Joe Carter, Dirk Gombert, Steve Priebe, Steve Piet, and Denia Djokic, "Managing Heat and Radiotoxicity of Spent Nuclear Fuel," Integrated Radioactive Waste Management in Nuclear Fuel Cycles, Charleston, SC, November 8-12, 2009.

N. R. Soelberg, S. J. Piet, S. E. Bays, R. N. Henry, D. H. Meikrantz, T. A. Taiwo, T. K. Kim, D. Yun, J. Gehin, L. Qualls, K. Williams, W. Halsey, "Status Report Waste Stream Analysis for Nuclear Fuel Cycles,” April 15, 2010.

S. K. Yee, "Nuclear Fuel Cycle Modeling Approaches for Recycling and Transmutation of Spent Nuclear Fuel," Masters Thesis, Ohio State University, 2008. 
This page intentionally left blank. 
Appendix A

\section{Working-Value Separation Factors}


This page intentionally left blank. 


\section{A.1 Current Status of Working-Value Separation Factors}

The separation factors used in FIT are a combination of (typically very limited) separations data, extrapolations of known separations data for some elements to other elements that could be expected to behave the same way for that separations process, and assumptions or default values for elements where we are not sure how they behave relative to known separations factors for other elements. The user should be wary to inspect and adapt the separations factors as necessary for the objectives of the FIT case they are performing.

We have updated many of the separation factors in FIT 2.0, to (a) account for new information and interpretations that were not included in the earlier version, and (b) to include separation factors for individual elements that were grouped together in FIT 1.0. The tables in the following Appendix A subsections show the old and new separation factors for FIT 1.0 and 2.0. Examples of some items that have been recently addressed include:

- Separation factors for $\mathrm{Ne}$ and $\mathrm{Ar}$ have been set equal to $\mathrm{Kr}$ for all separations cases. At this time there is no $\mathrm{Ne}$ or $\mathrm{Ar}$ in the used fuel inputs. A future FIT version may account for the potential for tramp Ar and $\mathrm{Ne}$ in air inleakage or process air.

- The Br separation factor in UREX+1 was set equal to that for iodine in all separations cases for consistency.

- So far, the partitioning of elements in all of the separations processes except for UREX+1 is bimodal, even when there are more than 2 output streams. Although we are generally avoiding $0 \%$ and $100 \%$ separations values by using default values of $0.1 \%$ and $99.9 \%$ in these bimodal distributions, we still (by default, when we don't enter a partitioning value) are allowing $0 \%$ partitioning to those other output streams. Perhaps this could be re-evaluated in future model revisions.

- In melt refining, the Group 1 elements $\mathrm{Li}, \mathrm{Na}$, and $\mathrm{K}$ partitioning was set to $0.1 \%$ to the TRU+U product to be consistent with the $\mathrm{Cs}$ and $\mathrm{Rb}$ partitioning.

- In melt refining, Group 2 elements $\mathrm{Be}, \mathrm{Mg}$, and Ca partitioning was set at $5 \%$ to the TRU+U stream, consistent with Sr partitioning (but $0.1 \%$ partitioning of Ba to the TRU+U was unchanged, which is inconsistent and incorrect based on Hesson 1993; perhaps it could be made consistent in future uses of the model).

- In AIROX, Group 1 element partitioning was set to $0.1 \%$ to the TRU+U product; Group 2 element partitioning was set to $99.9 \%$ to the TRU+U product.

- Rules for Echem separations have been updated, mainly due to addition of elements that were grouped in FIT 1.0. The main focus has addressed what elements do not dissolve and so stay with the cladding in a metal waste form (all transition metals except for some $\mathrm{Zr}$ that goes to the $\mathrm{U}$ product, and all semimetals including Te); and what elements dissolve and partition to the salt waste form (Group 1, Group 2, and lanthanides).

- The separations factors for UREX+1 are more complex and so have some internal inconsistencies at this time. For example, the partitioning of Cs (a Group 1 element) equals that of Sr (a Group 2 element), which seems inconsistent if we expect that Group 1 and 2 elements might behave 
differently. In addition, some the data for the lanthanides is inconsistent, probably because of different empirical determinations of different lanthanides or groups of lanthanides.

\section{A.2 UREX+1a Separation Factors - FIT 2.0 Updates from FIT 1.0}

The first table (Table A1) shows the old separation factors. Note that individual transition metal isotopes (Se-79, Ru-106, Pd-107, Cd-113m, Sn-126, Sb-125) were set to the best data for their chemical elements. However, the rest of the mass of these elements were grouped into either the glass-form-constraining elements Mo-Ru-Rh-Pd or the catch-all "transition metals". The second table (Table A2) shows the separation factors for FIT 2.0, in which there are no "catch-all" groupings of elements.

Table A1. FIT 1.0 Working-Value Separation Factors for UREX+1a Separation.

\begin{tabular}{|c|c|c|c|c|c|c|c|c|c|}
\hline & $\begin{array}{c}\text { Recovered } \\
\mathrm{U}\end{array}$ & $\begin{array}{l}\text { U-TRU } \\
\text { Product }\end{array}$ & $\begin{array}{c}\text { Captured } \\
\text { Gases }\end{array}$ & $\begin{array}{l}\text { Effluents } \\
\text { Released }\end{array}$ & Technetium & Cs-Sr & Lanthinides & UDS & $\begin{array}{l}\text { Raffinate/ } \\
\text { Residual }\end{array}$ \\
\hline $\mathrm{H}$ & & & $99.0 \%$ & $1.0 \%$ & & & & & \\
\hline C & & & $90.0 \%$ & $10.0 \%$ & & & & & \\
\hline Inert gases & & & $99.0 \%$ & $1.0 \%$ & & & & & \\
\hline Se79 & $0.10 \%$ & $0.10 \%$ & & & & $0.10 \%$ & $0.00 \%$ & $1 \%$ & $98.70 \%$ \\
\hline $\mathrm{Rb}$ & $0.10 \%$ & $0.00 \%$ & & & & $98.80 \%$ & $0.00 \%$ & $1 \%$ & $0.10 \%$ \\
\hline $\mathrm{Sr}$ & $0.40 \%$ & $0.55 \%$ & & & & $97.76 \%$ & $0.23 \%$ & $1 \%$ & $0.07 \%$ \\
\hline$Z r$ & $0.40 \%$ & $0.39 \%$ & & & & $1.01 \%$ & $0.00 \%$ & $1 \%$ & $97.21 \%$ \\
\hline Tc & & $0.70 \%$ & & & $94.55 \%$ & $0.22 \%$ & $0.00 \%$ & $1 \%$ & $3.53 \%$ \\
\hline Ru106 & $2.08 \%$ & $4.89 \%$ & & & & $6.20 \%$ & $0.00 \%$ & $1 \%$ & $85.82 \%$ \\
\hline Pd107 & $5.35 \%$ & $14.55 \%$ & & & & $14.80 \%$ & $3.43 \%$ & $1 \%$ & $60.88 \%$ \\
\hline Mo-Ru-Rh-Pd & $1.58 \%$ & $0.88 \%$ & & & & $54.72 \%$ & $0.19 \%$ & $1 \%$ & $41.63 \%$ \\
\hline Cd113m & $0.10 \%$ & $0.09 \%$ & & & & $9.79 \%$ & $0.00 \%$ & $1 \%$ & $89.02 \%$ \\
\hline Sn126 & $45.44 \%$ & $18.44 \%$ & & & & $0.05 \%$ & $0.02 \%$ & $1 \%$ & $35.05 \%$ \\
\hline Sb125 & $7.62 \%$ & $3.13 \%$ & & & & $76.85 \%$ & $3.29 \%$ & $1 \%$ & $8.11 \%$ \\
\hline Transition metals & $0.10 \%$ & $0.10 \%$ & & & & $0.10 \%$ & $0.00 \%$ & $1 \%$ & $98.70 \%$ \\
\hline Halogens & & & $100.00 \%$ & $0.00 \%$ & & & & & \\
\hline Cs & $0.40 \%$ & $0.03 \%$ & & & & $98.46 \%$ & $0.00 \%$ & $1 \%$ & $0.11 \%$ \\
\hline $\mathrm{Ba}$ & $0.05 \%$ & $0.19 \%$ & & & & $98.55 \%$ & $0.20 \%$ & $1 \%$ & $0.00 \%$ \\
\hline Lanthanides & $0.10 \%$ & $0.03 \%$ & & & & $0.07 \%$ & $98.71 \%$ & $1 \%$ & $0.09 \%$ \\
\hline $\mathrm{Ac}, \mathrm{Th}, \mathrm{Pa}$ & $0.08 \%$ & $98.89 \%$ & & & & $0.03 \%$ & $0.00 \%$ & $1 \%$ & $0.00 \%$ \\
\hline U & $99.00 \%$ & $0.00 \%$ & & & & $0.00 \%$ & $0.00 \%$ & $1 \%$ & $0.00 \%$ \\
\hline $\mathrm{Np}$ & $1.78 \%$ & $97.19 \%$ & & & & $0.02 \%$ & $0.00 \%$ & $1 \%$ & $0.00 \%$ \\
\hline $\mathrm{Pu}$ & $0.00 \%$ & $98.96 \%$ & & & & $0.03 \%$ & $0.00 \%$ & $1 \%$ & $0.00 \%$ \\
\hline $\mathrm{Am}, \mathrm{Cm}, \mathrm{Bk}, \mathrm{Cf}$ & $0.08 \%$ & $98.89 \%$ & & & & $0.03 \%$ & $0.00 \%$ & $1 \%$ & $0.00 \%$ \\
\hline
\end{tabular}


Table A2. FIT 2.0 Working-Value Separation Factors for UREX+1a Separation.

\begin{tabular}{|c|c|c|c|c|c|c|c|c|c|}
\hline & $\begin{array}{c}\text { Recovered } \\
U\end{array}$ & \begin{tabular}{c|} 
U-TRU \\
Product
\end{tabular} & $\begin{array}{c}\text { Captured } \\
\text { Gases }\end{array}$ & $\begin{array}{l}\text { Effluents } \\
\text { Released }\end{array}$ & $\begin{array}{c}\text { Technetiu } \\
\text { m }\end{array}$ & Cs-Sr & Lanthanides & UDS & \begin{tabular}{|c|} 
Raffinatel \\
Residual
\end{tabular} \\
\hline $\mathrm{H}$ & $0.0000 \%$ & $0.000 \%$ & $99.00 \%$ & $1.00 \%$ & & $0.000 \%$ & $0.0000 \%$ & & $0.000 \%$ \\
\hline C & $0.0000 \%$ & $0.000 \%$ & $90.00 \%$ & $10.00 \%$ & & $0.000 \%$ & $0.0000 \%$ & & $0.000 \%$ \\
\hline Inert gases & $0.0000 \%$ & $0.000 \%$ & $99.00 \%$ & $1.00 \%$ & & $0.000 \%$ & $0.0000 \%$ & & $0.000 \%$ \\
\hline Se & $0.0990 \%$ & $0.099 \%$ & & & & $0.099 \%$ & $0.0001 \%$ & $1 \%$ & $98.703 \%$ \\
\hline $\mathrm{Rb}$ & $0.0990 \%$ & $0.000 \%$ & & & & $98.802 \%$ & $0.0000 \%$ & $1 \%$ & $0.099 \%$ \\
\hline $\mathrm{Sr}$ & $0.3960 \%$ & $0.547 \%$ & & & & $97.756 \%$ & $0.2322 \%$ & $1 \%$ & $0.069 \%$ \\
\hline$Z r$ & $0.3960 \%$ & $0.390 \%$ & & & & $1.006 \%$ & $0.0004 \%$ & $1 \%$ & $97.208 \%$ \\
\hline $\mathrm{Nb}$ & $2.3760 \%$ & $3.447 \%$ & & & & $0.773 \%$ & $0.0035 \%$ & $1 \%$ & $92.400 \%$ \\
\hline Mo & $2.3760 \%$ & $3.447 \%$ & & & & $0.773 \%$ & $0.0035 \%$ & $1 \%$ & $92.400 \%$ \\
\hline Tc & & $0.703 \%$ & & & $94.545 \%$ & $0.218 \%$ & $0.0007 \%$ & $1 \%$ & $3.533 \%$ \\
\hline $\mathrm{Ru}$ & $2.0790 \%$ & $4.894 \%$ & & & & $6.203 \%$ & $0.0049 \%$ & $1 \%$ & $85.819 \%$ \\
\hline $\operatorname{Re}$ & $0.2970 \%$ & $0.196 \%$ & & & & $0.849 \%$ & $0.0002 \%$ & $1 \%$ & $97.658 \%$ \\
\hline $\mathrm{Pd}$ & $5.3460 \%$ & $14.545 \%$ & & & & $14.797 \%$ & $3.4341 \%$ & $1 \%$ & $60.877 \%$ \\
\hline $\mathrm{Ag}$ & $2.1780 \%$ & $0.066 \%$ & & & & $15.298 \%$ & $0.0156 \%$ & $1 \%$ & $81.443 \%$ \\
\hline $\mathrm{Cd}$ & $0.0990 \%$ & $0.089 \%$ & & & & $9.791 \%$ & $0.0001 \%$ & $1 \%$ & $89.021 \%$ \\
\hline In & $0.1386 \%$ & $0.093 \%$ & & & & $5.833 \%$ & $0.0001 \%$ & $1 \%$ & $92.936 \%$ \\
\hline Sn & $45.4410 \%$ & $18.441 \%$ & & & & $0.054 \%$ & $0.0185 \%$ & $1 \%$ & $35.046 \%$ \\
\hline $\mathrm{Sb}$ & $7.6230 \%$ & $3.127 \%$ & & & & $76.848 \%$ & $3.2944 \%$ & $1 \%$ & $8.107 \%$ \\
\hline $\mathrm{Te}$ & $5.1480 \%$ & $0.092 \%$ & & & & $1.595 \%$ & $0.0001 \%$ & $1 \%$ & $92.164 \%$ \\
\hline Halogens & $0.0000 \%$ & $0.000 \%$ & $99.999 \%$ & $0.0010 \%$ & & $0.000 \%$ & $0.0000 \%$ & & $0.000 \%$ \\
\hline Cs & $0.3960 \%$ & $0.034 \%$ & & & & $98.456 \%$ & $0.0000 \%$ & $1 \%$ & $0.114 \%$ \\
\hline $\mathrm{Ba}$ & $0.0495 \%$ & $0.193 \%$ & & & & $98.555 \%$ & $0.2028 \%$ & $1 \%$ & $0.000 \%$ \\
\hline Y, La to Ho & $0.0990 \%$ & $0.099 \%$ & & & & $0.099 \%$ & $98.6046 \%$ & $1 \%$ & $0.099 \%$ \\
\hline Er to $\mathrm{Yb}$ & $0.0990 \%$ & $0.030 \%$ & & & & $0.069 \%$ & $98.7132 \%$ & $1 \%$ & $0.089 \%$ \\
\hline Ac & $0.0792 \%$ & $98.885 \%$ & & & & $0.030 \%$ & $0.0020 \%$ & $1 \%$ & $0.004 \%$ \\
\hline Th & $0.0792 \%$ & $98.885 \%$ & & & & $0.030 \%$ & $0.0020 \%$ & $1 \%$ & $0.004 \%$ \\
\hline $\mathrm{Pa}$ & $0.0792 \%$ & $98.885 \%$ & & & & $0.030 \%$ & $0.0020 \%$ & $1 \%$ & $0.004 \%$ \\
\hline $\mathrm{U}$ & $98.9970 \%$ & $0.000 \%$ & & & & $0.003 \%$ & $0.0000 \%$ & $1 \%$ & $0.000 \%$ \\
\hline $\mathrm{Np}$ & $1.7820 \%$ & $97.193 \%$ & & & & $0.019 \%$ & $0.0008 \%$ & $1 \%$ & $0.005 \%$ \\
\hline $\mathrm{Pu}$ & $0.0003 \%$ & $98.963 \%$ & & & & $0.030 \%$ & $0.0020 \%$ & $1 \%$ & $0.005 \%$ \\
\hline $\mathrm{Am}, \mathrm{Cm}, \mathrm{Bk}, \mathrm{Cf}$ & $0.0792 \%$ & $98.885 \%$ & & & & $0.030 \%$ & $0.0020 \%$ & $1 \%$ & $0.004 \%$ \\
\hline
\end{tabular}

\section{A.3 Echem Separation Factors - FIT 2.0 Updates from FIT 1.0}

Tables A3 and A4 show the FIT 1 and FIT 2 separation factors for electrochemical separation, respectively. Note that all the transition metals (except $\mathrm{Zr}$ ) are assigned the same separation factors. 
Table A3. FIT 1.0 Working-Value Separation Factors for Electrochemical Separation.

\begin{tabular}{|c|c|c|c|c|c|c|}
\hline & $\begin{array}{c}\text { Recovered } \\
U\end{array}$ & $\begin{array}{l}\text { U-TRU } \\
\text { Product }\end{array}$ & $\begin{array}{c}\text { Captured } \\
\text { Gases }\end{array}$ & $\begin{array}{l}\text { Effluents } \\
\text { Released }\end{array}$ & $\begin{array}{c}\text { Cladding/ } \\
\text { Coating }\end{array}$ & $\begin{array}{r}\text { Raffinate/ } \\
\text { Residual }\end{array}$ \\
\hline $\mathrm{H}$ & & & $99.0 \%$ & \begin{tabular}{|l|}
$1.0 \%$ \\
\end{tabular} & & \\
\hline C & $16.0 \%$ & & & & $84.0 \%$ & \\
\hline Inert gases & & & $99.9 \%$ & $0.1 \%$ & & \\
\hline Se79 & $1.5 \%$ & & & & $98.5 \%$ & \\
\hline $\mathrm{Rb}$ & $0.1 \%$ & & & & & $99.9 \%$ \\
\hline $\mathrm{Sr}$ & $0.1 \%$ & & & & & $99.9 \%$ \\
\hline $\mathrm{Zr}$ & $1.0 \%$ & & & & $99.0 \%$ & \\
\hline Tc & $1.5 \%$ & & & & $98.5 \%$ & \\
\hline Ru106 & $1.5 \%$ & & & & $98.5 \%$ & \\
\hline Pd107 & $1.5 \%$ & & & & $98.5 \%$ & \\
\hline Mo-Ru-Rh-Pd & $1.5 \%$ & & & & $98.5 \%$ & \\
\hline Cd113m & $1.5 \%$ & & & & $98.5 \%$ & \\
\hline Sn126 & $1.5 \%$ & & & & $98.5 \%$ & \\
\hline Sb125 & $1.5 \%$ & & & & $98.5 \%$ & \\
\hline Transition metals & $1.5 \%$ & & & & $98.5 \%$ & \\
\hline Halogens & $0.1 \%$ & & & & & $99.90 \%$ \\
\hline Cs & $0.1 \%$ & & & & & $99.90 \%$ \\
\hline $\mathrm{Ba}$ & $0.1 \%$ & & & & & $99.90 \%$ \\
\hline Lanthanides & $0.1 \%$ & $5.0 \%$ & & & & $94.90 \%$ \\
\hline $\mathrm{Ac}, \mathrm{Th}, \mathrm{Pa}$ & & $99.2 \%$ & & & $0.7 \%$ & $0.10 \%$ \\
\hline U & $71.0 \%$ & $28.2 \%$ & & & $0.7 \%$ & $0.10 \%$ \\
\hline $\mathrm{Np}$ & & $99.2 \%$ & & & $0.7 \%$ & $0.10 \%$ \\
\hline $\mathrm{Pu}$ & & $99.2 \%$ & & & $0.7 \%$ & $0.10 \%$ \\
\hline $\mathrm{Am}, \mathrm{Cm}, \mathrm{Bk}, \mathrm{Cf}$ & & $99.2 \%$ & & & $0.7 \%$ & $0.10 \%$ \\
\hline
\end{tabular}


Table A4. FIT 2.0 Working-Value Separation Factors for Electrochemical Separation.

\begin{tabular}{|l|c|c|c|c|c|c|}
\hline & $\begin{array}{c}\text { Recovered } \\
\mathrm{U}\end{array}$ & $\begin{array}{c}\text { U-TRU } \\
\text { Product }\end{array}$ & $\begin{array}{c}\text { Captured } \\
\text { Gases }\end{array}$ & $\begin{array}{c}\text { Effluents } \\
\text { Released }\end{array}$ & $\begin{array}{c}\text { Cladding/ } \\
\text { coating }\end{array}$ & $\begin{array}{c}\text { Raffinate/ } \\
\text { Residual }\end{array}$ \\
\hline $\mathrm{H}$ & $16 \%$ & & $99.00 \%$ & $1.00 \%$ & & \\
\hline $\mathrm{C}$ & & & $99.9 \%$ & $0.1 \%$ & $84 \%$ & \\
\hline Inert gases & $1.5 \%$ & & & & $98.50 \%$ & \\
\hline $\mathrm{Se}$ & $0.1 \%$ & & & & & $99.9 \%$ \\
\hline $\mathrm{Rb}$ & $0.1 \%$ & & & & & $99.9 \%$ \\
\hline $\mathrm{Sr}$ & $1 \%$ & & & & $99 \%$ & \\
\hline $\mathrm{Zr}$ & $1.5 \%$ & & & & $98.50 \%$ & \\
\hline $\mathrm{Nb}$ & $1.5 \%$ & & & & $98.50 \%$ & \\
\hline $\mathrm{Mo}$ & $1.5 \%$ & & & & $98.50 \%$ & \\
\hline $\mathrm{Tc}$ & $1.5 \%$ & & & & $98.50 \%$ & \\
\hline $\mathrm{Ru}$ & $1.5 \%$ & & & & $98.50 \%$ & \\
\hline $\mathrm{Re}$ & $1.5 \%$ & & & & $98.50 \%$ & \\
\hline $\mathrm{Pd}$ & $1.5 \%$ & & & & $98.50 \%$ & \\
\hline $\mathrm{Ag}$ & $1.5 \%$ & & & & $98.50 \%$ & \\
\hline $\mathrm{Cd}$ & $1.5 \%$ & & & & $98.50 \%$ & \\
\hline $\mathrm{In}$ & $1.5 \%$ & & & & $98.50 \%$ & \\
\hline $\mathrm{Sn}$ & $1.5 \%$ & & & & $98.50 \%$ & \\
\hline $\mathrm{Sb}$ & $1.5 \%$ & & & & $98.50 \%$ & \\
\hline $\mathrm{Te}$ & $0.1 \%$ & & & & & $99.9 \%$ \\
\hline $\mathrm{Halogens}$ & $0.1 \%$ & & & & & $99.9 \%$ \\
\hline $\mathrm{Cs}$ & $0.1 \%$ & & & & & $99.9 \%$ \\
\hline $\mathrm{Ba}$ & $0.1 \%$ & $5.0 \%$ & & & & $94.9 \%$ \\
\hline $\mathrm{Y}, \mathrm{La}$ to Ho & $0.1 \%$ & $5.0 \%$ & & & & $94.9 \%$ \\
\hline $\mathrm{Er}$ to Yb & & $99.2 \%$ & & & $0.7 \%$ & $0.1 \%$ \\
\hline $\mathrm{Ac}$ & & $99.2 \%$ & & & $0.7 \%$ & $0.1 \%$ \\
\hline $\mathrm{Th}$ & & $99.2 \%$ & & & $0.7 \%$ & $0.1 \%$ \\
\hline $\mathrm{Pa}$ & & $99.2 \%$ & & & $0.7 \%$ & $0.1 \%$ \\
\hline $\mathrm{U}$ & & $99.2 \%$ & & & $0.7 \%$ & $0.1 \%$ \\
\hline $\mathrm{Np}$ & & & & $0.7 \%$ & $0.1 \%$ \\
\hline $\mathrm{Pu}$ & $\mathrm{Am}, \mathrm{Cm}, \mathrm{Bk}, \mathrm{Cf}$ & & & & & \\
\hline
\end{tabular}

\section{A.4 AIROX Separation Factors - FIT 2.0 Updates from FIT 1.0}

Tables A5 and A6 show the FIT 1 and FIT 2 separation factors for AIROX, respectively. The values are generally the same except for how groups of elements are handled. In FIT 1.0, the catch-all value for Mo$\mathrm{Ru}-\mathrm{Rh}-\mathrm{Pd}$ was $33 \%$ retention in the fuel, whereas FIT 2.0 reflects the individual values for Mo (0.1\%), $\mathrm{Ru}(78 \%), \operatorname{Re}(99.9 \%)$, and Pd (99.9\%). Similarly, the catch-all value for other transition metals was $50 \%$ retention in fuel, whereas FIT reflects individual elemental values, which range from the default lower and upper bounds of $0.1 \%$ to $99.9 \%$. 
Table A5. FIT 1.0 Working-Value Separation Factors for AIROX.

\begin{tabular}{|l|r|r|r|r|}
\hline & $\begin{array}{r}\text { U-TRU } \\
\text { Product }\end{array}$ & $\begin{array}{c}\text { Captured } \\
\text { Gases }\end{array}$ & $\begin{array}{r}\text { Effluents } \\
\text { Released }\end{array}$ & $\begin{array}{r}\text { Raffinate/ } \\
\text { Residual }\end{array}$ \\
\hline $\mathrm{H}$ & & $99.0 \%$ & $1.0 \%$ & \\
\hline Inert gases & & $90.0 \%$ & $10.0 \%$ & \\
\hline Se79 & $99.9 \%$ & & & $0.1 \%$ \\
\hline Rb & $0.1 \%$ & & & $99.9 \%$ \\
\hline Sr & $99.9 \%$ & & & $0.1 \%$ \\
\hline Zr & $99.9 \%$ & & & $0.1 \%$ \\
\hline Tc & $0.1 \%$ & & & $99.9 \%$ \\
\hline Ru106 & $78.0 \%$ & & & $22.0 \%$ \\
\hline Pd107 & $99.9 \%$ & & & $0.1 \%$ \\
\hline Mo-Ru-Rh-Pd & $33.0 \%$ & & & $67.0 \%$ \\
\hline Cd113m & $0.1 \%$ & & & $99.9 \%$ \\
\hline Sn126 & $0.1 \%$ & & & $99.9 \%$ \\
\hline Sb125 & $99.9 \%$ & & & $0.1 \%$ \\
\hline Transition metals & $50.0 \%$ & & & $50.0 \%$ \\
\hline Halogens & & $99.90 \%$ & $0.05 \%$ & $0.05 \%$ \\
\hline Cs & $0.1 \%$ & & & $99.9 \%$ \\
\hline Ba & $99.9 \%$ & & & $0.1 \%$ \\
\hline Lanthanides & $99.9 \%$ & & & $0.1 \%$ \\
\hline Ac, Th, Pa & $99.9 \%$ & & & $0.1 \%$ \\
\hline U & $99.9 \%$ & & & $0.1 \%$ \\
\hline Np & $99.9 \%$ & & & $0.1 \%$ \\
\hline Pu & $99.9 \%$ & & & $0.1 \%$ \\
\hline Am, Cm, Bk, Cf & $99.9 \%$ & & & $0.1 \%$ \\
\hline
\end{tabular}


Table A6. FIT 2.0 Working-Value Separation Factors for AIROX.

\begin{tabular}{|l|c|c|c|c|}
\hline & $\begin{array}{c}\text { U-TRU } \\
\text { Product }\end{array}$ & $\begin{array}{c}\text { Captured } \\
\text { Gases }\end{array}$ & $\begin{array}{c}\text { Effluents } \\
\text { Released }\end{array}$ & $\begin{array}{c}\text { Raffinate/ } \\
\text { Residual }\end{array}$ \\
\hline $\mathrm{H}$ & $0.10 \%$ & $99.00 \%$ & $1.00 \%$ & \\
\hline $\mathrm{C}$ & & $99.90 \%$ & $10.00 \%$ & \\
\hline Inert gases & $50 \%$ & & $1 \%$ & \\
\hline $\mathrm{Se}$ & $0.1 \%$ & & & $50 \%$ \\
\hline $\mathrm{Rb}$ & $99.9 \%$ & & & $99.9 \%$ \\
\hline $\mathrm{Sr}$ & $99.90 \%$ & & & $0.1 \%$ \\
\hline $\mathrm{Zr}$ & $50 \%$ & & & $0.10 \%$ \\
\hline $\mathrm{Nb}$ & $0.10 \%$ & & & $50 \%$ \\
\hline $\mathrm{Mo}$ & $0.10 \%$ & & & $99.90 \%$ \\
\hline $\mathrm{Tc}$ & $78.0 \%$ & & & $22.90 \%$ \\
\hline $\mathrm{Ru}$ & $99.9 \%$ & & & $0.1 \%$ \\
\hline $\mathrm{Re}$ & $99.9 \%$ & & & $0.1 \%$ \\
\hline $\mathrm{Pd}$ & $80.0 \%$ & & & $20.0 \%$ \\
\hline $\mathrm{Ag}$ & $0.10 \%$ & & & $99.90 \%$ \\
\hline $\mathrm{Cd}$ & $0.10 \%$ & & & $99.90 \%$ \\
\hline $\mathrm{In}$ & $0.10 \%$ & & & $99.90 \%$ \\
\hline $\mathrm{Sn}$ & $99.90 \%$ & & & $0.10 \%$ \\
\hline $\mathrm{Sb}$ & $50 \%$ & & & $50 \%$ \\
\hline $\mathrm{Te}$ & & $99.90 \%$ & $0.05 \%$ & $0.05 \%$ \\
\hline $\mathrm{Halogens}$ & $0.1 \%$ & & & $99.9 \%$ \\
\hline $\mathrm{Cs}$ & $99.9 \%$ & & & $0.1 \%$ \\
\hline $\mathrm{Ba}$ & $99.9 \%$ & & & $0.1 \%$ \\
\hline $\mathrm{Y}, \mathrm{La}$ to Ho & $99.9 \%$ & & & $0.1 \%$ \\
\hline $\mathrm{Er}$ to $\mathrm{Yb}$ & $99.9 \%$ & & & $0.1 \%$ \\
\hline $\mathrm{Ac}$ & $99.9 \%$ & & & $0.1 \%$ \\
\hline $\mathrm{Th}$ & $99.9 \%$ & & & $0.1 \%$ \\
\hline $\mathrm{Pa}$ & $99.9 \%$ & & & $0.1 \%$ \\
\hline $\mathrm{U}$ & $99.9 \%$ & & & $0.1 \%$ \\
\hline $\mathrm{Np}$ & $99.9 \%$ & & & $0.1 \%$ \\
\hline $\mathrm{Pu}$ & $99.9 \%$ & & & $0.1 \%$ \\
\hline $\mathrm{Am}, \mathrm{Cm}, \mathrm{Bk}, \mathrm{Cf}$ & & & & \\
\hline
\end{tabular}

\section{A.5 Melt Refining Separation Factors - FIT 2.0 Updates from FIT 1.0}

Tables A7 and A8 show the FIT 1 and FIT 2 separation factors for melt refining, respectively. The values are the same except for how groups of elements are handled. In FIT 1, Cd113m was assigned 0.1\% retention in the TRU-U product, but all the other transition metals were assigned $92 \%$, including other $\mathrm{Cd}$ isotopes. In FIT 2, all the $\mathrm{Cd}$ isotopes (not just $\mathrm{Cd} 113 \mathrm{~m}$ ) are assigned 0.1. 
Table A7. FIT 1.0 Working-Value Separation Factors for Melt Refining.

\begin{tabular}{|l|r|r|r|r|}
\hline & $\begin{array}{r}\text { U-TRU } \\
\text { Product }\end{array}$ & $\begin{array}{c}\text { Captured } \\
\text { Gases }\end{array}$ & $\begin{array}{c}\text { Effluents } \\
\text { Released }\end{array}$ & $\begin{array}{r}\text { Raffinate/ } \\
\text { Residual }\end{array}$ \\
\hline $\mathrm{H}$ & & $99.0 \%$ & $1.0 \%$ & \\
\hline Inert gases & & $90.0 \%$ & $10.0 \%$ & \\
\hline Se79 & $92.0 \%$ & & & $8.0 \%$ \\
\hline Rb & $0.1 \%$ & & & $99.9 \%$ \\
\hline Sr & $5.0 \%$ & & & $95.0 \%$ \\
\hline Zr & $92.0 \%$ & & & $8.0 \%$ \\
\hline Tc & $92.0 \%$ & & & $8.0 \%$ \\
\hline Ru106 & $92.0 \%$ & & & $8.0 \%$ \\
\hline Pd107 & $92.0 \%$ & & & $8.0 \%$ \\
\hline Mo-Ru-Rh-Pd & $92.0 \%$ & & & $8.0 \%$ \\
\hline Cd113m & $0.1 \%$ & & & $99.9 \%$ \\
\hline Sn126 & $92.0 \%$ & & & $8.0 \%$ \\
\hline Sb125 & $92.0 \%$ & & & $8.0 \%$ \\
\hline Transition metals & $92.0 \%$ & & & $8.0 \%$ \\
\hline Halogens & & $99.90 \%$ & $0.05 \%$ & $0.05 \%$ \\
\hline Cs & $0.1 \%$ & & & $99.9 \%$ \\
\hline Ba & $9.1 \%$ & & & $99.9 \%$ \\
\hline Lanthanides & $1.0 \%$ & & & $99.0 \%$ \\
\hline Ac, Th, Pa & $99.9 \%$ & & & $0.1 \%$ \\
\hline U & $92.0 \%$ & & & $8.0 \%$ \\
\hline Np & $92.0 \%$ & & & $8.0 \%$ \\
\hline Pu & $92.0 \%$ & & & $8.0 \%$ \\
\hline Am, Cm, Bk, Cf & & & $8.0 \%$ \\
\hline
\end{tabular}


Table A8. FIT 2.0 Working-Value Separation Factors for Melt Refining.

\begin{tabular}{|l|c|c|c|c|}
\hline & $\begin{array}{c}\text { U-TRU } \\
\text { Product }\end{array}$ & $\begin{array}{c}\text { Captured } \\
\text { Gases }\end{array}$ & $\begin{array}{c}\text { Effluents } \\
\text { Released }\end{array}$ & $\begin{array}{c}\text { Raffinate/ } \\
\text { Residual }\end{array}$ \\
\hline $\mathrm{H}$ & & $99.0 \%$ & $1.0 \%$ & \\
\hline $\mathrm{C}$ & $0.1 \%$ & $89.9 \%$ & $10.0 \%$ & \\
\hline Inert gases & & $99.0 \%$ & $1.0 \%$ & \\
\hline $\mathrm{Se}$ & $92.0 \%$ & & & $8.0 \%$ \\
\hline $\mathrm{Rb}$ & $0.1 \%$ & & & $99.9 \%$ \\
\hline $\mathrm{Sr}$ & $5.0 \%$ & & & $95.0 \%$ \\
\hline $\mathrm{Zr}$ & $92.0 \%$ & & & $8.0 \%$ \\
\hline $\mathrm{Nb}$ & $92.0 \%$ & & & $8.0 \%$ \\
\hline $\mathrm{Mo}$ & $92.0 \%$ & & & $8.0 \%$ \\
\hline $\mathrm{Tc}$ & $92.0 \%$ & & & $8.0 \%$ \\
\hline $\mathrm{Ru}$ & $92.0 \%$ & & & $8.0 \%$ \\
\hline $\mathrm{Re}$ & $92.0 \%$ & & & $8.0 \%$ \\
\hline $\mathrm{Pd}$ & $92.0 \%$ & & & $8.0 \%$ \\
\hline $\mathrm{Ag}$ & $92.0 \%$ & & & $8.0 \%$ \\
\hline $\mathrm{Cd}$ & $0.1 \%$ & & & $99.9 \%$ \\
\hline $\mathrm{In}$ & $92.0 \%$ & & & $8.0 \%$ \\
\hline $\mathrm{Sn}$ & $92.0 \%$ & & & $8.0 \%$ \\
\hline $\mathrm{Sb}$ & $92.0 \%$ & & & $8.0 \%$ \\
\hline $\mathrm{Te}$ & $92.0 \%$ & & & $8.0 \%$ \\
\hline $\mathrm{Halogens}$ & & $99.90 \%$ & $0.05 \%$ & $0.05 \%$ \\
\hline $\mathrm{Cs}$ & $0.1 \%$ & & & $99.9 \%$ \\
\hline $\mathrm{Ba}$ & $0.1 \%$ & & & $99.9 \%$ \\
\hline $\mathrm{Y}, \mathrm{La} \mathrm{to} \mathrm{Ho}$ & $1.0 \%$ & & & $99.0 \%$ \\
\hline $\mathrm{Er}$ to $\mathrm{Yb}$ & $1.0 \%$ & & & $99.0 \%$ \\
\hline $\mathrm{Ac}$ & $99.9 \%$ & & & $0.1 \%$ \\
\hline $\mathrm{Th}$ & $95.0 \%$ & & & $5.0 \%$ \\
\hline $\mathrm{Pa}$ & $99.9 \%$ & & & $0.1 \%$ \\
\hline $\mathrm{U}$ & $92.0 \%$ & & & $8.0 \%$ \\
\hline $\mathrm{Np}$ & $92.0 \%$ & & & $8.0 \%$ \\
\hline $\mathrm{Pu}$ & $92.0 \%$ & & & $8.0 \%$ \\
\hline $\mathrm{Am}, \mathrm{Cm}, \mathrm{Bk}, \mathrm{Cf}$ & $92.0 \%$ & & & $8.0 \%$ \\
\hline
\end{tabular}




\section{A.6 PUREX Separation Factors (New)}

Table A9. FIT 2.0 Working-Value Separation Factors for PUREX.

\begin{tabular}{|c|c|c|c|c|c|c|c|}
\hline & \begin{tabular}{|c|} 
Recovered \\
$U$
\end{tabular} & $\begin{array}{l}\text { U-TRU } \\
\text { Product }\end{array}$ & \begin{tabular}{|c|}
$\begin{array}{c}\text { Captured } \\
\text { Gases }\end{array}$ \\
\end{tabular} & \begin{tabular}{|l|} 
Effluents \\
Released
\end{tabular} & $\begin{array}{c}\text { Cladding/ } \\
\text { Coating } \\
\end{array}$ & UDS & \begin{tabular}{|l|} 
Raffinate/ \\
Residual \\
\end{tabular} \\
\hline Hydrogen $(\mathrm{H})$ & & & $99 \%$ & $1 \%$ & & & \\
\hline Helium $(\mathrm{He})$ & & & & $100 \%$ & & & \\
\hline Lithium (Li) & $0.099 \%$ & & & & $0.1 \%$ & $1 \%$ & $98.801 \%$ \\
\hline Beryllium $(\mathrm{Be})$ & $0.396 \%$ & & & & $0.1 \%$ & $1 \%$ & $98.504 \%$ \\
\hline Boron (B) & & & & & & $1 \%$ & $99 \%$ \\
\hline Carbon $(C)$ & & & $90 \%$ & $10 \%$ & & & \\
\hline Nitrogen $(\mathrm{N})$ & & & & & & $1 \%$ & $99 \%$ \\
\hline Oxygen (O) & & & & & & $1 \%$ & $99 \%$ \\
\hline Flourine (F) & & & & & & $1 \%$ & $99 \%$ \\
\hline Neon $(\mathrm{Ne})$ & & & $99 \%$ & $1 \%$ & & & \\
\hline Sodium $(\mathrm{Na})$ & $0.0990 \%$ & & & & $0.1 \%$ & $1 \%$ & $98.801 \%$ \\
\hline Magnesium (Mg) & $0.3960 \%$ & & & & $0.1 \%$ & $1 \%$ & $98.504 \%$ \\
\hline Aluminum (Al) & & & & & & $1 \%$ & $99 \%$ \\
\hline Silicon (Si) & & & & & & $1 \%$ & $99 \%$ \\
\hline$P, S$ & & & & & & $1 \%$ & $99 \%$ \\
\hline Chlorine $(\mathrm{Cl})$ & & & & & & $1 \%$ & $99 \%$ \\
\hline Argon (Ar) & & & $99 \%$ & $1 \%$ & & & \\
\hline Potassium (K) & $0.099 \%$ & & & & $0.1 \%$ & $1 \%$ & $98.801 \%$ \\
\hline Calcium (Ca) & $0.396 \%$ & & & & $0.1 \%$ & $1 \%$ & $98.504 \%$ \\
\hline $\mathrm{Sc}, \mathrm{Ti}, \mathrm{V}, \mathrm{Cr}, \mathrm{Mn}, \mathrm{Fe}$ & & & & & & $1 \%$ & $99 \%$ \\
\hline $\mathrm{Co}, \mathrm{Ni}, \mathrm{Cu}, \mathrm{Zn}$ & $0.0990 \%$ & & & & $0.1 \%$ & $1 \%$ & $98.8010 \%$ \\
\hline Gallium (Ga) & $0.0990 \%$ & & & & $0.1 \%$ & $1 \%$ & $98.8010 \%$ \\
\hline Ge, As & $0.0990 \%$ & & & & $0.1 \%$ & $1 \%$ & $98.8010 \%$ \\
\hline \begin{tabular}{|l} 
Selenium (Se) \\
\end{tabular} & $0.0990 \%$ & & & & $0.1 \%$ & $1 \%$ & $98.8010 \%$ \\
\hline Bromine $(\mathrm{Br})$ & & & $99.999 \%$ & $0.001 \%$ & & & \\
\hline Krypton (Kr) & & & $99 \%$ & $1 \%$ & & & \\
\hline Rubidium (Rb) & $0.0990 \%$ & & & & $0.1 \%$ & $1 \%$ & $98.8010 \%$ \\
\hline Strontium $(\mathrm{Sr})$ & $0.3960 \%$ & & & & $0.1 \%$ & $1 \%$ & $98.5040 \%$ \\
\hline Yttrium $(\mathrm{Y})$ & $0.0990 \%$ & $0.0979 \%$ & & & $0.1 \%$ & $1 \%$ & $98.7031 \%$ \\
\hline Zirconium (Zr) & $0.3960 \%$ & & & & $0.1 \%$ & $1 \%$ & $98.5040 \%$ \\
\hline Niobium $(\mathrm{Nb})$ & $0.0990 \%$ & & & & $0.1 \%$ & $1 \%$ & $98.8010 \%$ \\
\hline Molybdenum (Mo) & $1.5840 \%$ & & & & $0.1 \%$ & $1 \%$ & $97.3160 \%$ \\
\hline Technetium (Tc) & $0.1000 \%$ & & & & $0.1 \%$ & $1 \%$ & $98.8000 \%$ \\
\hline Ruthenium (Ru) & $2.0790 \%$ & & & & $0.1 \%$ & $1 \%$ & $96.8210 \%$ \\
\hline Rhenium $(\operatorname{Re})$ & $1.5840 \%$ & & & & $0.1 \%$ & $1 \%$ & $97.3160 \%$ \\
\hline Palladium $(\mathrm{Pd})$ & $5.3460 \%$ & & & & $0.1 \%$ & $1 \%$ & $93.5540 \%$ \\
\hline Silver $(\mathrm{Ag})$ & $0.0990 \%$ & & & & $0.1 \%$ & $1 \%$ & $98.8010 \%$ \\
\hline Cadmium (Cd) & $0.0990 \%$ & & & & $0.1 \%$ & $1 \%$ & $98.8010 \%$ \\
\hline Indium (In) & $0.0990 \%$ & & & & $0.1 \%$ & $1 \%$ & $98.8010 \%$ \\
\hline Tin (Sn) & $45.4410 \%$ & & & & $0.1 \%$ & $1 \%$ & $53.4590 \%$ \\
\hline Antimony (Sb) & $7.6230 \%$ & & & & $0.1 \%$ & $1 \%$ & $91.2770 \%$ \\
\hline Tellurium (Te) & $0.0990 \%$ & & & & $0.1 \%$ & $1 \%$ & $98.8010 \%$ \\
\hline lodine (I) & & & $99.999 \%$ & $0.001 \%$ & & & \\
\hline Xenon (Xe) & & & $99 \%$ & $1 \%$ & & & \\
\hline Cesium (Cs) & $0.3960 \%$ & & & & $0.1 \%$ & $1 \%$ & $98.5040 \%$ \\
\hline Barium (Ba) & $0.0495 \%$ & & & & $0.1 \%$ & $1 \%$ & $98.8505 \%$ \\
\hline Lanthanides & $0.0990 \%$ & & & & $0.1 \%$ & $1 \%$ & $98.8010 \%$ \\
\hline Hafnium (Hf) & $0.3960 \%$ & & & & & $1 \%$ & $98.6040 \%$ \\
\hline Tantalum (Ta) & $2.3760 \%$ & & & & & $1 \%$ & $96.6240 \%$ \\
\hline Tungsten (W) & $2.3760 \%$ & & & & & $1 \%$ & $96.6240 \%$ \\
\hline Rhenium $(\mathrm{Re})$ & $94.5450 \%$ & & & & & $1 \%$ & $4.4550 \%$ \\
\hline Osmium (Os) & $2.0790 \%$ & & & & & $1 \%$ & $96.9210 \%$ \\
\hline Iridium (Ir) & $0.2970 \%$ & & & & & $1 \%$ & $98.7030 \%$ \\
\hline Platinum (Pt) & $5.3460 \%$ & & & & & $1 \%$ & $93.6540 \%$ \\
\hline Gold (Au) & $2.1780 \%$ & & & & & $1 \%$ & $96.8220 \%$ \\
\hline Mercury $(\mathrm{Hg})$ & $0.0990 \%$ & & & & & $1 \%$ & $98.9010 \%$ \\
\hline Thallium (TI) & $0.1386 \%$ & & & & & $1 \%$ & $98.8614 \%$ \\
\hline $\mathrm{Pb}, \mathrm{Bi}$ & $0.0990 \%$ & $0.1 \%$ & & & $0.1 \%$ & $1 \%$ & $98.7010 \%$ \\
\hline Radium (Ra) & $0.0495 \%$ & $0.1 \%$ & & & $0.1 \%$ & $1 \%$ & $98.7505 \%$ \\
\hline $\mathrm{Ac}, \mathrm{Th}, \mathrm{Pa}$ & $0.0792 \%$ & $0.1 \%$ & & & $0.1 \%$ & $1 \%$ & $98.7208 \%$ \\
\hline Uranium (U) & $98.9970 \%$ & $0.1 \%$ & & & $0.1 \%$ & & $0.8030 \%$ \\
\hline Neptunium (Np) & $1.7820 \%$ & $0.1 \%$ & & & $0.1 \%$ & & $98.0180 \%$ \\
\hline Plutonium (Pu) & $0.0003 \%$ & $98.96 \%$ & & & $0.1 \%$ & & $0.9366 \%$ \\
\hline $\mathrm{Am}, \mathrm{Cm}, \mathrm{Bk}, \mathrm{Cf}$ & $0.0792 \%$ & $0.1 \%$ & & & $0.1 \%$ & $1 \%$ & $98.7208 \%$ \\
\hline
\end{tabular}


Appendix B

Illustrative Impurity Accumulation Calculations using UREX+1, Electrochemical, AIROX, and Melt Refining 
This page intentionally left blank. 


\section{B.1 Cases Ran}

This appendix updates the FY10 cases in the Losses study with the new model and separation factors. All cases (Table B1) used the following:

- $\quad$ Incoming fuel $=$ LWR-UOX-51

- $\quad$ Fast reactor with TRU conversion ratio of 0.5

- Compositions allowed to go above working Fuel Campaign impurity limits, constrained only by physics, i.e., whether it is possible to adjust the TRU/U ratio sufficient to keep k-infinity the same value as the impurity-free original fuel recipe.

Table B1. Cases Analyzed with FIT 2.0.

\begin{tabular}{|c|c|c|c|c|c|c|c|}
\hline Case & $\begin{array}{c}\text { Separation } \\
1\end{array}$ & $\begin{array}{c}\text { Recycle } \\
\text { Fuel }\end{array}$ & $\begin{array}{c}\text { Separation } \\
2\end{array}$ & Uranium & $\begin{array}{l}\text { FIT } 1.0 \\
\text { behavior }\end{array}$ & $\begin{array}{l}\text { FIT } 2.0 \\
\text { behavior } \\
\text { with old sep } \\
\text { factors }\end{array}$ & $\begin{array}{l}\text { FIT } 2.0 \\
\text { behavior } \\
\text { with new } \\
\text { sep factors }\end{array}$ \\
\hline 1 & UREX+1 & Metal & Electrochemical & RU-1/RU-2 & \multicolumn{3}{|c|}{ Physics allows continuous recycle } \\
\hline 2 & UREX+1 & Metal & Electrochemical & DU $/ \mathrm{DU}$ & \multicolumn{3}{|c|}{ Physics allows continuous recycle } \\
\hline 3 & UREX+1 & Metal & Melt refining & RU-1/DU & $\begin{array}{l}\text { Physics } \\
\text { allows } \\
3 \text { recycles } \\
\end{array}$ & $\begin{array}{c}\text { Physics } \\
\text { allows } \\
4 \text { recycles } \\
\end{array}$ & $\begin{array}{l}\text { Physics } \\
\text { allows } \\
3 \text { recycles }\end{array}$ \\
\hline 4 & $\begin{array}{l}\text { Melt } \\
\text { refining }\end{array}$ & Metal & & & \multicolumn{3}{|c|}{$\begin{array}{l}\text { Even a single recycle is impossible. } \\
\text { Melt refining does not allow adjustment } \\
\text { of the TRU/U ratio, thus making FR fuel } \\
\text { from used LWR UOX is impossible. }\end{array}$} \\
\hline 5 & UREX+1 & Oxide & UREX+1 & RU-1/RU-2 & \multicolumn{3}{|c|}{ Physics allows continuous recycle } \\
\hline 6 & $\mathrm{UREX}+1$ & Oxide & $\mathrm{UREX}+1$ & $\mathrm{DU} / \mathrm{DU}$ & \multicolumn{3}{|c|}{ Physics allows continuous recycle } \\
\hline 7 & $\mathrm{UREX}+1$ & Oxide & AIROX & RU-1/DU & $\begin{array}{l}\text { Physics } \\
\text { allows } \\
3 \text { recycles }\end{array}$ & $\begin{array}{c}\text { Physics } \\
\text { allows } \\
4 \text { recycles }\end{array}$ & $\begin{array}{l}\text { Physics } \\
\text { allows } \\
3 \text { recycles }\end{array}$ \\
\hline 8 & AIROX & Oxide & & & \multicolumn{3}{|c|}{$\begin{array}{l}\text { Even a single recycle is impossible. } \\
\text { AIROX does not allow adjustment of the } \\
\text { TRU/U ratio, thus making FR fuel from } \\
\text { used LWR UOX is impossible. }\end{array}$} \\
\hline
\end{tabular}

As another example, consider the possible use of electrochemical to make used fuel. For the FR case noted above, the input fuel is $30 \%$ TRU and $70 \% \mathrm{U}$.

When simply recycling used FR fuel, there is no problem. The nominal retention factors in the TRU+U main product for $99 \% \mathrm{TRU}, 28 \% \mathrm{U}$, and $1 \%$ fission products. The output fuel (if metal) is $24 \% \mathrm{TRU}$, $62 \%$ TRU, and $14 \%$ fission products. Therefore, the TRU+U stream is given by

TRU $24 \% \times 99 \%=24 \%$ of original stream

U $\quad 62 \% \times 28 \%=17 \%$ of original stream

FP $14 \% \times \quad 1 \%=0.1 \%$ of original stream

So, the TRU+U product is $59 \%$ TRU and $41 \%$. Simple dilution with uranium can get it back to the $30 \%$ TRU/70\% U input composition.

Now, consider what happens when if one tries to use electrochemical on used LWR-UOX. The output fuel is $1.3 \%$ TRU, $93 \% \mathrm{U}$, and $4.3 \%$ fission products. Therefore, the TRU+U stream is given by 
TRU $1.3 \%$ x $99 \%=1.3 \%$ of original stream

U $\quad 93 \% \times 28 \%=26 \%$ of original stream

FP $\quad 4.3 \% \times 1 \%=0.1 \%$ of original stream

So, the TRU+U product is 5\% TRU and 95\% U. Of course, uranium dilution cannot be used to get this to a fuel product that is $30 \%$ TRU and $70 \% \mathrm{U}$. That is, electrochemical separation that keeps $28 \%$ of the input uranium with TRU cannot be used to make electrochemical fuel from LWR-UOX. To use electrochemical with used LWR-UOX to make $30 \% / 70 \% \mathrm{CR}=0.5$ fast reactor fuel, the upper bound of uranium that can be retained with TRU is 3.3\%. Otherwise, FIT will immediately tell the user that it cannot adjust the TRU:U blending to make the fuel.

This is also why melt refining (case 4) and AIROX (case 8) cannot be used to make fast reactor fuel from used LWR-UOX.

\section{B.2 Results}

Here, we update the results originally provided in chapter 4 of the 2010 losses study report.[Piet2010b]

For oxide fuels, the broad results are similar to FIT with a few key transition metals apparently accumulating to higher impurity levels than predicted by FIT 1.

AIROX cannot be used to process LWR-UOX fuel to make fast reactor fuel. If UREX+1 is used to process LWR-UOX fuel, but AIROX used on used fast reactor fuel, 3 recycles are theoretically possible from the physics standpoint. The first recycle is solely UREX +1 fed because there is no used FR fuel yet. But, the second recycle in the AIROX case (the first in which AIROX is itself used), several impurity limits are exceeded, e.g., lanthanides. Thus, in short, AIROX does not work for this application.

When UREX +1 is used to process both LWR-UOX and fast reactor fuel, we have the following results:

- 2009 working limits met - lanthanides, group 1 (alkali metals), group 2 (alkaline earths)

- 2009 working limits not met $-\mathrm{Mo}+\mathrm{Ag}, \mathrm{Ru}, \mathrm{Cd}+\mathrm{Sn}-$ these are 2-4x times higher with FIT 2 than FIT 1 because of element-specific treatment.

- Elements not covered by 2009 working limits but predicted to accumulate $>100 \mathrm{ppm}-\mathrm{Zr}$, Tc, $\mathrm{Pd}$, and Te. The Pd results are higher; the Te results are lower than FIT 1.

For metal fuels, the broad results are similar to FIT with a few key transition metals accumulating to different than predicted by FIT 1.

Melt refining cannot be used to process LWR-UOX fuel to make fast reactor fuel. If UREX+1 is used to process LWR-UOX fuel, but melt refining used on used fast reactor fuel, 3 recycles are theoretically possible from the physics standpoint (the first recycle is solely UREX +1 fed because there is no used FR fuel yet). But, the second recycle in the melt refining case (the first in which AIROX is itself used), several impurity limits are exceeded. Thus, in short, melt refining does not work for this application.

When UREX +1 is used to process LWR-UOX and electrochemical is used on fast reactor fuel, we have the following results:

- 2009 working limits met - cadmium

- 2009 working limits not met - lanthanides and molybdenum.

- Elements not covered by 2009 working limits but predicted to accumulate $>100 \mathrm{ppm}$ - group2 (alkaline earths), Tc, Ru, Rh, Pd, and Sn. The Pd results are higher; the Te results are lower than FIT 1. 


\section{B.2.1 Oxide fuel with AIROX}

If AIROX is used on used LWR-UOX (case 8), fast reactor fuel cannot be made and FIT stops immediately.

If UREX +1 is used on used LWR-UOX and AIROX is used on fast reactor fuel (case 7), 3 recycles are possible from the physics standpoint. Figure B1 shows the actinide and total impurities for the oxide fuel case in which AIROX is used to recycled used FR fuel. Recycle 1 has low impurities since it uses only feed from UREX+1 separation of used UOX-51 fuel. Thereafter the impurities increase substantially as FIT blends used UOX-51 (from UREX+1) with used FR fuel that has been separated with AIROX. The model cannot proceed past 3 recycles because the impurities become too high (FIT2=16\%, FIT1=13\%) to maintain criticality, even with no uranium dilution from $\mathrm{UREX}+1$, i.e., the model attempts to make recycle-4 using only TRU from UREX +1 treatment of UOX-51 plus AIROX feed from treatment of used FR fuel.

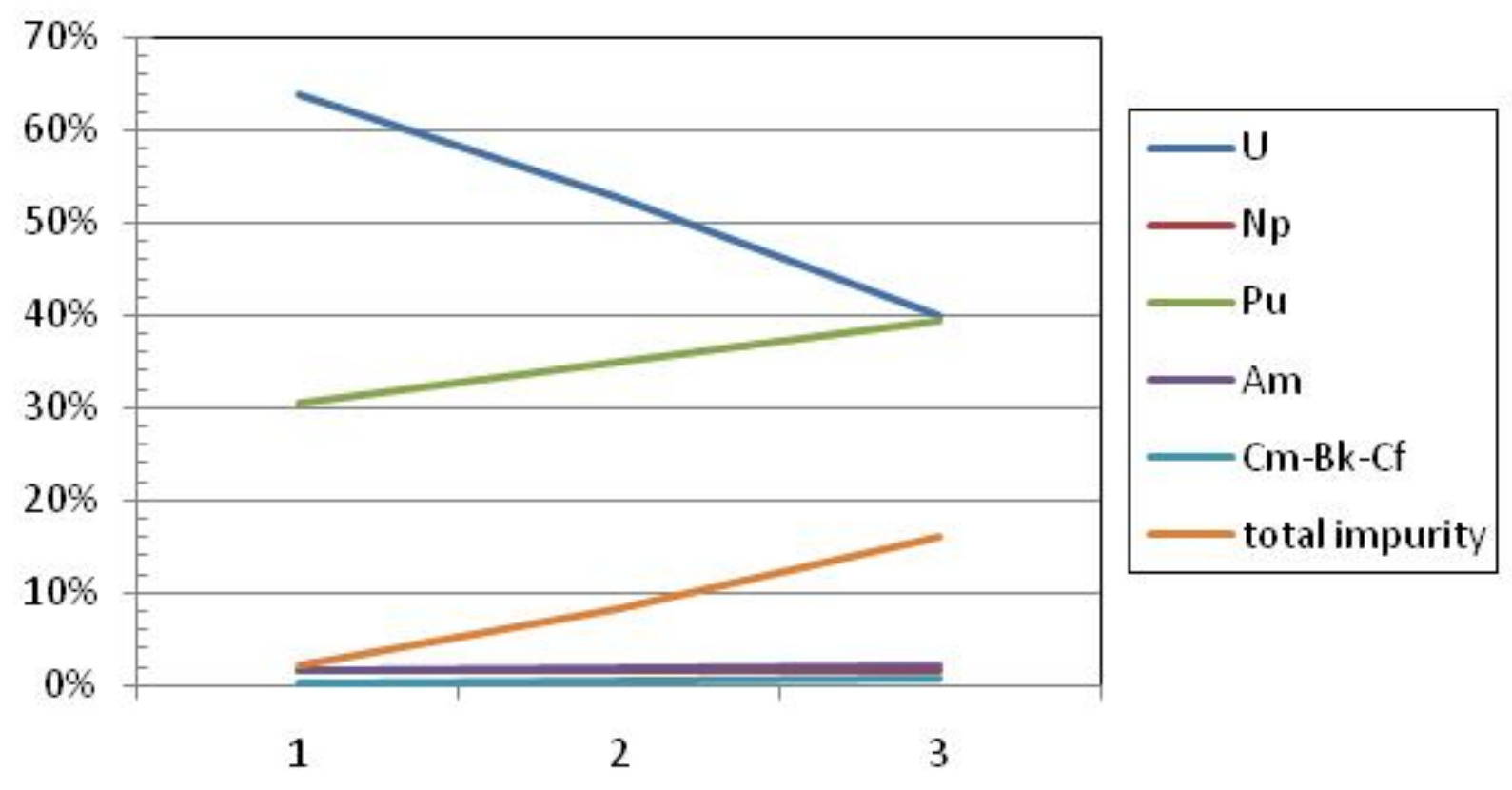

\section{Recycle number}

Figure B1. Composition for fast reactor oxide fuel: UREX+1 on LWR-UOX fuel and AIROX on FR fuel.

\section{B.2.2 Oxide fuel with UREX+1 of fast reactor fuel}

This subsection has UREX+1 separation on both used LWR-UOX and used fast reactor fuel. The source of uranium for dilution is either RU-1/RU-2 (case 5) or DU (case 6). Only when recovered uranium has significant impurities relative to the impurities that come with TRU do the RU versus DU results differ significantly. Of course, the estimated impurities with RU are always higher than DU feed; DU is assumed chemically pure.

Figures B2 and B3 show the actinide and total impurity content for RU (case 5) and DU (case 6). The behaviors are almost identical. 


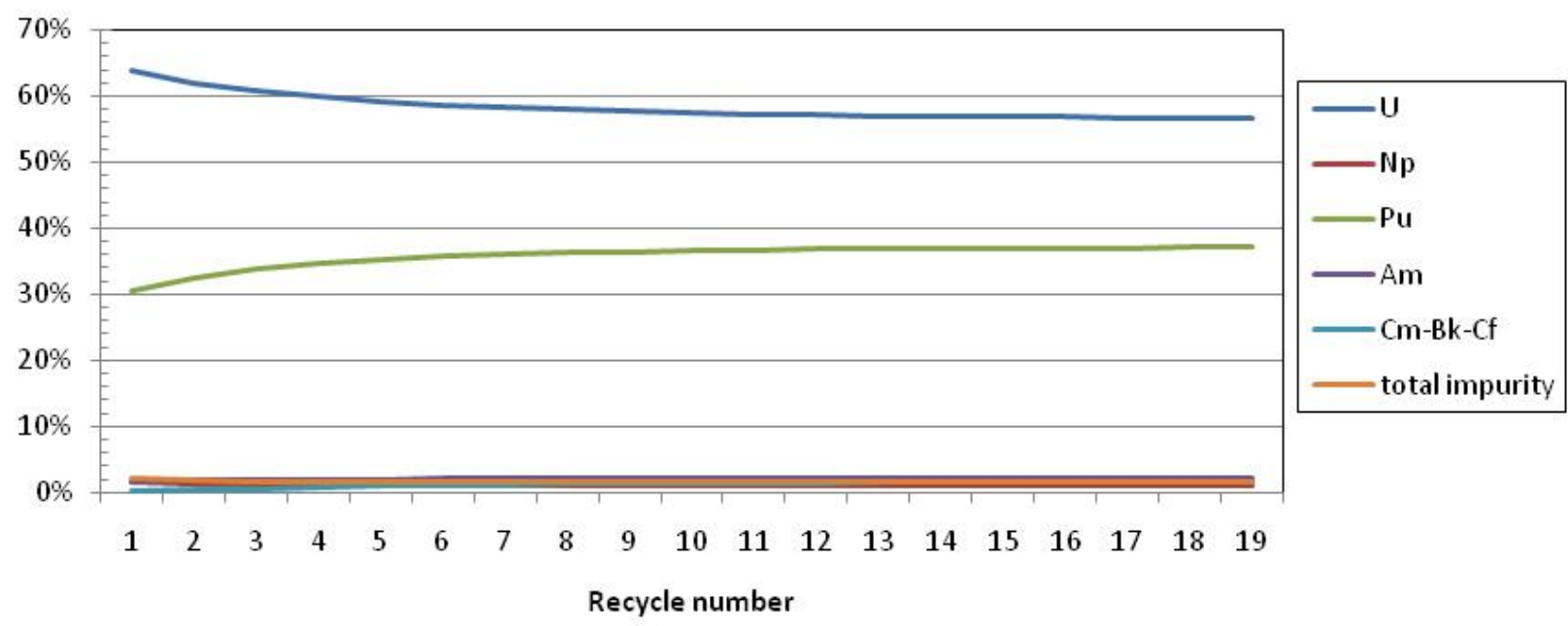

Figure B2. Composition for fast reactor oxide fuel: UREX+1 on LWR-UOX and FR fuel, RU feed.

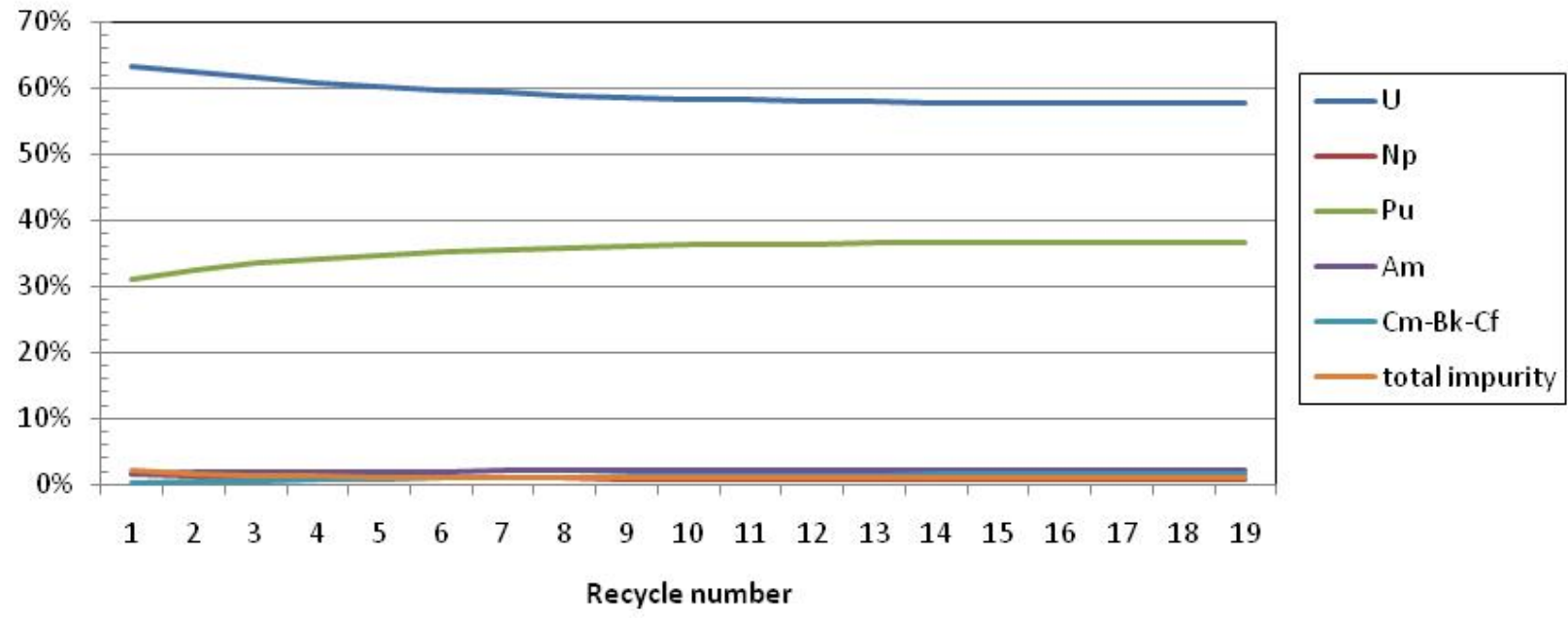

Figure B3. Composition for fast reactor oxide fuel: UREX+1 on LWR-UOX and FR fuel, DU feed.

\section{Lanthanides - within limits}

The 2009 working limits from the Fuels Campaign in these units are

$660 \mathrm{ppm}$ - Elements form oxide hydrates and oxides that make control of O:M ratio difficult in pellet sintering. This limit is for $\mathrm{La}, \mathrm{Ce}, \mathrm{Pr}$, and $\mathrm{Nd}$.

$132 \mathrm{ppm}$ - Restricted as thermal neutron resonance absorbers (poisons) This limit is for $\mathrm{Sm}, \mathrm{Eu}, \mathrm{Gd}$, $\mathrm{Tb}$, and $\mathrm{Dy}$.

Although the FIT 2 estimates (figure B4) are triple those from FIT 1 because the separation factor is triple, they are still below the working limits for the UREX +1 cases (with either RU or DU feed). Since the lanthanides are not volatile, they quickly exceed limits when AIROX is used for FR fuel and thus the AIROX curve in the figure goes off scale after recycle 1. 


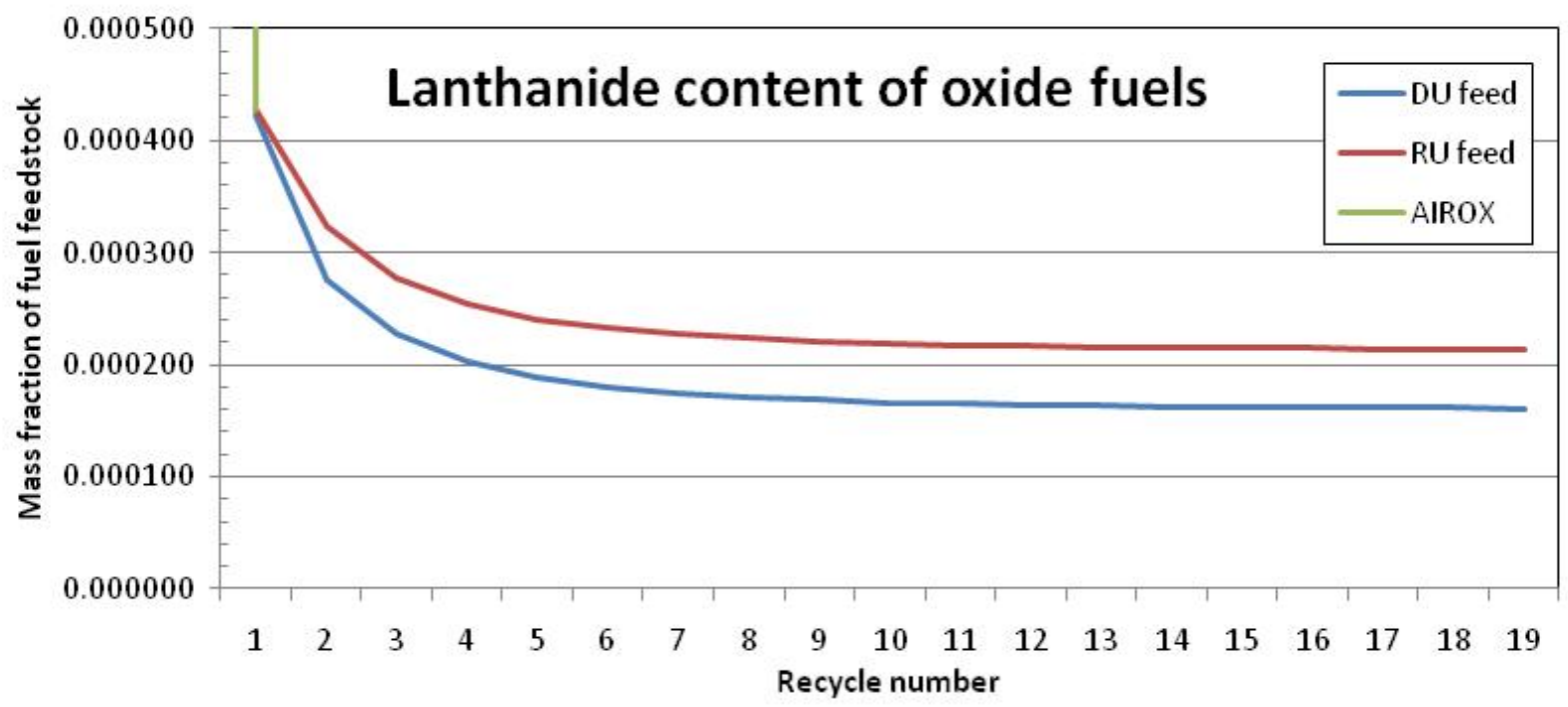

Figure B4. Lanthanide content for fast reactor oxide fuel, UREX +1 is always used on used LWR-UOX.

\section{Group 1 alkali metals $(\mathrm{Rb}, \mathrm{Cs})$ - within presumed limits}

The 2009 working limit from the Fuels Campaign is 462 ppm because "reactive metals that form compounds oxides which can melt or decompose at temperatures below the fuel sintering temperature causing issues in fabrication." This limit is for $\mathrm{Na}$ and $\mathrm{K}$, no limit given for $\mathrm{Rb}$ and $\mathrm{Cs}$.

The FIT 2 estimates (figure B5) are almost identical as FIT 1 because both FIT 2 and FIT 1 divide elements by chemical group. The estimates are well within the presumed $\sim 500 \mathrm{ppm}$ limit.

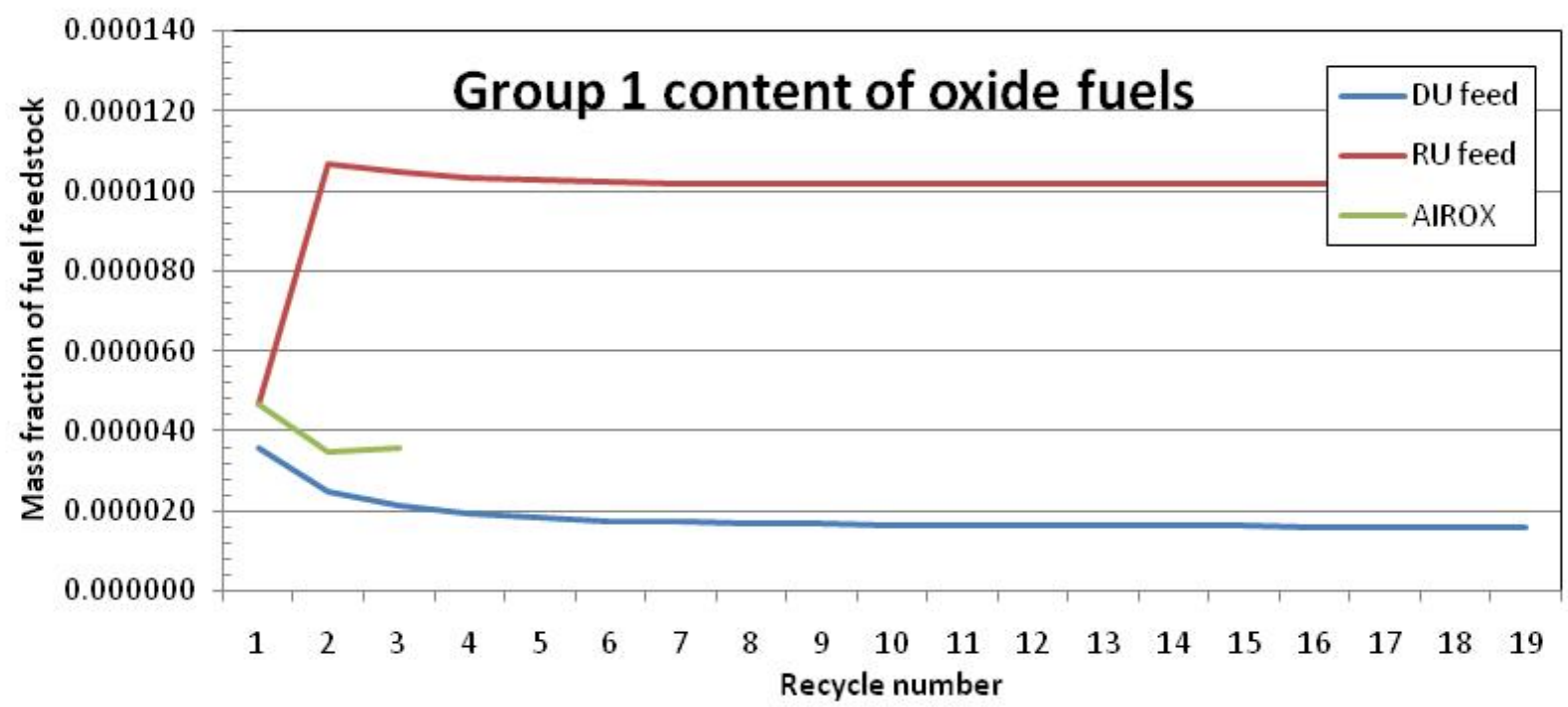

Figure B5. Group1 content for fast reactor oxide fuel, UREX+1 is always used on used LWR-UOX.

\section{Group 2 alkaline earth metals (Sr, Ba) - within limits}

The 2009 working limit from the Fuels Campaign is 330 ppm because "Tramp fission product. Carryover limited to minimize displacement of fissile content." This limit is for Sr. The FIT 2 results (figure B6) are about the same as the FIT 1 results. 


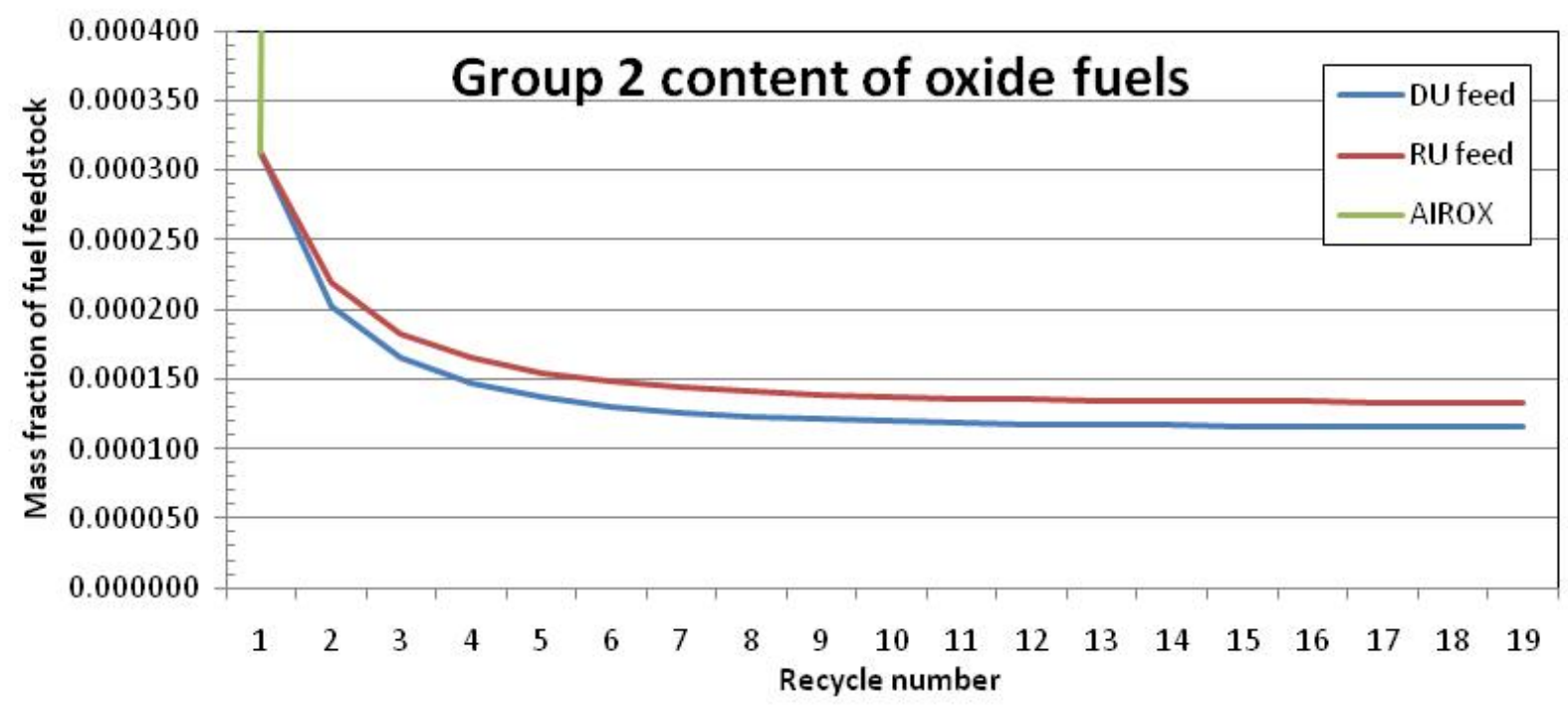

Figure B6. Group2 content for fast reactor oxide fuel, UREX+1 is always used on used LWR-UOX.

\section{Molybdenum and silver - exceed limits}

The 2009 working limit from the Fuels Campaign is 660 ppm because "Transition metals form undesirable oxides in the fuel and affect the total impurities displacing fissile content." This limit is for Ti, V, Mn, Co, Cu, Mo, Ag, Ta, W. Of these, only Mo and Ag are fission products. The FIT 2 estimates in figure B7 are about three times higher than the FIT 1 estimates for UREX+1 cases.

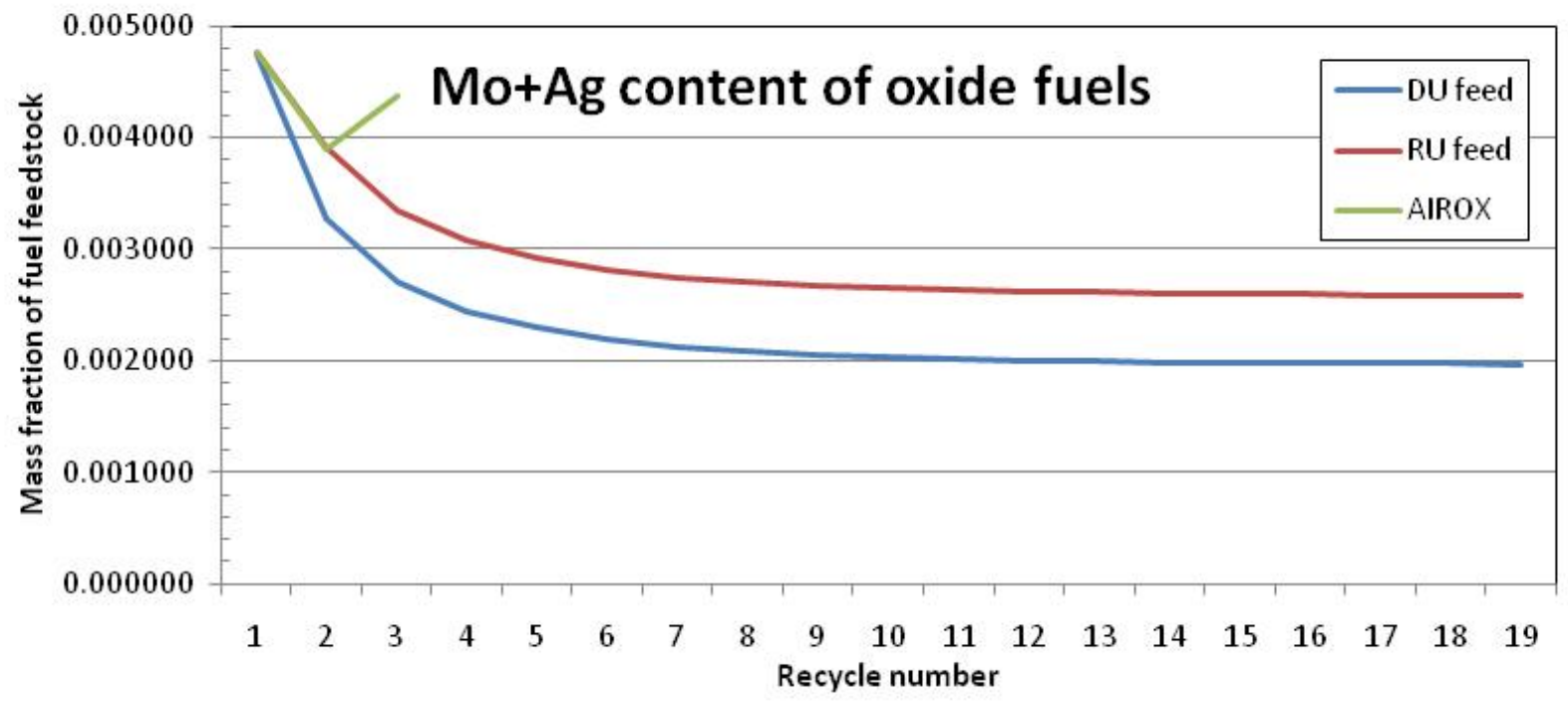

Figure B7. Mo+Ag content for fast reactor oxide fuel, UREX+1 is always used on used LWR-UOX.

\section{Ruthenium - exceed limits}

The 2009 working limit from the Fuels Campaign is $330 \mathrm{ppm}(0.000330)$ due to "Tramp fission product. Carryover limited to minimize displacement of fissile content." The estimated Ru impurity in FIT 2 in figure B8 for UREX+1 cases are quadruple those of FIT 1. 


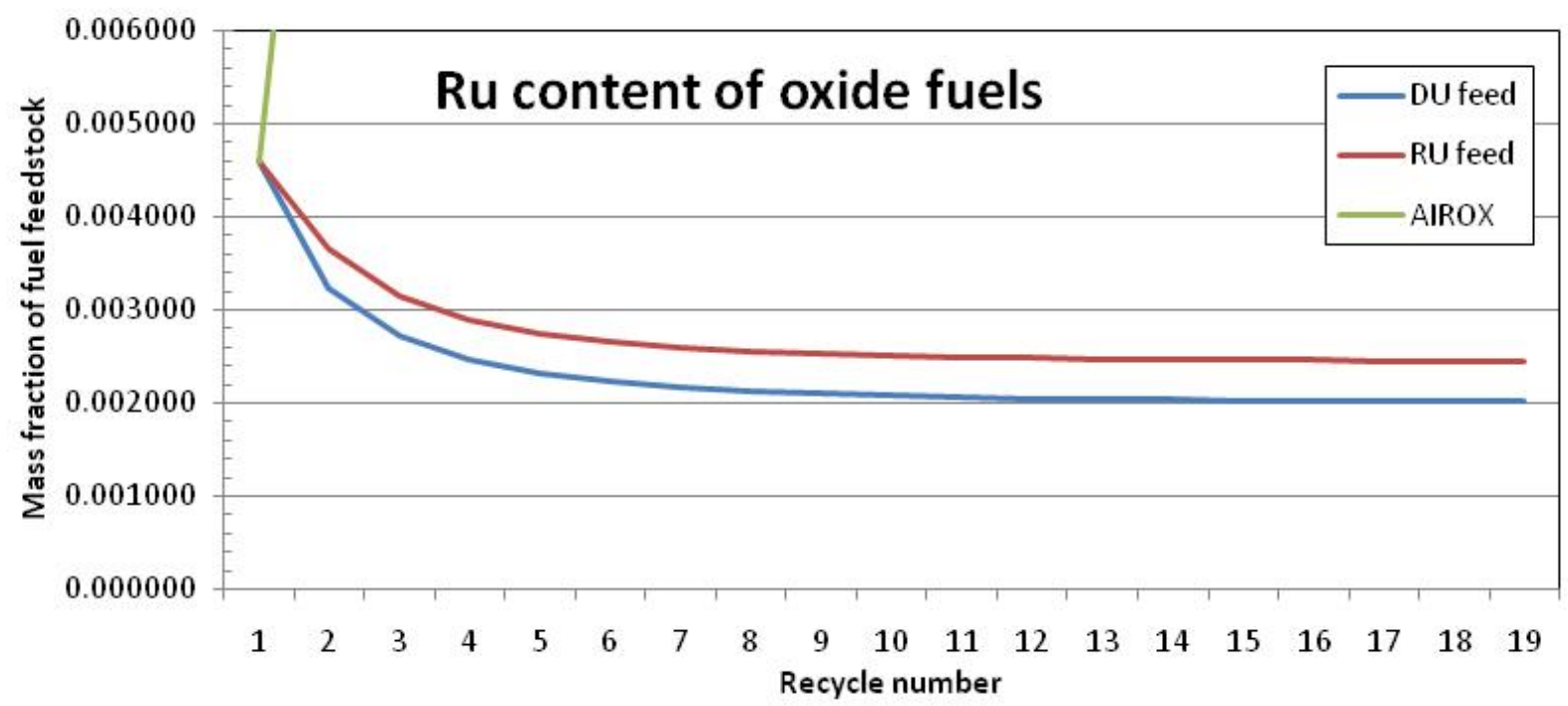

Figure B8. Ru content for fast reactor oxide fuel, UREX +1 is always used on used LWR-UOX8

\section{Cadmium and tin - exceed limits}

The 2009 working limit from the Fuels Campaign is 145 ppm (0.000145) due to "Low melting point metals that form oxides which decompose at temperatures below the fuel sintering temperature causing issues in fabrication." This limit is for $\mathrm{Zn}, \mathrm{Cd}, \mathrm{Sn}$, and $\mathrm{Pb}$. Of these, only $\mathrm{Cd}$ and $\mathrm{Sn}$ are fission products. This limit is not predicted to be met by UREX +1 , whether the uranium source is DU or RU. The estimated $\mathrm{Cd}+\mathrm{Sn}$ impurity in FIT $2 \mathrm{UREX}+1$ cases are about double that of FIT 1 . AIROX performance is actually reasonable because of Cd volatility, which is captured by element-specific estimates in FIT 2 (figure B9) but was not captured in FIT 1 because Cd was grouped with less volatile elements.

Voloxidation as a first step would seem to offer the potential for improved performance of UREX +1 .

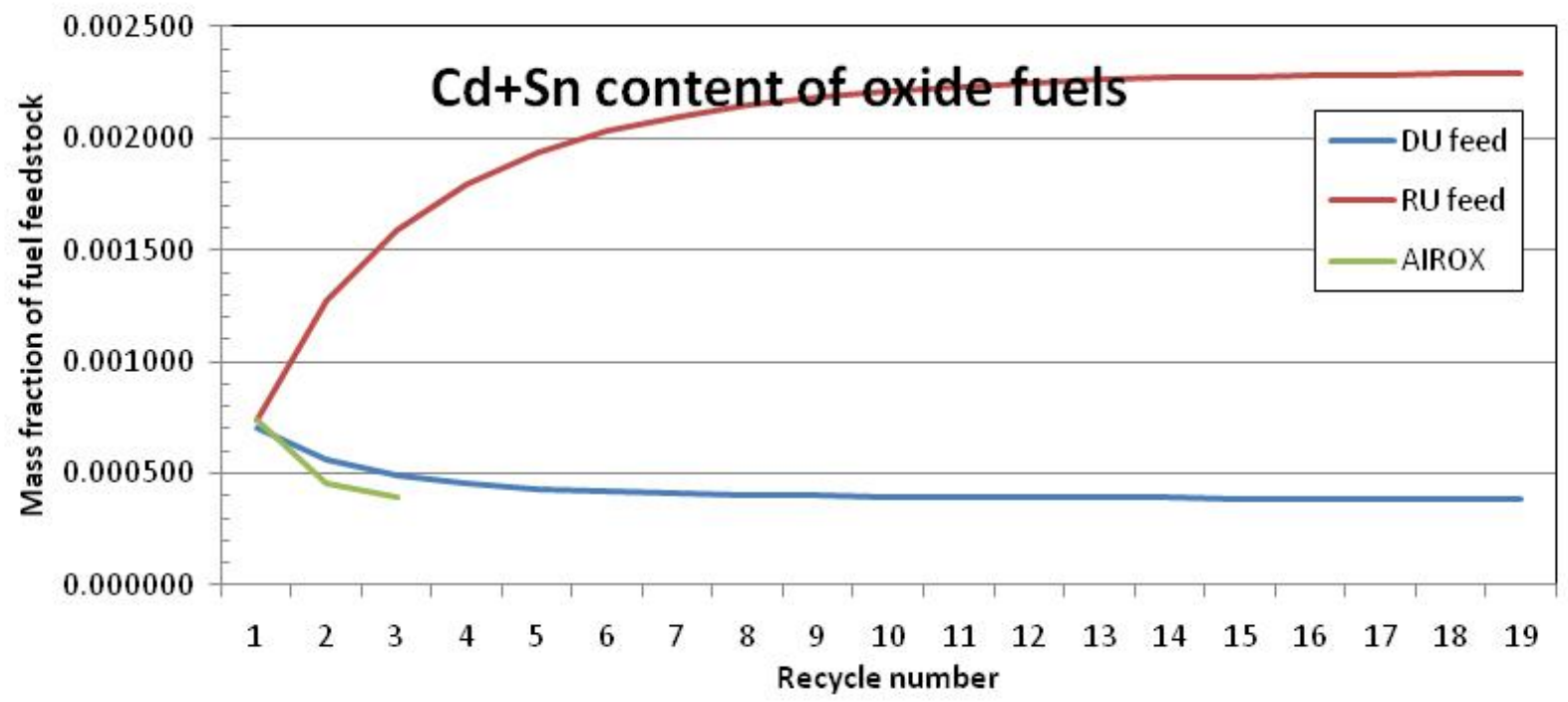

Figure B9. Cd+Sn content for fast reactor oxide fuel, UREX+1 is always used on used LWR-UOX 


\section{Elements not limited as of 2009}

Table B2 shows the range of estimates for which no oxide fuel limit currently exists. It is important to know if these levels of impurities would be an issue for oxide fuel fabrication and performance. The maximum occurs when RU is the feed, the minimum occurs when DU is the feed. Relative to FIT 1, the FIT 2 results are ...

- Higher for $\mathrm{Pd}$, as well as lanthanides, $\mathrm{Mo}+\mathrm{Ag}, \mathrm{Ru}, \mathrm{Cd}+\mathrm{Sn}$ discussed above

- Lower for $\mathrm{Se}, \mathrm{Nb}, \mathrm{Rh}, \mathrm{In}$, and $\mathrm{Te}$

- About the same for Zr, Tc, Group1, Group 2 (handled as an individual element in both FIT 2 and FIT 1) and for Sb.

Table B2. Estimates of Fuel Impurities for which no oxide fuel limit exists (UREX +1 separation of both $\mathrm{UOX}$ and $\mathrm{FR}$ at $\mathrm{CR}=0.50$ ).

\begin{tabular}{|l|c|c|c|c|c|c|c|c|c|}
\hline $\begin{array}{l}\text { Estimate in } \\
\text { ppm }\end{array}$ & $\mathrm{Se}$ & $\mathrm{Zr}$ & $\mathrm{Nb}$ & $\mathrm{Tc}$ & $\mathrm{Rh}$ & $\mathrm{Pd}$ & $\mathrm{In}$ & $\mathrm{Sb}$ & $\mathrm{Te}$ \\
\hline FIT 2 - max & 4 & 600 & 0.1 & 200 & 50 & 9200 & 0.1 & 30 & 200 \\
\hline FIT 1 - max & 30 & 600 & 20 & 200 & 200 & 2000 & 10 & 30 & 500 \\
\hline FIT 2 - min & 1 & 200 & 0.003 & 90 & 20 & 5000 & 0.1 & 10 & 10 \\
\hline FIT 1 - min & 10 & 200 & 10 & 90 & 90 & 1000 & 1 & 10 & 200 \\
\hline
\end{tabular}

\section{B.2.3 Metal fuel with melt refining}

If melt refining is used on used LWR-UOX (case 4), fast reactor fuel cannot be made and FIT stops immediately.

If UREX+1 is used on used LWR-UOX and melt refining is used on fast reactor fuel (case 3), 3 recycles are possible from the physics standpoint. Figure B10 shows the actinide and total impurities for the oxide fuel case in which melt refining is used to recycled used FR fuel. Recycle 1 has low impurities since it uses only feed from UREX +1 separation of used UOX-51 fuel. Thereafter the impurities increase substantially as FIT blends used UOX-51 (from UREX+1) with used FR fuel that has been separated with melt refining. The model cannot proceed past 3 recycles because the impurities become too high to maintain criticality, even with no uranium dilution from UREX+1, i.e., the model attempts to make recycle-4 using only TRU from UREX +1 treatment of UOX-51 plus melt refining feed from treatment of used FR fuel.

Figure B10 shows the overall composition as a function of melt refining. 


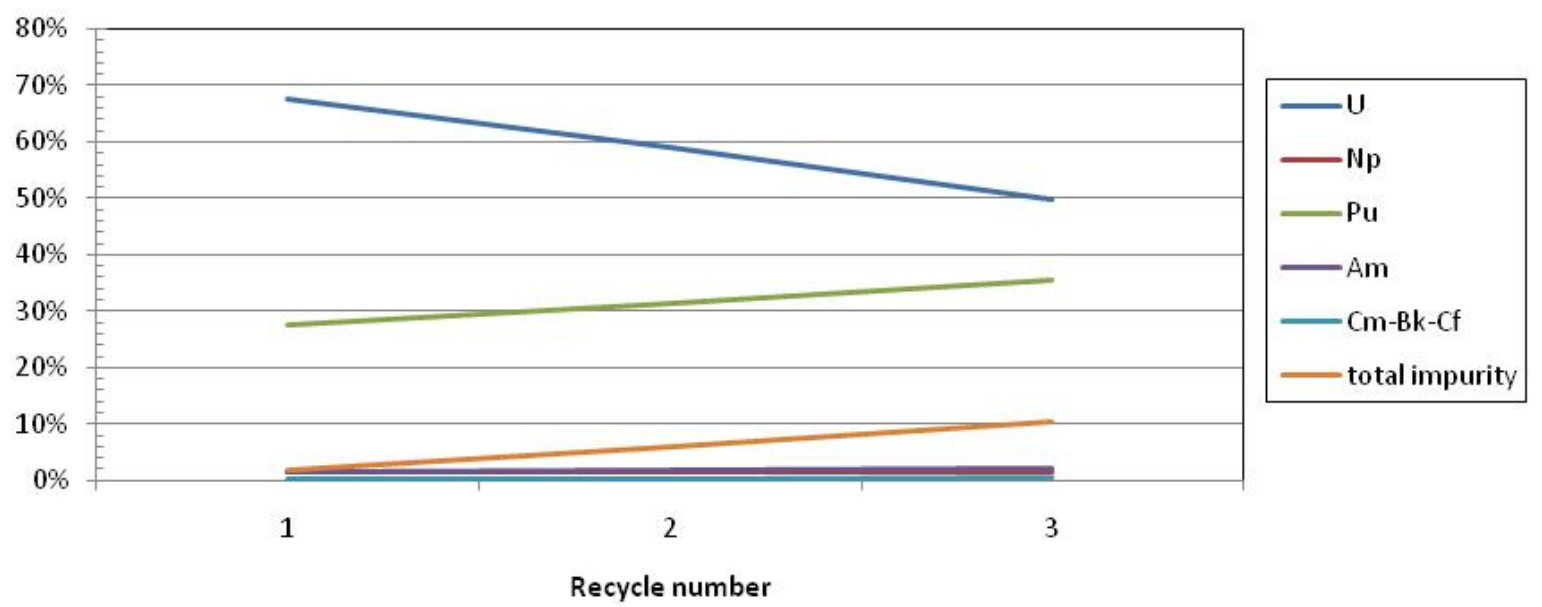

Figure B10. Composition for fast reactor metal fuel: UREX+1 on LWR-UOX fuel and melt refining on FR fuel.

\section{B.2.4 Metal fuel with electrochemical refining of fast reactor fuel}

This focus of this subsection is UREX +1 separation on used LWR-UOX and electrochemical on used fast reactor fuel. (Exception: the graphs also include the case of UREX +1 separation on used LWR-UOX and melt refining on used fast reactor fuel.) The source of uranium for dilution is either RU-1/RU-2 (case 1) or DU (case 2). Only when recovered uranium has significant impurities relative to the impurities that come with TRU do the RU vs. DU results differ significantly. Of course, the estimated impurities with $\mathrm{RU}$ are always higher than DU feed; DU is assumed chemically pure.

Figures B11 and B12 show the overall composition of fast reactor fuel from repeated recycling.

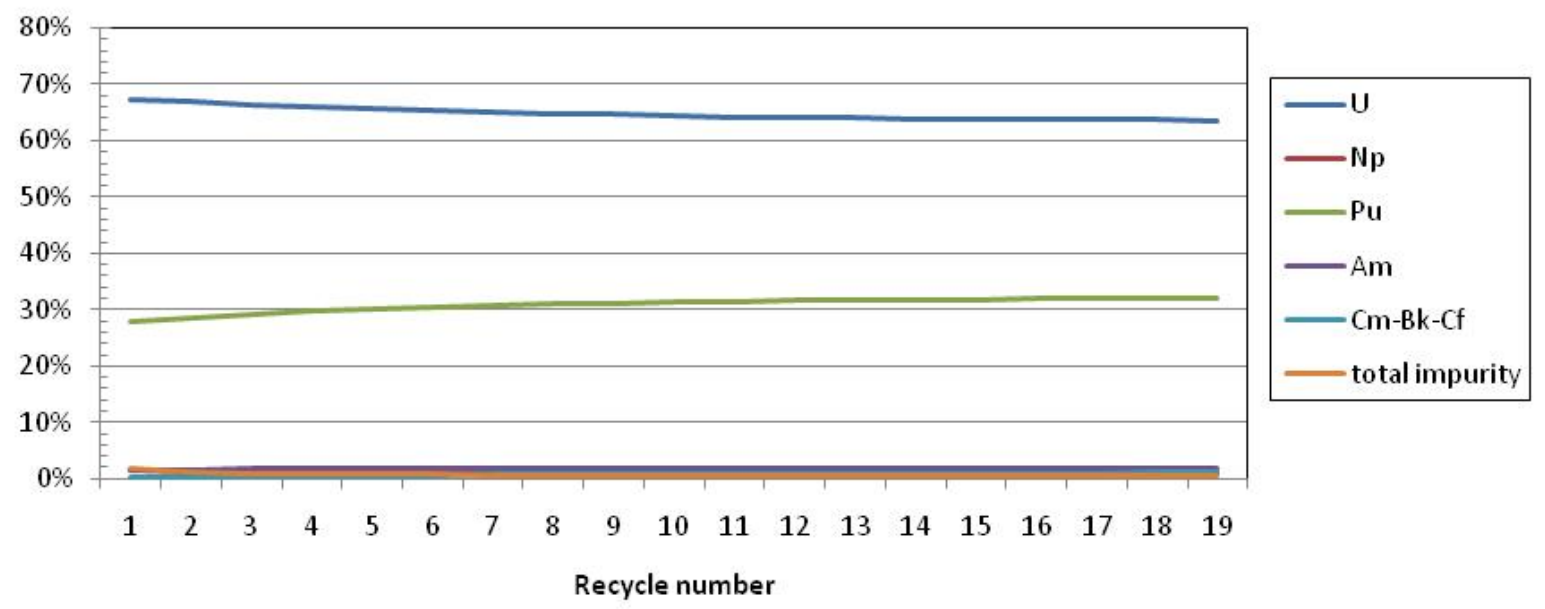

Figure B11. Composition for fast reactor metal fuel: UREX+1 on LWR-UOX and FR fuel, RU feed. 


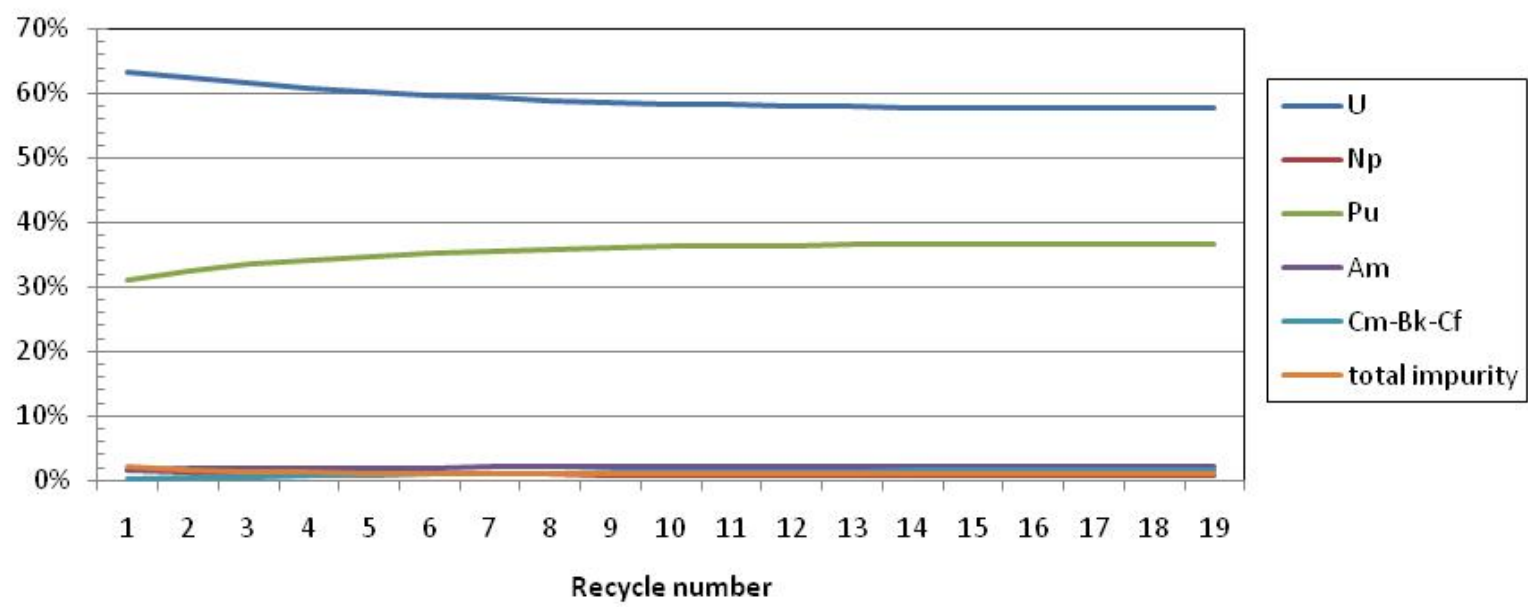

Figure B12. Composition for fast reactor metal fuel: UREX+1 on LWR-UOX and FR fuel, DU feed.

\section{Lanthanides - exceed limits}

The 2009 working limit from the Fuels Campaign is 775 ppm - "Concentrations of rare earth elements form low melting eutectics with fuel cladding. Rare earth feedstock impurities are more detrimental to fuel due to their lack of dispersion." This limit is given for all lanthanides.

Figure B13 shows that the working limit would be exceeded for electrochemical recycling of used FR fuel (either RU or DU feed). Melt refining actually performs well because the original melt refining experiments used a crucible that oxidized the lanthanides, which were then scrapped off the melt. The FIT 2 results are similar but a bit lower than the FIT 1 estimates.

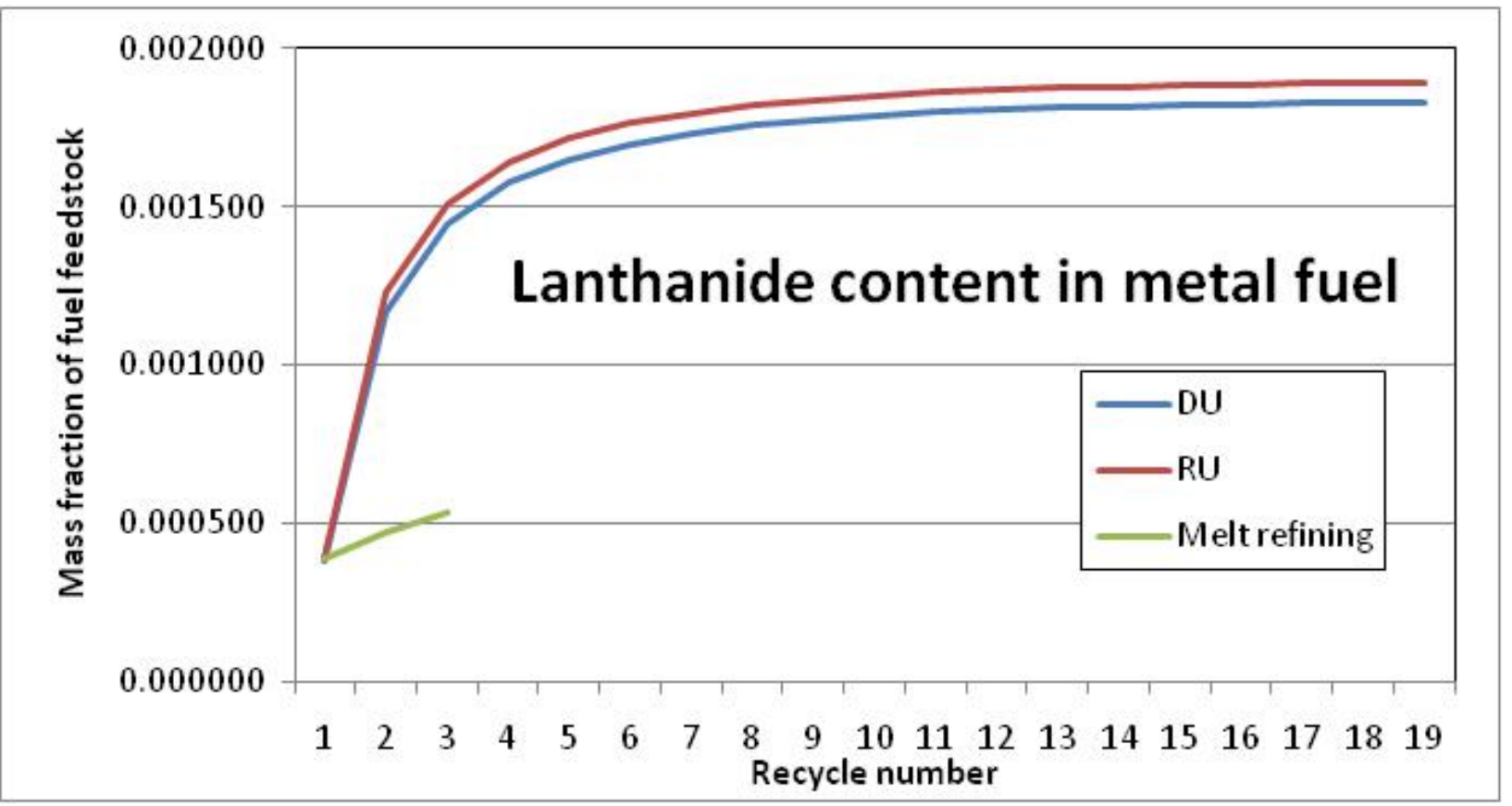

Figure B13. Lanthanide content for fast reactor metal fuel, UREX+1 is always used on used LWR-UOX. 


\section{Molybdenum - exceed limits}

The 2009 working limit from the Fuels Campaign is 465 ppm - "Transition metals form undesirable intermetallics in the fuel and affect the total impurities displacing fissile content." This limit applies to $\mathrm{Al}, \mathrm{Cr}, \mathrm{Mn}, \mathrm{Fe}, \mathrm{Ni}, \mathrm{Zn}, \mathrm{Mo}$; of these, only Mo is a fission product. However, we are aware of the concept of adding Mo to the fuel alloy, from which we infer that Mo may not be limited to this value. The FIT 2 estimates are significantly higher than FIT 1 and higher than the 2009 working limit.

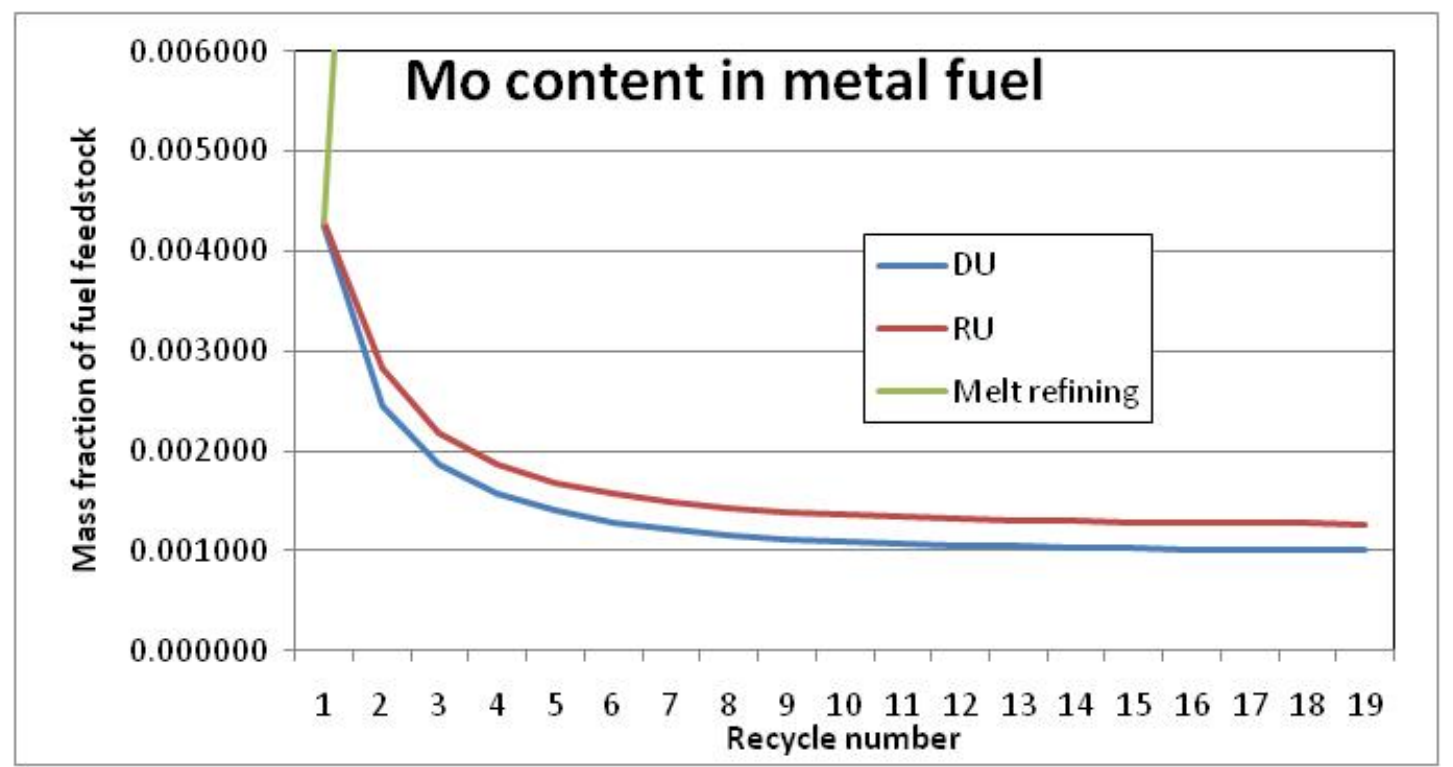

Figure B14. Molybdenum content for fast reactor metal fuel, UREX+1 is always used on used LWRUOX.

\section{Cadmium - within limits}

The 2009 working limit from the Fuels Campaign is 200 ppm because of "limited carryover from electrochemical separations". The nominal separation factors do not indicate a problem, even though Cd stems from both UREX+1 (on LWR-UOX) and electrochemical (on FR metal fuel). The FIT 2 estimates are lower than the FIT 1 estimates. 


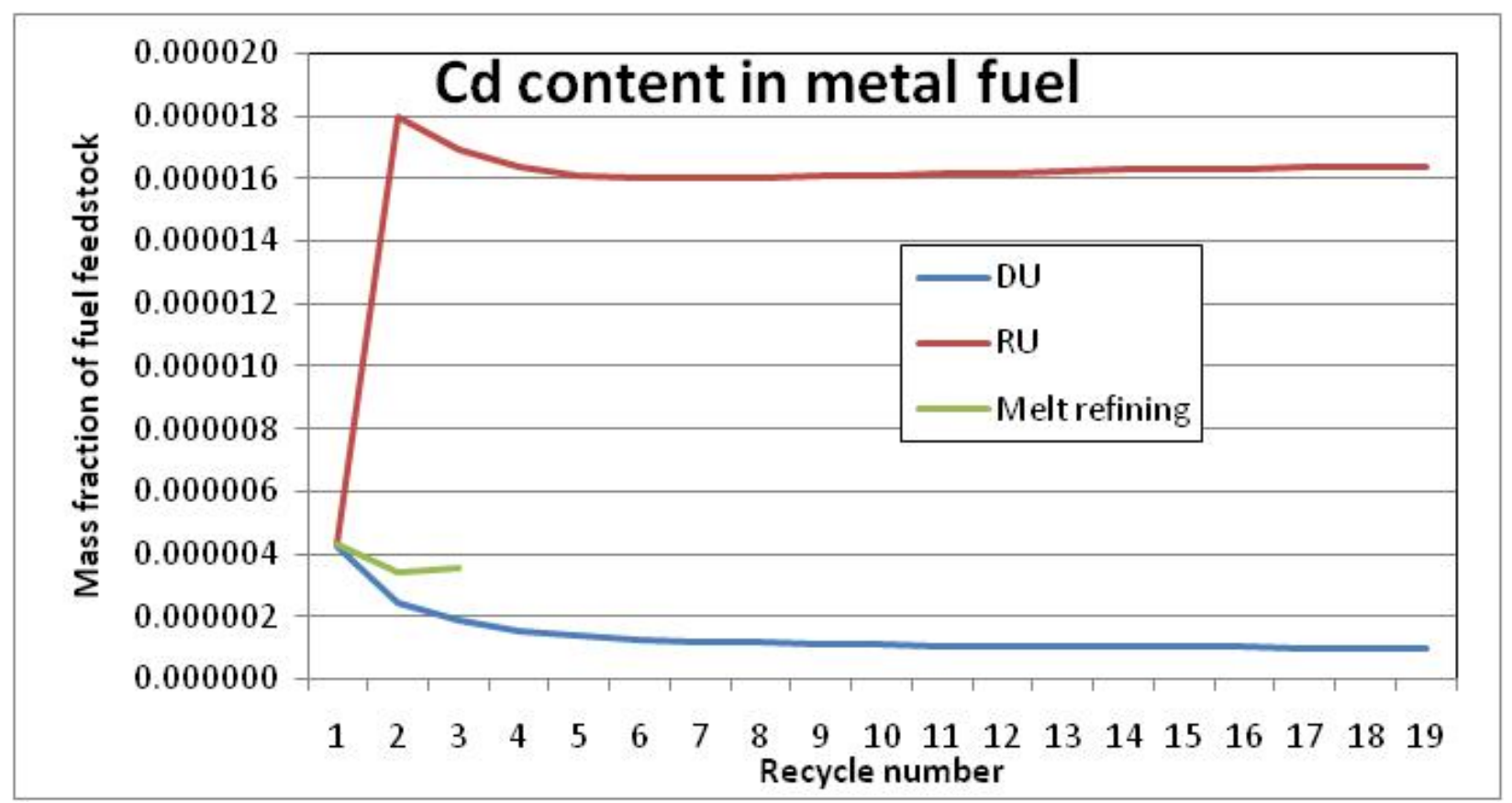

Figure B15. Cadmium content for fast reactor metal fuel, UREX+1 is always used on used LWR-UOX

\section{Elements not currently limited}

Table B3 shows the range of estimates for which no oxide fuel limit currently exists. It is important to know if these levels of impurities would be an issue for oxide fuel fabrication and performance. The maximum occurs when RU is the feed, the minimum occurs when DU is the feed. Relative to FIT 1, the FIT 2 results are ...

- Higher for Ru, Pd, Sn, as well as Mo discussed above

- Lower for $\mathrm{Nb}, \mathrm{Rh}, \mathrm{Ag}, \mathrm{In}$, and $\mathrm{Te}$, as well as $\mathrm{Cd}$ discussed above

- About the same for Lanthanides, Zr, Tc, Group1, Group 2 (handled as an individual element in both FIT 2 and FIT 1) and for Se, Sb.

Table B3. Estimates of fuel impurities for which no metal fuel limit exists (UREX+1 separation of UOX and electrochemical separation of $\mathrm{FR}$ at $\mathrm{CR}=0.50$ ).

\begin{tabular}{|l|c|c|c|c|c|c|c|c|c|c|c|c|c|}
\hline $\begin{array}{l}\text { Estimate } \\
\text { in ppm }\end{array}$ & $\begin{array}{c}\mathrm{Gr} \\
1\end{array}$ & $\begin{array}{c}\mathrm{Gr} \\
2\end{array}$ & $\mathrm{Se}$ & $\mathrm{Nb}$ & $\mathrm{Tc}$ & $\mathrm{Ru}$ & $\mathrm{Rh}$ & $\mathrm{Pd}$ & $\mathrm{Ag}$ & $\mathrm{In}$ & $\mathrm{Sn}$ & $\mathrm{Sb}$ & $\mathrm{Te}$ \\
\hline $\begin{array}{l}\text { FIT 2 }- \\
\max \end{array}$ & 50 & 300 & 30 & 0.5 & 200 & 4000 & 130 & 8300 & 2 & 1 & 630 & 30 & 50 \\
\hline $\begin{array}{l}\text { FIT 1 - } \\
\max \end{array}$ & 50 & 300 & 20 & 10 & 200 & 500 & 200 & 1500 & 200 & 10 & 300 & 20 & 500 \\
\hline $\begin{array}{l}\text { FIT 2 - } \\
\text { min }\end{array}$ & 10 & 70 & 0.5 & 0.001 & 50 & 1000 & 10 & 2000 & 0.4 & 0.02 & 150 & 6 & 4 \\
\hline $\begin{array}{l}\text { FIT 1 - } \\
\text { min }\end{array}$ & 10 & 70 & 6 & 3 & 50 & 100 & 40 & 400 & 40 & 1 & 60 & 6 & 100 \\
\hline
\end{tabular}




\section{Appendix C}

\section{Illustrative Waste Results using a UREX+1 Example Case}


This page intentionally left blank. 


\section{C.1 Illustration of Waste Form Information}

The FIT model contains formats for the user to specify such parameters as the waste loading and waste form density for each waste stream, as shown in Figure C1. This figure shows a snapshot at iteration 19 for the grouted waste forms for the tritium and C-14 separated from the used fuel. Tabs are available for each of the output waste streams to convert the mass rate of each waste stream to its corresponding waste form mass and volume rates.

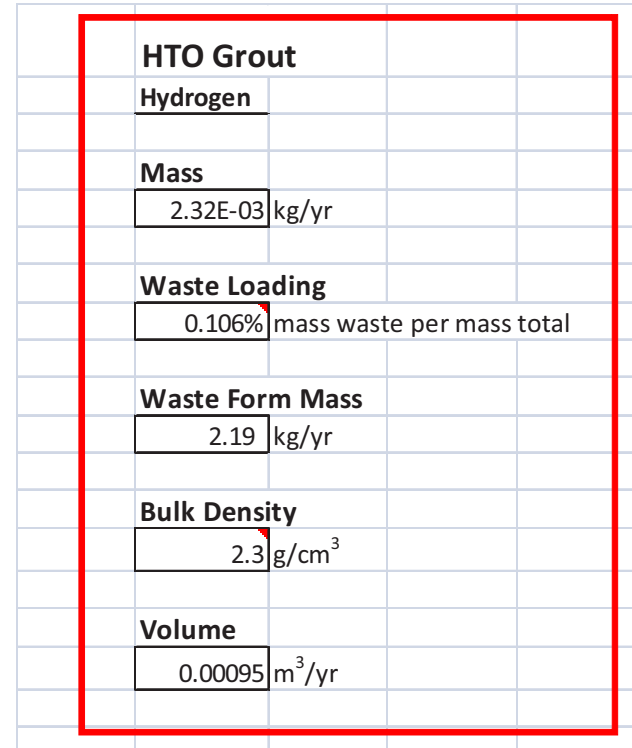

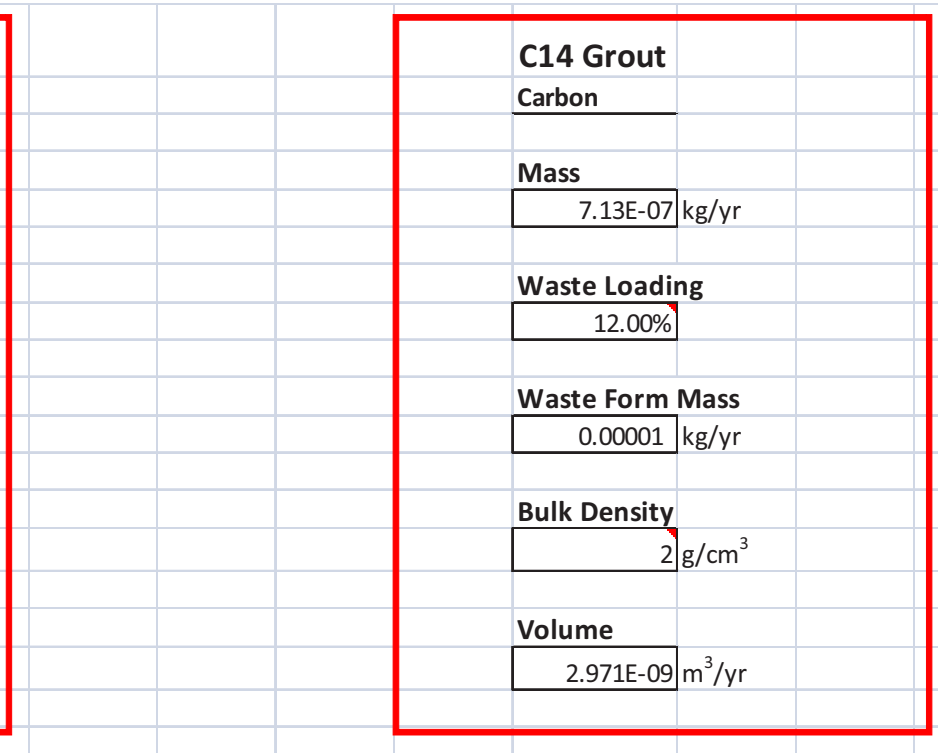

Figure $\mathrm{C} 1$. Cells for documenting waste stream mass from separations, user-input values for waste loading and waste form density, and resultant final waste form mass and volume.

Figure $\mathrm{C} 2$ shows how, after multiple recycles, the mass and volume of each waste stream (in this case the borosilicate glass waste form) asymptotically approaches a maximum value. 


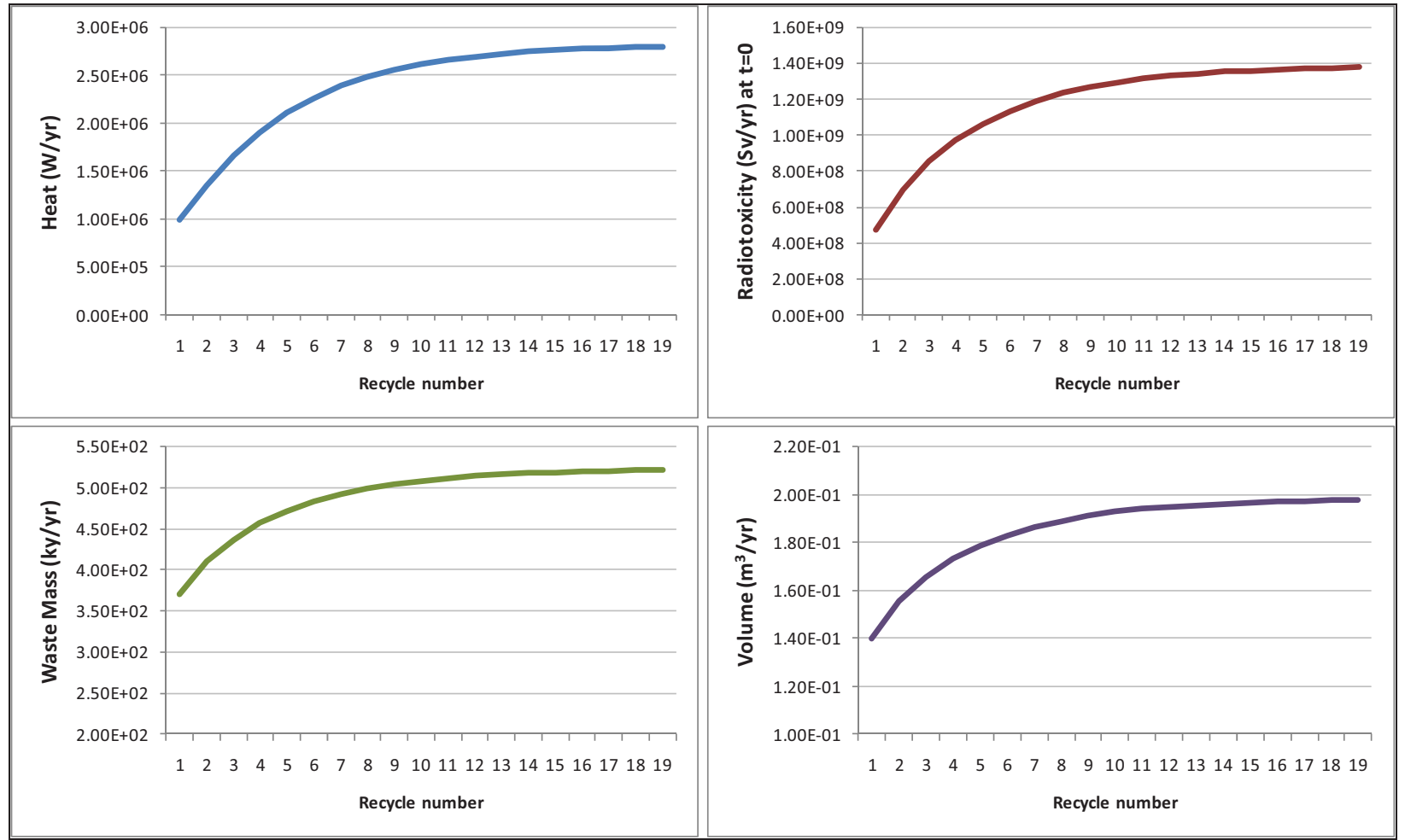

Figure C2. Waste stream output for the BSG waste form for Case 5.

The model also provides key parameters for each waste stream in the "output" worksheet, as shown in Figure C3. The blocks of data in this figure illustrate the output waste streams in the model for UREX +1 separations, with the case information shown in the first block (Case 5, UREX+1 for both sep1 and sep 2, UDS in Tc metal waste form instead of added to the FP borosilicate glass [BSG]), and lanthanides in a separate lanthanide glass waste form. In addition, this option includes a separate mineralized $\mathrm{Cs} / \mathrm{Sr}$ waste form instead of combination of the $\mathrm{Cs} / \mathrm{Sr}$ waste in with the FP BSG waste form.

Waste streams for this UREX +1 separations case are shown in figure C3. Waste streams for other separations and recycle cases are tailored for those separations matrices, which are shown in Appendix A. 


\begin{tabular}{|c|c|c|c|c|c|c|c|c|c|c|c|c|c|}
\hline & & & & & & & & W (From Deca) & ayed Storage) & & & & \\
\hline Simula & Settings & & Iteration & $\begin{array}{l}\text { Heat } \\
(\mathrm{W} / \mathrm{yr})\end{array}$ & $\begin{array}{l}\text { Gamma } \\
\text { (W/yr) }\end{array}$ & $\begin{array}{l}\text { Neutron } \\
\text { (W/yr) }\end{array}$ & $\begin{array}{l}\text { Neutron } \\
(\# / s / y r)\end{array}$ & $\begin{array}{l}\text { Radiotoxicity } \\
\text { (Sv/yr) at } t=0\end{array}$ & $\begin{array}{l}\text { Kaciocuxicity } \\
(\text { Sv/yr) at } \\
t=10,000 \mathrm{yr}\end{array}$ & $\begin{array}{l}\text { 10CFR } \\
\text { C sum }\end{array}$ & $\begin{array}{l}\text { ER61 Class } \\
m\end{array}$ & $\begin{array}{l}\text { Mass } \\
(\mathrm{kg} / \mathrm{yr})\end{array}$ & $\begin{array}{l}\text { Volume } \\
\text { (m3/yr) }\end{array}$ \\
\hline & & & 1 & $4.80 E+01 \quad 2$ & $2.00 E+00$ & $0.00 \mathrm{E}+00$ & $0.00 E+00$ & ) $1.74 \mathrm{E}-290$ & $\begin{array}{ll}0 & 1.74 E-290 \\
\end{array}$ & & $9.75 E-07$ & $1.81 \mathrm{E}+$ & $E+02 \quad 9.61 E-01$ \\
\hline Storage before Sep1: & & & 2 & $5.07 \mathrm{E}+012$ & $2.11 \mathrm{E}+00$ & $0.00 \mathrm{E}+00$ & $0.00 E+00$ & $2.88 \mathrm{E}-290$ & $2.87 \mathrm{E}-290$ & & $1.25 \mathrm{E}-06$ & $1.91 \mathrm{E}+$ & $\mathrm{E}+02 \quad 1.01 \mathrm{E}+00$ \\
\hline & & 4 & 3 & $5.26 \mathrm{E}+01 \quad 2$ & $2.19 E+00$ & $0.00 E+00$ & $0.00 E+00$ & $3.69 \mathrm{E}-290$ & $3.68 \mathrm{E}-290$ & & $1.43 \mathrm{E}-06$ & $1.98 \mathrm{E}+$ & $E+02 \quad 1.05 E+00$ \\
\hline Separations 1: & & & 4 & $5.41 \mathrm{E}+012$ & $2.25 E+00$ & $0.00 E+00$ & $0.00 E+00$ & $4.27 E-290$ & $4.26 \mathrm{E}-290$ & & $1.57 \mathrm{E}-06$ & $2.03 E+$ & $\mathrm{E}+02 \quad 1.08 \mathrm{E}+00$ \\
\hline & & UREX+1A & 5 & $5.51 \mathrm{E}+01 \quad 2$ & $2.30 \mathrm{E}+00$ & $0.00 \mathrm{E}+00$ & $0.00 E+00$ & $4.71 \mathrm{E}-290$ & $4.69 \mathrm{E}-290$ & & $1.67 \mathrm{E}-06$ & 2.07E+ & $\begin{array}{ll}E+02 & 1.10 E+00\end{array}$ \\
\hline Sep1 Storage (yrs): & & & 6 & $5.59 \mathrm{E}+01 \quad 2$ & $2.33 \mathrm{E}+00$ & $0.00 \mathrm{E}+00$ & $0.00 E+00$ & $5.02 \mathrm{E}-290$ & $5.01 E-290$ & & $1.74 \mathrm{E}-06$ & 2.09E+ & $\mathrm{E}+02 \quad 1.11 \mathrm{E}+00$ \\
\hline & & & 7 & $5.64 \mathrm{E}+01 \quad 2$ & $2.35 E+00$ & $0.00 \mathrm{E}+00$ & $0.00 \mathrm{E}+00$ & $5.26 \mathrm{E}-290$ & $5.25 \mathrm{E}-290$ & & $1.79 \mathrm{E}-06$ & $2.11 \mathrm{E}+$ & $E+02 \quad 1.12 E+00$ \\
\hline$\%$ UREX+1a separations & ig to UDS: & & 8 & $5.69 E+01 \quad 2$ & $2.37 E+00$ & $0.00 E+00$ & $0.00 E+00$ & $5.44 E-290$ & $5.42 E-290$ & & $1.83 \mathrm{E}-06$ & $2.13 E+$ & $E+02 \quad 1.13 E+00$ \\
\hline & & $1.00 \%$ & 9 & $5.72 \mathrm{E}+012$ & $2.38 \mathrm{E}+00$ & $0.00 E+00$ & $0.00 E+00$ & $5.57 \mathrm{E}-290$ & $5.56 \mathrm{E}-290$ & & $1.86 \mathrm{E}-06$ & 2.14Et & $\mathrm{E}+02 \quad 1.14 \mathrm{E}+00$ \\
\hline Reactor: & & & 10 & $5.74 E+012$ & $2.39 E+00$ & $0.00 \mathrm{E}+00$ & $0.00 E+00$ & $5.67 \mathrm{E}-290$ & $5.66 \mathrm{E}-290$ & & $1.89 \mathrm{E}-06$ & $2.15 E+$ & $E+02 \quad 1.14 E+00$ \\
\hline Fast Reactor, Oxide Fu & $R=0.5$, startup $c$ & composition & 11 & $5.76 \mathrm{E}+01 \quad 2$ & $2.40 E+00$ & $0.00 \mathrm{E}+00$ & $0.00 E+00$ & $5.75 \mathrm{E}-290$ & $5.73 E-290$ & & $1.91 \mathrm{E}-06$ & $2.16 \mathrm{E}+$ & $E+02 \quad 1.15 E+00$ \\
\hline Rx Storage (yrs): & & & 12 & $5.77 \mathrm{E}+012$ & $2.41 E+00$ & $0.00 \mathrm{E}+00$ & $0.00 \mathrm{E}+00$ & $5.80 \mathrm{E}-290$ & $5.79 \mathrm{E}-290$ & & $1.92 \mathrm{E}-06$ & $2.16 \mathrm{E}+$ & $E+02 \quad 1.15 E+00$ \\
\hline & & 1 & 13 & $5.79 E+01 \quad 2$ & $2.41 E+00$ & $0.00 E+00$ & $0.00 E+00$ & $5.85 E-290$ & $5.83 \mathrm{E}-290$ & & $1.93 \mathrm{E}-06$ & $2.17 \mathrm{E}+$ & $E+02 \quad 1.15 E+00$ \\
\hline Separations 2: & & & 14 & $5.79 E+01 \quad 2$ & $2.42 E+00$ & $0.00 E+00$ & $0.00 E+00$ & $5.88 \mathrm{E}-290$ & $5.86 \mathrm{E}-290$ & & $1.94 \mathrm{E}-06$ & $2.17 \mathrm{E}+$ & $E+02 \quad 1.15 E+00$ \\
\hline & & UREX+1A & 15 & $5.80 \mathrm{E}+012$ & $2.42 E+00$ & $0.00 E+00$ & $0.00 E+00$ & $5.91 E-290$ & $5.89 \mathrm{E}-290$ & & $1.95 \mathrm{E}-06$ & $2.17 \mathrm{E}+$ & $E+02 \quad 1.15 E+00$ \\
\hline Sep2 Storage (yrs): & & & 16 & $5.80 \mathrm{E}+01 \quad 2$ & $2.42 E+00$ & $0.00 E+00$ & $0.00 E+00$ & $5.93 \mathrm{E}-290$ & $5.91 \mathrm{E}-290$ & & $1.95 \mathrm{E}-06$ & $2.17 \mathrm{E}+$ & $E+02 \quad 1.15 E+00$ \\
\hline & & & 17 & $5.81 \mathrm{E}+01 \quad 2$ & $2.42 E+00$ & $0.00 E+00$ & $0.00 E+00$ & $5.94 \mathrm{E}-290$ & $5.92 E-290$ & & $1.96 \mathrm{E}-06$ & $2.17 \mathrm{E}+$ & $E+02 \quad 1.15 E+00$ \\
\hline Uranium: & & & 18 & $5.81 \mathrm{E}+012$ & $2.42 E+00$ & $0.00 E+00$ & $0.00 E+00$ & $5.95 E-290$ & $5.94 E-290$ & & $1.96 \mathrm{E}-06$ & $2.18 \mathrm{E}+$ & $E+02 \quad 1.16 E+00$ \\
\hline & & Use RU-2 & 19 & $5.81 \mathrm{E}+01 \quad 2$ & $2.42 E+00$ & $0.00 E+00$ & $0.00 E+00$ & $5.96 \mathrm{E}-290$ & $5.95 E-290$ & & $1.96 \mathrm{E}-06$ & $2.18 \mathrm{E}+$ & $E+02 \quad 1.16 E+00$ \\
\hline UDS goes to Glass (URE & & & & & & & & & & & & & \\
\hline & & FALSE & & & & & & & & & & & \\
\hline Lanthinides Combine & HLW Glass: & & & & & & & & & & & & \\
\hline & & FALSE & & & & & & & & & & & \\
\hline & IT 2.0 new_sep_case & se5.xlsm]Output & & & & & & & & & & & \\
\hline & & & & MLL & LLW (Fr & rom Dec & caye & orage) & & & & & \\
\hline & & & & & & & & XICITY & & & & & \\
\hline Iteration & $\begin{array}{l}\text { Heat } \\
(W / y r)\end{array}$ & $\begin{array}{l}\text { Gamma } \\
\text { (W/yr) }\end{array}$ & $\begin{array}{l}\text { Neutron } \\
\text { (W/yr) }\end{array}$ & $\begin{array}{l}\text { Neutron } \\
\text { (\#/s/yr) }\end{array}$ & $\begin{array}{l}\text { Radio } \\
\text { (Sv/y }\end{array}$ & $\begin{array}{l}\text { otoxicity } \\
\text { yr) at } t=0\end{array}$ & $\begin{array}{l}(\mathrm{Sv} / \mathrm{y} \\
\mathrm{t}=10,\end{array}$ & $\begin{array}{l}\text { r) at } \\
000 \mathrm{yr}\end{array}$ & $\begin{array}{l}\text { 10CFR61 Cl } \\
\text { C sum }\end{array}$ & lass & $\begin{array}{l}\text { Mass } \\
(\mathrm{kg} / \mathrm{yr})\end{array}$ & & $\begin{array}{l}\text { Volume } \\
\text { (m3/yr) }\end{array}$ \\
\hline 1 & $4.46 \mathrm{E}+06$ & $1.45 \mathrm{E}+01$ & $9.53 \mathrm{E}-08$ & $5.95 \mathrm{E}+05$ & & $3.36 \mathrm{E}+08$ & & $5.51 E+04$ & $2.35 \mathrm{E}$ & $E+01$ & $4.56 \mathrm{E}$ & $E+02$ & $5.52 \mathrm{E}-01$ \\
\hline 2 & $6.42 E+06$ & $1.54 \mathrm{E}+01$ & 2.04E-07 & $1.27 \mathrm{E}+06$ & & $3.55 \mathrm{E}+08$ & & $7.45 \mathrm{E}+04$ & $2.56 \mathrm{E}$ & $E+01$ & $4.88 \mathrm{E}-$ & $E+02$ & $5.92 \mathrm{E}-01$ \\
\hline 3 & $8.06 E+06$ & $1.60 E+01$ & 3.50E-07 & $2.18 E+06$ & & $3.69 \mathrm{E}+08$ & & $8.97 E+04$ & $2.71 \mathrm{E}$ & $E+01$ & $5.11 \mathrm{E}$ & $E+02$ & $6.20 \mathrm{E}-01$ \\
\hline 4 & $9.38 \mathrm{E}+06$ & $1.64 \mathrm{E}+01$ & $5.24 \mathrm{E}-07$ & $3.27 E+06$ & & $3.79 \mathrm{E}+08$ & & $1.01 E+05$ & $2.82 \mathrm{E}$ & $E+01$ & $5.28 \mathrm{E}$ & $E+02$ & $6.40 \mathrm{E}-01$ \\
\hline 5 & $1.04 \mathrm{E}+07$ & $1.68 \mathrm{E}+01$ & $7.18 \mathrm{E}-07$ & $4.48 \mathrm{E}+06$ & & $3.86 \mathrm{E}+08$ & & $1.11 \mathrm{E}+05$ & $2.91 \mathrm{E}$ & $E+01$ & $5.40 \mathrm{E}$ & $E+02$ & $6.55 \mathrm{E}-01$ \\
\hline 6 & $1.13 \mathrm{E}+07$ & 1.70E+01 & $9.20 \mathrm{E}-07$ & $5.74 \mathrm{E}+06$ & & $3.91 \mathrm{E}+08$ & & $1.18 \mathrm{E}+05$ & $2.97 \mathrm{E}$ & $E+01$ & $5.49 \mathrm{E}$ & $E+02$ & $6.66 \mathrm{E}-01$ \\
\hline 7 & $1.19 \mathrm{E}+07$ & $1.72 \mathrm{E}+01$ & 1.12E-06 & $7.02 E+06$ & & $3.95 \mathrm{E}+08$ & & $1.23 \mathrm{E}+05$ & $3.02 \mathrm{E}$ & $E+01$ & $5.56 \mathrm{E}$ & $E+02$ & $6.74 \mathrm{E}-01$ \\
\hline 8 & $1.24 \mathrm{E}+07$ & 1.73E+01 & $1.32 \mathrm{E}-06$ & $8.27 E+06$ & & $3.98 \mathrm{E}+08$ & & $1.27 \mathrm{E}+05$ & $3.06 \mathrm{E}$ & $E+01$ & $5.61 \mathrm{E}$ & $E+02$ & $6.81 \mathrm{E}-01$ \\
\hline 9 & $1.28 \mathrm{E}+07$ & 1.74E +01 & $1.52 \mathrm{E}-06$ & $9.46 \mathrm{E}+06$ & & 4.00E+08 & & $1.31 \mathrm{E}+05$ & $3.08 \mathrm{E}$ & $E+01$ & $5.65 \mathrm{E}$ & $E+02$ & $6.85 \mathrm{E}-01$ \\
\hline 10 & $1.31 \mathrm{E}+07$ & 1.75E+01 & 1.70E-06 & $1.06 \mathrm{E}+07$ & & $4.02 E+08$ & & $1.33 \mathrm{E}+05$ & $3.11 \mathrm{E}$ & $E+01$ & $5.68 \mathrm{E}$ & $E+02$ & $6.89 \mathrm{E}-01$ \\
\hline 11 & $1.33 \mathrm{E}+07$ & 1.76E+01 & $1.86 \mathrm{E}-06$ & $1.16 \mathrm{E}+07$ & & $4.03 E+08$ & & $1.35 \mathrm{E}+05$ & $3.12 \mathrm{E}$ & $E+01$ & $5.70 \mathrm{E}$ & $E+02$ & $6.91 \mathrm{E}-01$ \\
\hline 12 & $1.35 \mathrm{E}+07$ & $1.76 \mathrm{E}+01$ & 2.01E-06 & $1.26 \mathrm{E}+07$ & & $4.04 \mathrm{E}+08$ & & $1.36 \mathrm{E}+05$ & $3.13 \mathrm{E}$ & $E+01$ & $5.72 \mathrm{E}$ & $E+02$ & $6.93 \mathrm{E}-01$ \\
\hline 13 & $1.36 \mathrm{E}+07$ & 1.77E+01 & $2.15 \mathrm{E}-06$ & $1.34 \mathrm{E}+07$ & & $4.05 E+08$ & & $1.37 \mathrm{E}+05$ & $3.14 \mathrm{E}$ & $E+01$ & $5.73 \mathrm{E}$ & $E+02$ & $6.95 \mathrm{E}-01$ \\
\hline 14 & $1.37 \mathrm{E}+07$ & 1.77E+01 & 2.27E-06 & $1.42 \mathrm{E}+07$ & & $4.06 \mathrm{E}+08$ & & $1.38 \mathrm{E}+05$ & $3.15 \mathrm{E}$ & $E+01$ & $5.74 \mathrm{E}$ & $E+02$ & $6.96 \mathrm{E}-01$ \\
\hline 15 & $1.38 \mathrm{E}+07$ & 1.77E+01 & $2.38 \mathrm{E}-06$ & 1.49E+07 & & $4.06 \mathrm{E}+08$ & & $1.39 \mathrm{E}+05$ & $3.16 \mathrm{E}$ & $E+01$ & $5.75 \mathrm{E}$ & $E+02$ & 6.97E-01 \\
\hline 16 & $1.38 \mathrm{E}+07$ & 1.77E+01 & $2.48 \mathrm{E}-06$ & $1.55 \mathrm{E}+07$ & & 4.07E+08 & & $1.40 \mathrm{E}+05$ & $3.16 \mathrm{E}$ & $E+01$ & $5.76 \mathrm{E}$ & $E+02$ & $6.98 \mathrm{E}-01$ \\
\hline 17 & $1.39 \mathrm{E}+07$ & 1.77E+01 & $2.56 \mathrm{E}-06$ & $1.60 \mathrm{E}+07$ & & 4.07E+08 & & $1.40 \mathrm{E}+05$ & $3.16 \mathrm{E}$ & $E+01$ & $5.76 \mathrm{E}$ & $E+02$ & $6.98 \mathrm{E}-01$ \\
\hline 18 & $1.39 \mathrm{E}+07$ & 1.77E+01 & $2.63 \mathrm{E}-06$ & $1.64 \mathrm{E}+07$ & & $4.07 E+08$ & & $1.40 \mathrm{E}+05$ & $3.17 \mathrm{E}$ & $E+01$ & $5.76 \mathrm{E}$ & $E+02$ & $6.99 \mathrm{E}-01$ \\
\hline 19 & $1.39 E+07$ & 1.77E+01 & 2.69E-06 & $1.68 \mathrm{E}+07$ & & $4.07 E+08$ & & $1.41 \mathrm{E}+05$ & $3.17 \mathrm{E}$ & $E+01$ & $5.77 \mathrm{E}$ & $E+02$ & $6.99 \mathrm{E}-01$ \\
\hline
\end{tabular}

Figure C3. Waste stream output information. 


\begin{tabular}{|c|c|c|c|c|c|c|c|c|}
\hline \multirow[b]{2}{*}{ Iteration } & \multicolumn{8}{|c|}{ LLW-GTCC } \\
\hline & $\begin{array}{l}\text { Heat } \\
\text { (W/yr) }\end{array}$ & $\begin{array}{l}\text { Gamma } \\
\text { (W/yr) }\end{array}$ & $\begin{array}{l}\text { Neutron } \\
\text { (W/yr) }\end{array}$ & $\begin{array}{l}\text { Neutron } \\
\text { (\#/s/yr) }\end{array}$ & $\begin{array}{l}\text { Radiotoxicity } \\
\text { (Sv/yr) at t=0 }\end{array}$ & $\begin{array}{l}\text { kaaıotoxıcıty } \\
\text { (Sv/yr) at } \\
\mathrm{t}=10,000 \mathrm{yr}\end{array}$ & $\begin{array}{l}\text { Mass } \\
\text { (kg/yr) }\end{array}$ & $\begin{array}{l}\text { Volume } \\
\text { (m3/yr) }\end{array}$ \\
\hline 1 & $1.56 \mathrm{E}+08$ & 3.39E-01 & $3.54 \mathrm{E}-05$ & $2.21 \mathrm{E}+08$ & $3.25 \mathrm{E}+07$ & $1.40 \mathrm{E}+06$ & $6.19 E+03$ & $1.91 \mathrm{E}+00$ \\
\hline 2 & $2.74 \mathrm{E}+08$ & $1.31 \mathrm{E}+00$ & 1.12E-04 & $6.97 E+08$ & $7.40 \mathrm{E}+07$ & $2.50 E+06$ & $6.64 E+03$ & $2.05 E+00$ \\
\hline 3 & $3.74 \mathrm{E}+08$ & $1.64 \mathrm{E}+00$ & 1.97E-04 & $1.23 \mathrm{E}+09$ & $1.11 \mathrm{E}+08$ & $3.38 \mathrm{E}+06$ & $6.96 \mathrm{E}+03$ & $2.15 \mathrm{E}+00$ \\
\hline 4 & $4.55 E+08$ & $1.91 \mathrm{E}+00$ & $2.80 \mathrm{E}-04$ & $1.75 E+09$ & $1.42 \mathrm{E}+08$ & $4.06 E+06$ & $7.20 E+03$ & $2.23 E+00$ \\
\hline 5 & $5.21 E+08$ & $2.12 \mathrm{E}+00$ & $3.58 \mathrm{E}-04$ & $2.24 \mathrm{E}+09$ & $1.67 \mathrm{E}+08$ & $4.59 E+06$ & $7.37 \mathrm{E}+03$ & $2.28 \mathrm{E}+00$ \\
\hline 6 & $5.73 E+08$ & $2.28 \mathrm{E}+00$ & 4.30E-04 & $2.69 E+09$ & $1.87 \mathrm{E}+08$ & $5.00 E+06$ & $7.49 E+03$ & $2.32 E+00$ \\
\hline 7 & $6.13 \mathrm{E}+08$ & $2.40 \mathrm{E}+00$ & 4.97E-04 & $3.10 \mathrm{E}+09$ & $2.03 E+08$ & $5.32 E+06$ & $7.59 \mathrm{E}+03$ & $2.35 \mathrm{E}+00$ \\
\hline 8 & $6.44 \mathrm{E}+08$ & $2.50 \mathrm{E}+00$ & $5.60 \mathrm{E}-04$ & $3.49 E+09$ & $2.16 \mathrm{E}+08$ & $5.56 \mathrm{E}+06$ & $7.66 \mathrm{E}+03$ & $2.37 \mathrm{E}+00$ \\
\hline 9 & $6.67 \mathrm{E}+08$ & $2.57 \mathrm{E}+00$ & 6.19E-04 & $3.86 \mathrm{E}+09$ & $2.27 \mathrm{E}+08$ & $5.75 \mathrm{E}+06$ & $7.71 E+03$ & $2.39 E+00$ \\
\hline 10 & $6.86 \mathrm{E}+08$ & $2.63 E+00$ & $6.75 \mathrm{E}-04$ & $4.22 \mathrm{E}+09$ & $2.35 E+08$ & $5.90 \mathrm{E}+06$ & $7.75 E+03$ & $2.40 \mathrm{E}+00$ \\
\hline 11 & $6.99 E+08$ & $2.67 E+00$ & 7.29E-04 & $4.55 E+09$ & $2.42 \mathrm{E}+08$ & $6.01 E+06$ & $7.78 \mathrm{E}+03$ & $2.41 E+00$ \\
\hline 12 & $7.10 \mathrm{E}+08$ & $2.71 \mathrm{E}+00$ & $7.81 \mathrm{E}-04$ & $4.87 E+09$ & $2.47 \mathrm{E}+08$ & $6.10 E+06$ & $7.81 E+03$ & $2.42 \mathrm{E}+00$ \\
\hline 13 & $7.18 \mathrm{E}+08$ & $2.73 E+00$ & 8.29E-04 & $5.18 \mathrm{E}+09$ & $2.52 E+08$ & $6.16 \mathrm{E}+06$ & $7.82 \mathrm{E}+03$ & $2.42 \mathrm{E}+00$ \\
\hline 14 & $7.24 \mathrm{E}+08$ & $2.76 \mathrm{E}+00$ & 8.75E-04 & $5.46 \mathrm{E}+09$ & $2.55 E+08$ & $6.21 \mathrm{E}+06$ & $7.84 \mathrm{E}+03$ & $2.43 \mathrm{E}+00$ \\
\hline 15 & $7.28 \mathrm{E}+08$ & $2.77 \mathrm{E}+00$ & $9.18 \mathrm{E}-04$ & $5.73 E+09$ & $2.58 \mathrm{E}+08$ & $6.25 \mathrm{E}+06$ & $7.85 E+03$ & $2.43 E+00$ \\
\hline 16 & $7.32 E+08$ & $2.78 \mathrm{E}+00$ & $9.58 \mathrm{E}-04$ & $5.98 \mathrm{E}+09$ & $2.60 E+08$ & $6.28 \mathrm{E}+06$ & $7.85 E+03$ & $2.43 E+00$ \\
\hline 17 & $7.34 \mathrm{E}+08$ & $2.79 \mathrm{E}+00$ & 9.95E-04 & $6.21 \mathrm{E}+09$ & $2.62 \mathrm{E}+08$ & $6.31 \mathrm{E}+06$ & $7.86 \mathrm{E}+03$ & $2.43 \mathrm{E}+00$ \\
\hline 18 & $7.37 \mathrm{E}+08$ & $2.80 \mathrm{E}+00$ & $1.03 E-03$ & $6.42 E+09$ & $2.63 E+08$ & $6.33 \mathrm{E}+06$ & $7.87 \mathrm{E}+03$ & $2.44 \mathrm{E}+00$ \\
\hline 19 & $7.38 \mathrm{E}+08$ & $2.81 E+00$ & $1.06 \mathrm{E}-03$ & $6.61 \mathrm{E}+09$ & $2.64 \mathrm{E}+08$ & $6.34 \mathrm{E}+06$ & $7.87 E+03$ & $2.44 \mathrm{E}+00$ \\
\hline
\end{tabular}

\begin{tabular}{|c|c|c|c|c|c|c|c|c|c|}
\hline \multirow[b]{2}{*}{ Iteration } & \multicolumn{9}{|c|}{ Zeolite } \\
\hline & $\begin{array}{l}\text { Heat } \\
(\mathrm{W} / \mathrm{yr})\end{array}$ & $\begin{array}{l}\text { Gamma } \\
\text { (W/yr) }\end{array}$ & $\begin{array}{l}\text { Neutron } \\
\text { (W/yr) }\end{array}$ & $\begin{array}{l}\text { Neutron } \\
(\# / \mathrm{yr})\end{array}$ & $\begin{array}{l}\text { Radiotoxicity } \\
\text { (Sv/yr) at } t=0\end{array}$ & $\begin{array}{l}\text { Radiotoxicity } \\
\text { (Sv/yr) at } \\
t=10,000 y r\end{array}$ & $\begin{array}{l}\text { 10CFR61 } \\
\text { Class C sum }\end{array}$ & $\begin{array}{l}\text { Waste Mass } \\
(\mathrm{kg} / \mathrm{yr})\end{array}$ & $\begin{array}{l}\text { Volume } \\
\text { (m3/yr) }\end{array}$ \\
\hline 1 & 4.95E-04 & $1.59 \mathrm{E}-04$ & $0.00 E+00$ & $0.00 E+00$ & $4.35 \mathrm{E}+03$ & $4.35 \mathrm{E}+03$ & 5.35E-01 & $3.56 \mathrm{E}+02$ & $1.98 \mathrm{E}-01$ \\
\hline 2 & $5.33 \mathrm{E}-04$ & $1.71 \mathrm{E}-04$ & $0.00 E+00$ & $0.00 \mathrm{E}+00$ & $4.69 \mathrm{E}+03$ & $4.69 \mathrm{E}+03$ & $5.76 \mathrm{E}-01$ & $3.92 \mathrm{E}+02$ & $2.18 \mathrm{E}-01$ \\
\hline 3 & $5.60 \mathrm{E}-04$ & $1.80 \mathrm{E}-04$ & $0.00 E+00$ & $0.00 E+00$ & $4.93 E+03$ & $4.92 E+03$ & $6.05 \mathrm{E}-01$ & 4.17E+02 & 2.32E-01 \\
\hline 4 & $5.79 \mathrm{E}-04$ & $1.86 \mathrm{E}-04$ & $0.00 E+00$ & $0.00 E+00$ & $5.10 E+03$ & $5.10 E+03$ & $6.26 \mathrm{E}-01$ & $3.95 \mathrm{E}+02$ & 2.20E-01 \\
\hline 5 & 5.94E-04 & $1.91 \mathrm{E}-04$ & $0.00 E+00$ & $0.00 \mathrm{E}+00$ & $5.22 \mathrm{E}+03$ & $5.22 \mathrm{E}+03$ & $6.42 \mathrm{E}-01$ & $4.05 \mathrm{E}+02$ & 2.25E-01 \\
\hline 6 & $6.04 \mathrm{E}-04$ & $1.94 \mathrm{E}-04$ & $0.00 E+00$ & $0.00 E+00$ & $5.32 E+03$ & $5.32 \mathrm{E}+03$ & $6.53 \mathrm{E}-01$ & $4.12 \mathrm{E}+02$ & 2.29E-01 \\
\hline 7 & $6.12 \mathrm{E}-04$ & 1.97E-04 & $0.00 E+00$ & $0.00 E+00$ & $5.39 E+03$ & $5.39 \mathrm{E}+03$ & $6.62 \mathrm{E}-01$ & 4.17E+02 & 2.32E-01 \\
\hline 8 & $6.18 \mathrm{E}-04$ & $1.98 \mathrm{E}-04$ & $0.00 E+00$ & $0.00 \mathrm{E}+00$ & $5.44 \mathrm{E}+03$ & $5.44 E+03$ & $6.68 \mathrm{E}-01$ & $4.21 \mathrm{E}+02$ & 2.34E-01 \\
\hline 9 & $6.23 \mathrm{E}-04$ & 2.00E-04 & $0.00 E+00$ & $0.00 E+00$ & $5.48 \mathrm{E}+03$ & $5.48 \mathrm{E}+03$ & $6.73 \mathrm{E}-01$ & $4.24 \mathrm{E}+02$ & 2.36E-01 \\
\hline 10 & $6.26 \mathrm{E}-04$ & 2.01E-04 & $0.00 E+00$ & $0.00 E+00$ & $5.51 E+03$ & $5.51 E+03$ & 6.77E-01 & $4.26 \mathrm{E}+02$ & 2.37E-01 \\
\hline 11 & $6.29 \mathrm{E}-04$ & $2.02 \mathrm{E}-04$ & $0.00 \mathrm{E}+00$ & $0.00 \mathrm{E}+00$ & $5.53 E+03$ & $5.53 E+03$ & $6.79 \mathrm{E}-01$ & $4.28 \mathrm{E}+02$ & $2.38 \mathrm{E}-01$ \\
\hline 12 & 6.31E-04 & $2.02 \mathrm{E}-04$ & $0.00 E+00$ & $0.00 \mathrm{E}+00$ & $5.55 \mathrm{E}+03$ & $5.55 \mathrm{E}+03$ & $6.82 \mathrm{E}-01$ & $4.29 \mathrm{E}+02$ & $2.38 \mathrm{E}-01$ \\
\hline 13 & 0.00063204 & 0.000202883 & 0 & 0 & 5560.445294 & 5557.99095 & $6.83 \mathrm{E}-01$ & 4.30E+02 & $2.39 \mathrm{E}-01$ \\
\hline 14 & 0.00063316 & 0.000203243 & 0 & 0 & 5570.30467 & 5567.845975 & $6.84 \mathrm{E}-01$ & $4.31 E+02$ & 2.39E-01 \\
\hline 15 & 0.00063398 & 0.000203506 & 0 & 0 & 5577.524529 & 5575.062647 & $6.85 \mathrm{E}-01$ & $4.31 E+02$ & 2.40E-01 \\
\hline 16 & 0.00063464 & 0.000203718 & 0 & 0 & 5583.322893 & 5580.858451 & $6.86 \mathrm{E}-01$ & $4.32 E+02$ & 2.40E-01 \\
\hline 17 & 0.00063519 & 0.000203895 & 0 & 0 & 5588.174954 & 5585.70837 & $6.87 \mathrm{E}-01$ & $4.32 \mathrm{E}+02$ & $2.40 \mathrm{E}-01$ \\
\hline 18 & 0.00063562 & 0.000204033 & 0 & 0 & 5591.957301 & 5589.489049 & 6.87E-01 & $4.32 \mathrm{E}+02$ & 2.40E-01 \\
\hline 19 & 0.00063594 & 0.000204136 & 0 & 0 & 5594.786089 & 5592.316588 & 6.87E-01 & 4.33E+02 & 2.40E-01 \\
\hline
\end{tabular}

Figure C3. Waste stream output information (continued). 
The FIT 2 Model

May 13, 2011

\begin{tabular}{|c|c|c|c|c|c|c|c|c|c|}
\hline \multirow[b]{2}{*}{ Iteration } & \multicolumn{9}{|c|}{$\mathrm{Kr}-\mathrm{Xe}$} \\
\hline & Heat (W/yr) & $\begin{array}{l}\text { Gamma } \\
(W / y r)\end{array}$ & $\begin{array}{l}\text { Neutron } \\
\text { (W/yr) }\end{array}$ & Neutron (\#/yr) & $\begin{array}{l}\text { Radiotoxicity } \\
\text { (Sv/yr) at t=0 }\end{array}$ & $\begin{array}{l}\text { Radiotoxicity } \\
\text { (Sv/yr) at } \\
\mathrm{t}=10,000 \mathrm{yr}\end{array}$ & $\begin{array}{l}\text { 10CFR61 } \\
\text { Class C } \\
\text { sum }\end{array}$ & $\begin{array}{l}\text { Waste } \\
\text { Mass } \\
(\mathrm{kg} / \mathrm{yr}) \\
\end{array}$ & $\begin{array}{l}\text { Volume } \\
(\mathrm{m} 3 / \mathrm{yr})\end{array}$ \\
\hline 1 & $3.31 \mathrm{E}+02$ & $1.38 \mathrm{E}+01$ & $0.00 \mathrm{E}+00$ & $0.00 \mathrm{E}+00$ & $0.00 \mathrm{E}+00$ & $0.00 E+00$ & 9.75E-07 & $1.81 \mathrm{E}+02$ & $9.61 \mathrm{E}-01$ \\
\hline 2 & $3.50 E+02$ & $1.46 \mathrm{E}+01$ & $0.00 \mathrm{E}+00$ & $0.00 E+00$ & $0.00 E+00$ & $0.00 E+00$ & 1.25E-06 & $1.91 \mathrm{E}+02$ & $1.01 \mathrm{E}+00$ \\
\hline 3 & $3.64 E+02$ & $1.52 \mathrm{E}+01$ & $0.00 E+00$ & $0.00 E+00$ & $0.00 E+00$ & $0.00 E+00$ & 1.43E-06 & $1.98 \mathrm{E}+02$ & $1.05 \mathrm{E}+00$ \\
\hline 4 & $3.73 E+02$ & $1.56 \mathrm{E}+01$ & $0.00 E+00$ & $0.00 \mathrm{E}+00$ & $0.00 E+00$ & $0.00 \mathrm{E}+00$ & 1.57E-06 & $2.03 E+02$ & $1.08 \mathrm{E}+00$ \\
\hline 5 & $3.81 E+02$ & $1.59 \mathrm{E}+01$ & $0.00 \mathrm{E}+00$ & $0.00 \mathrm{E}+00$ & $0.00 \mathrm{E}+00$ & $0.00 \mathrm{E}+00$ & 1.67E-06 & $2.07 \mathrm{E}+02$ & 1. $10 \mathrm{E}+00$ \\
\hline 6 & $3.86 \mathrm{E}+02$ & $1.61 \mathrm{E}+01$ & $0.00 \mathrm{E}+00$ & $0.00 \mathrm{E}+00$ & $0.00 \mathrm{E}+00$ & $0.00 \mathrm{E}+00$ & $1.74 \mathrm{E}-06$ & $2.09 \mathrm{E}+02$ & $1.11 \mathrm{E}+00$ \\
\hline 7 & $3.90 \mathrm{E}+02$ & 1.63E+01 & $0.00 E+00$ & $0.00 E+00$ & $0.00 E+00$ & $0.00 E+00$ & 1.79E-06 & $2.11 E+02$ & $1.12 \mathrm{E}+00$ \\
\hline 8 & $3.93 \mathrm{E}+02$ & $1.64 \mathrm{E}+01$ & $0.00 E+00$ & $0.00 E+00$ & $0.00 \mathrm{E}+00$ & $0.00 E+00$ & $1.83 \mathrm{E}-06$ & $2.13 E+02$ & 1.13E+00 \\
\hline 9 & $3.95 \mathrm{E}+02$ & $1.65 \mathrm{E}+01$ & $0.00 E+00$ & $0.00 E+00$ & $0.00 E+00$ & $0.00 E+00$ & $1.86 \mathrm{E}-06$ & $2.14 \mathrm{E}+02$ & $1.14 \mathrm{E}+00$ \\
\hline 10 & $3.97 \mathrm{E}+02$ & $1.65 \mathrm{E}+01$ & $0.00 \mathrm{E}+00$ & $0.00 \mathrm{E}+00$ & $0.00 \mathrm{E}+00$ & $0.00 \mathrm{E}+00$ & 1.89E-06 & $2.15 \mathrm{E}+02$ & $1.14 \mathrm{E}+00$ \\
\hline 11 & $3.98 \mathrm{E}+02$ & $1.66 \mathrm{E}+01$ & $0.00 E+00$ & $0.00 E+00$ & $0.00 E+00$ & $0.00 E+00$ & $1.91 \mathrm{E}-06$ & $2.16 \mathrm{E}+02$ & $1.15 E+00$ \\
\hline 12 & $3.99 \mathrm{E}+02$ & $1.66 \mathrm{E}+01$ & $0.00 E+00$ & $0.00 E+00$ & $0.00 E+00$ & $0.00 E+00$ & $1.92 \mathrm{E}-06$ & $2.16 \mathrm{E}+02$ & $1.15 E+00$ \\
\hline 13 & $4.00 E+02$ & $1.67 \mathrm{E}+01$ & $0.00 \mathrm{E}+00$ & $0.00 E+00$ & $0.00 \mathrm{E}+00$ & $0.00 \mathrm{E}+00$ & 1.93E-06 & $2.17 \mathrm{E}+02$ & 1.15E+0C \\
\hline 14 & $4.00 E+02$ & $1.67 \mathrm{E}+01$ & $0.00 E+00$ & $0.00 E+00$ & $0.00 E+00$ & $0.00 E+00$ & $1.94 \mathrm{E}-06$ & $2.17 E+02$ & $1.15 \mathrm{E}+00$ \\
\hline 15 & $4.01 E+02$ & $1.67 \mathrm{E}+01$ & $0.00 \mathrm{E}+00$ & $0.00 E+00$ & $0.00 E+00$ & $0.00 E+00$ & 1.95E-06 & $2.17 E+02$ & $1.15 \mathrm{E}+00$ \\
\hline 16 & $4.01 E+02$ & $1.67 \mathrm{E}+01$ & $0.00 \mathrm{E}+00$ & $0.00 E+00$ & $0.00 E+00$ & $0.00 \mathrm{E}+00$ & 1.95E-06 & $2.17 E+02$ & $1.15 \mathrm{E}+00$ \\
\hline 17 & $4.01 E+02$ & $1.67 \mathrm{E}+01$ & $0.00 \mathrm{E}+00$ & $0.00 \mathrm{E}+00$ & $0.00 \mathrm{E}+00$ & $0.00 \mathrm{E}+00$ & 1.96E-06 & $2.17 E+02$ & 1.15E+00 \\
\hline 18 & $4.01 E+02$ & $1.67 \mathrm{E}+01$ & $0.00 \mathrm{E}+00$ & $0.00 \mathrm{E}+00$ & $0.00 \mathrm{E}+00$ & $0.00 \mathrm{E}+00$ & 1.96E-06 & $2.18 \mathrm{E}+02$ & 1.16E+00 \\
\hline 19 & $4.02 E+02$ & $1.67 \mathrm{E}+01$ & $0.00 E+00$ & $0.00 E+00$ & $0.00 E+00$ & $0.00 E+00$ & 1.96E-06 & $2.18 \mathrm{E}+02$ & $1.16 \mathrm{E}+00$ \\
\hline
\end{tabular}

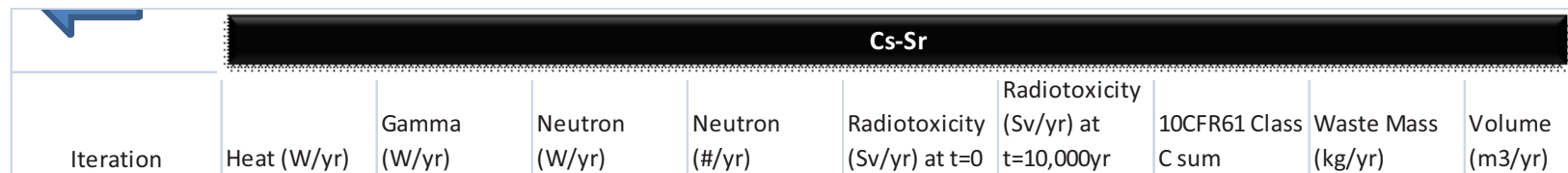

\begin{tabular}{|c|c|c|c|c|c|c|c|c|c|}
\hline 1 & $5.97 E+06$ & $1.72 E+04$ & $2.58 \mathrm{E}-06$ & $1.61 \mathrm{E}+07$ & $4.88 E+09$ & $5.51 E+04$ & $8.15 E+01$ & $4.56 \mathrm{E}+02$ & 5.52E-01 \\
\hline 2 & $8.15 E+06$ & $1.91 E+04$ & $4.56 \mathrm{E}-06$ & $2.84 E+07$ & $5.23 E+09$ & $7.45 E+04$ & $8.76 E+01$ & $4.88 \mathrm{E}+02$ & $5.92 \mathrm{E}-01$ \\
\hline 3 & $9.96 E+06$ & $2.04 E+04$ & $6.48 \mathrm{E}-06$ & $4.05 E+07$ & $5.47 E+09$ & $8.97 E+04$ & $9.20 E+01$ & $5.11 E+02$ & $6.20 \mathrm{E}-01$ \\
\hline 4 & $1.14 \mathrm{E}+07$ & $2.13 E+04$ & $8.28 \mathrm{E}-06$ & $5.17 \mathrm{E}+07$ & $5.65 E+09$ & $1.01 E+05$ & $9.52 E+01$ & $5.28 \mathrm{E}+02$ & $6.40 \mathrm{E}-01$ \\
\hline 5 & $1.25 \mathrm{E}+07$ & $2.20 E+04$ & $9.94 \mathrm{E}-06$ & $6.20 E+07$ & $5.78 E+09$ & $1.11 \mathrm{E}+05$ & $9.76 \mathrm{E}+01$ & $5.40 E+02$ & $6.55 \mathrm{E}-01$ \\
\hline 6 & $1.34 \mathrm{E}+07$ & $2.25 E+04$ & 1.15E-05 & $7.17 E+07$ & $5.88 E+09$ & $1.18 \mathrm{E}+05$ & $9.94 \mathrm{E}+01$ & $5.49 \mathrm{E}+02$ & $6.66 \mathrm{E}-01$ \\
\hline 7 & $1.41 E+07$ & $2.29 E+04$ & 1.30E-05 & $8.08 \mathrm{E}+07$ & $5.95 E+09$ & $1.23 E+05$ & $1.01 E+02$ & $5.56 \mathrm{E}+02$ & $6.74 \mathrm{E}-01$ \\
\hline 8 & $1.46 \mathrm{E}+07$ & $2.32 E+04$ & $1.43 \mathrm{E}-05$ & $8.96 \mathrm{E}+07$ & $6.01 E+09$ & $1.27 \mathrm{E}+05$ & $1.02 E+02$ & $5.61 E+02$ & $6.81 \mathrm{E}-01$ \\
\hline 9 & $1.50 \mathrm{E}+07$ & $2.34 \mathrm{E}+04$ & 1.57E-05 & $9.79 \mathrm{E}+07$ & $6.05 E+09$ & $1.31 \mathrm{E}+05$ & $1.03 E+02$ & $5.65 \mathrm{E}+02$ & $6.85 \mathrm{E}-01$ \\
\hline 10 & $1.53 E+07$ & $2.36 E+04$ & 1.70E-05 & $1.06 \mathrm{E}+08$ & $6.08 E+09$ & $1.33 \mathrm{E}+05$ & $1.03 E+02$ & $5.68 \mathrm{E}+02$ & $6.89 \mathrm{E}-01$ \\
\hline 11 & $1.56 \mathrm{E}+07$ & $2.37 E+04$ & 1.82E-05 & $1.14 \mathrm{E}+08$ & $6.10 E+09$ & $1.35 \mathrm{E}+05$ & $1.04 \mathrm{E}+02$ & $5.70 \mathrm{E}+02$ & 6.91E-01 \\
\hline 12 & $1.57 \mathrm{E}+07$ & $2.38 \mathrm{E}+04$ & 1.94E-05 & $1.21 \mathrm{E}+08$ & $6.12 E+09$ & $1.36 \mathrm{E}+05$ & $1.04 \mathrm{E}+02$ & $5.72 \mathrm{E}+02$ & 6.93E-01 \\
\hline 13 & $1.59 \mathrm{E}+07$ & $2.39 E+04$ & $2.06 \mathrm{E}-05$ & $1.28 \mathrm{E}+08$ & $6.14 \mathrm{E}+09$ & $1.37 \mathrm{E}+05$ & $1.04 \mathrm{E}+02$ & $5.73 \mathrm{E}+02$ & $6.95 \mathrm{E}-01$ \\
\hline 14 & $1.60 \mathrm{E}+07$ & $2.39 E+04$ & 2.16E-05 & $1.35 \mathrm{E}+08$ & $6.15 E+09$ & $1.38 \mathrm{E}+05$ & $1.04 \mathrm{E}+02$ & $5.74 \mathrm{E}+02$ & 6.96E-01 \\
\hline 15 & $1.60 \mathrm{E}+07$ & $2.40 E+04$ & $2.26 \mathrm{E}-05$ & $1.41 \mathrm{E}+08$ & $6.15 E+09$ & $1.39 E+05$ & $1.05 E+02$ & $5.75 \mathrm{E}+02$ & 6.97E-01 \\
\hline 16 & $1.61 E+07$ & $2.40 E+04$ & $2.36 \mathrm{E}-05$ & $1.47 \mathrm{E}+08$ & $6.16 \mathrm{E}+09$ & $1.40 \mathrm{E}+05$ & $1.05 E+02$ & $5.76 \mathrm{E}+02$ & $6.98 \mathrm{E}-01$ \\
\hline 17 & $1.62 E+07$ & $2.40 E+04$ & $2.44 \mathrm{E}-05$ & $1.52 \mathrm{E}+08$ & $6.16 \mathrm{E}+09$ & $1.40 \mathrm{E}+05$ & $1.05 E+02$ & $5.76 \mathrm{E}+02$ & $6.98 \mathrm{E}-01$ \\
\hline 18 & $1.62 \mathrm{E}+07$ & $2.40 E+04$ & $2.52 \mathrm{E}-05$ & $1.57 \mathrm{E}+08$ & $6.17 E+09$ & $1.40 \mathrm{E}+05$ & $1.05 E+02$ & $5.76 \mathrm{E}+02$ & 6.99E-01 \\
\hline 19 & $1.62 E+07$ & $2.40 E+04$ & 2.59E-05 & $1.62 E+08$ & $6.17 E+09$ & $1.41 E+05$ & $1.05 E+02$ & $5.77 \mathrm{E}+02$ & 6.99E-01 \\
\hline
\end{tabular}

Figure C3. Waste stream output information (continued). 


\begin{tabular}{|c|c|c|c|c|c|c|c|c|c|}
\hline \multirow[b]{2}{*}{ Iteration } & \multicolumn{9}{|c|}{ Metal Alloy Ingot } \\
\hline & Heat (W/yr) & Gamma (W/yr) & Neutron (W/yr) & Neutron (\#/yr) & $\begin{array}{l}\text { Radiotoxicity } \\
(\mathrm{Sv} / \mathrm{yr}) \text { at } \mathrm{t}=0\end{array}$ & $\begin{array}{l}\text { Radiotoxicity } \\
\text { (Sv/yr) at } \\
\mathrm{t}=10,000 \mathrm{yr}\end{array}$ & $\begin{array}{l}\text { 10CFR61 Class C } \\
\text { sum }\end{array}$ & $\begin{array}{l}\text { Waste Mass } \\
(\mathrm{kg} / \mathrm{yr})\end{array}$ & Volume (m3/yr) \\
\hline 1 & $2.00 \mathrm{E}+08$ & $2.04 \mathrm{E}+02$ & $8.70 \mathrm{E}-05$ & $5.43 \mathrm{E}+08$ & $1.13 \mathrm{E}+08$ & $1.82 \mathrm{E}+06$ & $6.94 \mathrm{E}+03$ & $4.84 \mathrm{E}+02$ & $5.80 \mathrm{E}-02$ \\
\hline 2 & $2.74 \mathrm{E}+08$ & $2.28 \mathrm{E}+02$ & $1.54 \mathrm{E}-04$ & $9.59 E+08$ & $1.48 \mathrm{E}+08$ & $2.46 \mathrm{E}+06$ & $7.50 \mathrm{E}+03$ & $5.22 \mathrm{E}+02$ & $6.30 \mathrm{E}-02$ \\
\hline 3 & $3.34 E+08$ & $2.46 \mathrm{E}+02$ & $2.18 \mathrm{E}-04$ & $1.36 \mathrm{E}+09$ & $1.77 \mathrm{E}+08$ & $2.96 \mathrm{E}+06$ & $7.89 E+03$ & $5.49 \mathrm{E}+02$ & $6.66 \mathrm{E}-02$ \\
\hline 4 & $3.83 E+08$ & $2.58 E+02$ & 2.79E-04 & $1.74 E+09$ & $1.99 \mathrm{E}+08$ & $3.36 \mathrm{E}+06$ & $8.18 E+03$ & $5.68 \mathrm{E}+02$ & $6.92 \mathrm{E}-02$ \\
\hline 5 & $4.21 E+08$ & $2.67 \mathrm{E}+02$ & 3.35E-04 & $2.09 E+09$ & $2.18 \mathrm{E}+08$ & $3.66 \mathrm{E}+06$ & $8.39 E+03$ & $5.83 E+02$ & 7.11E-02 \\
\hline 6 & $4.51 E+08$ & $2.74 \mathrm{E}+02$ & 3.87E-04 & $2.42 E+09$ & $2.32 E+08$ & $3.90 E+06$ & $8.55 \mathrm{E}+03$ & $5.93 E+02$ & 7.25E-02 \\
\hline 7 & 4.74E+08 & $2.79 \mathrm{E}+02$ & $4.36 \mathrm{E}-04$ & $2.72 E+09$ & $2.43 E+08$ & $4.08 \mathrm{E}+06$ & $8.67 E+03$ & $6.01 \mathrm{E}+02$ & 7.35E-02 \\
\hline 8 & $4.91 E+08$ & $2.83 \mathrm{E}+02$ & 4.84E-04 & $3.02 E+09$ & $2.53 E+08$ & 4.22E+06 & $8.75 \mathrm{E}+03$ & $6.07 \mathrm{E}+02$ & 7.43E-02 \\
\hline 9 & $5.05 E+08$ & $2.86 \mathrm{E}+02$ & $5.29 \mathrm{E}-04$ & $3.30 E+09$ & $2.60 E+08$ & $4.32 E+06$ & $8.82 E+03$ & $6.12 E+02$ & 7.49E-02 \\
\hline 10 & $5.15 E+08$ & $2.88 \mathrm{E}+02$ & $5.72 \mathrm{E}-04$ & $3.57 E+09$ & $2.66 \mathrm{E}+08$ & $4.41 E+06$ & $8.87 E+03$ & $6.15 E+02$ & 7.53E-02 \\
\hline 11 & $5.23 E+08$ & $2.89 E+02$ & $6.14 \mathrm{E}-04$ & $3.83 E+09$ & $2.71 E+08$ & $4.47 E+06$ & $8.91 E+03$ & $6.18 \mathrm{E}+02$ & 7.57E-02 \\
\hline 12 & $5.29 \mathrm{E}+08$ & $2.91 \mathrm{E}+02$ & $6.55 \mathrm{E}-04$ & $4.09 E+09$ & $2.74 \mathrm{E}+08$ & $4.52 E+06$ & $8.93 \mathrm{E}+03$ & $6.19 \mathrm{E}+02$ & 7.59E-02 \\
\hline 13 & $5.33 \mathrm{E}+08$ & $2.92 \mathrm{E}+02$ & $6.93 \mathrm{E}-04$ & $4.32 E+09$ & $2.77 \mathrm{E}+08$ & $4.56 \mathrm{E}+06$ & $8.96 \mathrm{E}+03$ & $6.21 \mathrm{E}+02$ & $7.61 \mathrm{E}-02$ \\
\hline 14 & $5.36 E+08$ & $2.92 \mathrm{E}+02$ & $7.29 \mathrm{E}-04$ & $4.55 E+09$ & $2.80 E+08$ & $4.59 \mathrm{E}+06$ & $8.97 E+03$ & $6.22 E+02$ & 7.63E-02 \\
\hline 15 & $5.39 \mathrm{E}+08$ & $2.93 \mathrm{E}+02$ & 7.63E-04 & $4.76 \mathrm{E}+09$ & $2.81 \mathrm{E}+08$ & $4.61 E+06$ & $8.99 E+03$ & $6.23 E+02$ & 7.64E-02 \\
\hline 16 & $5.41 E+08$ & $2.93 \mathrm{E}+02$ & 7.94E-04 & $4.96 \mathrm{E}+09$ & $2.83 E+08$ & 4. $63 E+06$ & $9.00 E+03$ & $6.24 \mathrm{E}+02$ & 7.64E-02 \\
\hline 17 & $5.43 E+08$ & $2.94 \mathrm{E}+02$ & 8.23E-04 & $5.14 \mathrm{E}+09$ & $2.84 \mathrm{E}+08$ & 4.64E+06 & $9.00 \mathrm{E}+03$ & $6.24 \mathrm{E}+02$ & 7.65E-02 \\
\hline 18 & $5.44 \mathrm{E}+08$ & $2.94 \mathrm{E}+02$ & $8.49 \mathrm{E}-04$ & $5.30 \mathrm{E}+09$ & $2.85 E+08$ & 4.65E+06 & $9.01 E+03$ & $6.24 \mathrm{E}+02$ & 7.66E-02 \\
\hline 19 & $5.45 E+08$ & $2.94 \mathrm{E}+02$ & 8.73E-04 & $5.45 E+09$ & $2.86 \mathrm{E}+08$ & 4.66E+06 & $9.02 E+03$ & $6.25 E+02$ & 7.66E-02 \\
\hline
\end{tabular}

\begin{tabular}{|c|c|c|c|c|c|c|c|c|c|}
\hline \multirow[b]{2}{*}{ Iteration } & \multicolumn{9}{|c|}{ Remainder Metal } \\
\hline & Heat (W/yr) & Gamma (W/yr) & $\begin{array}{l}\text { Neutron } \\
\text { (W/yr) }\end{array}$ & Neutron (\#/yr) & $\begin{array}{l}\text { Radiotoxicity } \\
\text { (Sv/yr) at } t=0\end{array}$ & $\begin{array}{l}\text { Radiotoxicity } \\
\text { (Sv/yr) at } \\
\mathrm{t}=10,000 \mathrm{yr}\end{array}$ & $\begin{array}{l}\text { 10CFR61 Class } \\
\text { C sum }\end{array}$ & $\begin{array}{l}\text { Waste Mass } \\
(\mathrm{kg} / \mathrm{yr})\end{array}$ & $\begin{array}{l}\text { Volume } \\
\text { (m3/yr) }\end{array}$ \\
\hline 1 & $0.00 E+00$ & $0.00 E+00$ & $0.00 \mathrm{E}+00$ & $0.00 E+00$ & $0.00 E+00$ & $0.00 E+00$ & $0.00 E+00$ & $6.16 \mathrm{E}+03$ & $1.89 \mathrm{E}+00$ \\
\hline 2 & $0.00 \mathrm{E}+00$ & $0.00 E+00$ & $0.00 E+00$ & $0.00 E+00$ & $0.00 E+00$ & $0.00 E+00$ & $0.00 E+00$ & $6.60 E+03$ & $2.02 \mathrm{E}+00$ \\
\hline 3 & $0.00 E+00$ & $0.00 E+00$ & $0.00 E+00$ & $0.00 \mathrm{E}+00$ & $0.00 E+00$ & $0.00 E+00$ & $0.00 E+00$ & $6.91 E+03$ & $2.12 \mathrm{E}+00$ \\
\hline 4 & $0.00 E+00$ & $0.00 E+00$ & $0.00 E+00$ & $0.00 \mathrm{E}+00$ & $0.00 E+00$ & $0.00 E+00$ & $0.00 E+00$ & $7.14 \mathrm{E}+03$ & $2.19 \mathrm{E}+00$ \\
\hline 5 & $0.00 \mathrm{E}+00$ & $0.00 \mathrm{E}+00$ & $0.00 \mathrm{E}+00$ & $0.00 \mathrm{E}+00$ & $0.00 E+00$ & $0.00 \mathrm{E}+00$ & $0.00 \mathrm{E}+00$ & $7.30 \mathrm{E}+03$ & $2.24 \mathrm{E}+00$ \\
\hline 6 & $0.00 E+00$ & $0.00 E+00$ & $0.00 E+00$ & $0.00 \mathrm{E}+00$ & $0.00 E+00$ & $0.00 \mathrm{E}+00$ & $0.00 E+00$ & $7.43 E+03$ & $2.28 \mathrm{E}+00$ \\
\hline 7 & $0.00 E+00$ & $0.00 E+00$ & $0.00 \mathrm{E}+00$ & $0.00 E+00$ & $0.00 E+00$ & $0.00 E+00$ & $0.00 E+00$ & $7.52 E+03$ & $2.31 E+00$ \\
\hline 8 & $0.00 E+00$ & $0.00 \mathrm{E}+00$ & $0.00 E+00$ & $0.00 E+00$ & $0.00 E+00$ & $0.00 E+00$ & $0.00 E+00$ & $7.59 E+03$ & $2.33 \mathrm{E}+00$ \\
\hline 9 & $0.00 E+00$ & $0.00 E+00$ & $0.00 E+00$ & $0.00 E+00$ & $0.00 E+00$ & $0.00 E+00$ & $0.00 E+00$ & $7.64 E+03$ & $2.34 \mathrm{E}+00$ \\
\hline 10 & $0.00 \mathrm{E}+00$ & $0.00 \mathrm{E}+00$ & $0.00 \mathrm{E}+00$ & $0.00 E+00$ & $0.00 E+00$ & $0.00 \mathrm{E}+00$ & $0.00 \mathrm{E}+00$ & $7.68 \mathrm{E}+03$ & $2.35 \mathrm{E}+00$ \\
\hline 11 & $0.00 \mathrm{E}+00$ & $0.00 \mathrm{E}+00$ & $0.00 E+00$ & $0.00 E+00$ & $0.00 E+00$ & $0.00 E+00$ & $0.00 E+00$ & $7.70 E+03$ & $2.36 \mathrm{E}+00$ \\
\hline 12 & $0.00 E+00$ & $0.00 E+00$ & $0.00 E+00$ & $0.00 E+00$ & $0.00 E+00$ & $0.00 E+00$ & $0.00 E+00$ & $7.73 E+03$ & $2.37 E+00$ \\
\hline 13 & $0.00 \mathrm{E}+00$ & $0.00 E+00$ & $0.00 \mathrm{E}+00$ & $0.00 E+00$ & $0.00 E+00$ & $0.00 \mathrm{E}+00$ & $0.00 E+00$ & $7.74 \mathrm{E}+03$ & $2.38 \mathrm{E}+00$ \\
\hline 14 & $0.00 E+00$ & $0.00 E+00$ & $0.00 E+00$ & $0.00 E+00$ & $0.00 E+00$ & $0.00 E+00$ & $0.00 E+00$ & $7.76 \mathrm{E}+03$ & $2.38 \mathrm{E}+00$ \\
\hline 15 & $0.00 \mathrm{E}+00$ & $0.00 \mathrm{E}+00$ & $0.00 \mathrm{E}+00$ & $0.00 \mathrm{E}+00$ & $0.00 \mathrm{E}+00$ & $0.00 \mathrm{E}+00$ & $0.00 \mathrm{E}+00$ & 7.77E+03 & $2.38 \mathrm{E}+00$ \\
\hline 16 & $0.00 E+00$ & $0.00 E+00$ & $0.00 E+00$ & $0.00 E+00$ & $0.00 E+00$ & $0.00 \mathrm{E}+00$ & $0.00 E+00$ & $7.77 \mathrm{E}+03$ & $2.38 \mathrm{E}+00$ \\
\hline 17 & $0.00 \mathrm{E}+00$ & $0.00 \mathrm{E}+00$ & $0.00 \mathrm{E}+00$ & $0.00 \mathrm{E}+00$ & $0.00 \mathrm{E}+00$ & $0.00 \mathrm{E}+00$ & $0.00 \mathrm{E}+00$ & $7.78 \mathrm{E}+03$ & $2.39 \mathrm{E}+00$ \\
\hline 18 & $0.00 E+00$ & $0.00 \mathrm{E}+00$ & $0.00 \mathrm{E}+00$ & $0.00 \mathrm{E}+00$ & $0.00 E+00$ & $0.00 \mathrm{E}+00$ & $0.00 \mathrm{E}+00$ & $7.78 \mathrm{E}+03$ & $2.39 \mathrm{E}+00$ \\
\hline 19 & $0.00 E+00$ & $0.00 E+00$ & $0.00 \mathrm{E}+00$ & $0.00 E+00$ & $0.00 E+00$ & $0.00 E+00$ & $0.00 E+00$ & $7.79 E+03$ & $2.39 E+00$ \\
\hline
\end{tabular}

Figure C3. Waste stream output information (continued). 
The FIT 2 Model

May 13, 2011

\begin{tabular}{|c|c|c|c|c|c|c|c|c|c|}
\hline \multirow[b]{2}{*}{ Iteration } & \multicolumn{9}{|c|}{ HTO Grout } \\
\hline & Heat (W/yr) & Gamma (W/yr) & $\begin{array}{l}\text { Neutron } \\
\text { (W/yr) }\end{array}$ & Neutron (\#/yr) & $\begin{array}{l}\text { Radiotoxicity } \\
\text { (Sv/yr) at } t=0\end{array}$ & $\begin{array}{l}\text { Radiotoxicity } \\
\text { (Sv/yr) at } \\
\mathrm{t}=10,000 \mathrm{yr}\end{array}$ & $\begin{array}{l}\text { 10CFR61 Class } \\
\text { C sum }\end{array}$ & $\begin{array}{l}\text { Waste Mass } \\
(\mathrm{kg} / \mathrm{yr})\end{array}$ & $\begin{array}{l}\text { Volume } \\
\text { (m3/yr) }\end{array}$ \\
\hline 1 & 5.25E-01 & $3.40 \mathrm{E}-04$ & $0.00 \mathrm{E}+00$ & $0.00 \mathrm{E}+00$ & $2.42 E+04$ & 2.93E-92 & $1.62 \mathrm{E}-53$ & $1.53 \mathrm{E}+00$ & 6.63E-04 \\
\hline 2 & 5.87E-01 & 3.80E-04 & $0.00 E+00$ & $0.00 E+00$ & 2.71E+04 & $3.28 \mathrm{E}-92$ & $1.81 E-53$ & 1. $70 \mathrm{E}+00$ & 7.41E-04 \\
\hline 3 & $6.31 \mathrm{E}-01$ & 4.09E-04 & $0.00 E+00$ & $0.00 E+00$ & $2.91 E+04$ & $3.52 \mathrm{E}-92$ & $1.94 \mathrm{E}-53$ & $1.83 \mathrm{E}+00$ & 7.96E-04 \\
\hline 4 & 6.63E-01 & 4.29E-04 & $0.00 \mathrm{E}+00$ & $0.00 \mathrm{E}+00$ & $3.06 \mathrm{E}+04$ & 3.70E-92 & 2.04E-53 & $1.92 \mathrm{E}+00$ & 8.37E-04 \\
\hline 5 & $6.86 \mathrm{E}-01$ & 4.44E-04 & $0.00 \mathrm{E}+00$ & $0.00 \mathrm{E}+00$ & $3.17 E+04$ & $3.83 E-92$ & $2.11 \mathrm{E}-53$ & $1.99 \mathrm{E}+00$ & 8.66E-04 \\
\hline 6 & 7.03E-01 & $4.56 \mathrm{E}-04$ & $0.00 \mathrm{E}+00$ & $0.00 \mathrm{E}+00$ & $3.25 E+04$ & 3.93E-92 & 2.17E-53 & $2.04 \mathrm{E}+00$ & $8.88 \mathrm{E}-04$ \\
\hline 7 & 7.16E-01 & 4.64E-04 & $0.00 E+00$ & $0.00 E+00$ & $3.31 E+04$ & 4.00E-92 & $2.20 \mathrm{E}-53$ & $2.08 \mathrm{E}+00$ & $9.04 \mathrm{E}-04$ \\
\hline 8 & 7.26E-01 & 4.70E-04 & $0.00 E+00$ & $0.00 E+00$ & 3. $35 E+04$ & 4.05E-92 & $2.23 \mathrm{E}-53$ & $2.11 E+00$ & 9.16E-04 \\
\hline 9 & 7.33E-01 & 4.75E-04 & $0.00 \mathrm{E}+00$ & $0.00 E+00$ & $3.38 \mathrm{E}+04$ & 4.10E-92 & $2.26 \mathrm{E}-53$ & $2.13 E+00$ & $9.26 \mathrm{E}-04$ \\
\hline 10 & 7.39E-01 & 4.78E-04 & $0.00 \mathrm{E}+00$ & $0.00 E+00$ & $3.41 E+04$ & 4.13E-92 & 2.27E-53 & $2.14 \mathrm{E}+00$ & $9.32 \mathrm{E}-04$ \\
\hline 11 & 7.43E-01 & 4.81E-04 & $0.00 \mathrm{E}+00$ & $0.00 \mathrm{E}+00$ & $3.43 E+04$ & 4.15E-92 & $2.29 \mathrm{E}-53$ & $2.16 \mathrm{E}+00$ & $9.38 \mathrm{E}-04$ \\
\hline 12 & 7.46E-01 & 4.83E-04 & $0.00 \mathrm{E}+00$ & $0.00 \mathrm{E}+00$ & $3.44 E+04$ & 4.17E-92 & $2.30 \mathrm{E}-53$ & $2.17 \mathrm{E}+00$ & $9.41 \mathrm{E}-04$ \\
\hline 13 & 7.48E-01 & $4.85 \mathrm{E}-04$ & $0.00 \mathrm{E}+00$ & $0.00 \mathrm{E}+00$ & $3.45 E+04$ & 4.18E-92 & $2.30 \mathrm{E}-53$ & 2.17E+00 & $9.44 \mathrm{E}-04$ \\
\hline 14 & $7.50 \mathrm{E}-01$ & 4.86E-04 & $0.00 E+00$ & $0.00 E+00$ & $3.46 E+04$ & 4.19E-92 & $2.31 E-53$ & $2.18 \mathrm{E}+00$ & 9.47E-04 \\
\hline 15 & $7.51 \mathrm{E}-01$ & 4.87E-04 & $0.00 E+00$ & $0.00 E+00$ & $3.47 E+04$ & 4.20E-92 & $2.31 E-53$ & $2.18 \mathrm{E}+00$ & $9.48 \mathrm{E}-04$ \\
\hline 16 & $7.52 \mathrm{E}-01$ & 4.87E-04 & $0.00 E+00$ & $0.00 E+00$ & $3.47 E+04$ & 4.20E-92 & $2.32 E-53$ & $2.18 \mathrm{E}+00$ & $9.50 \mathrm{E}-04$ \\
\hline 17 & 7.53E-01 & $4.88 \mathrm{E}-04$ & $0.00 E+00$ & $0.00 \mathrm{E}+00$ & $3.48 \mathrm{E}+04$ & 4.21E-92 & $2.32 \mathrm{E}-53$ & $2.19 \mathrm{E}+00$ & $9.51 \mathrm{E}-04$ \\
\hline 18 & 7.54E-01 & $4.88 \mathrm{E}-04$ & $0.00 \mathrm{E}+00$ & $0.00 \mathrm{E}+00$ & $3.48 \mathrm{E}+04$ & 4.21E-92 & $2.32 \mathrm{E}-53$ & $2.19 \mathrm{E}+00$ & $9.52 \mathrm{E}-04$ \\
\hline 19 & 7.54E-01 & $4.89 \mathrm{E}-04$ & $0.00 \mathrm{E}+00$ & $0.00 \mathrm{E}+00$ & $3.48 \mathrm{E}+04$ & 4.21E-92 & $2.32 \mathrm{E}-53$ & $2.19 \mathrm{E}+00$ & $9.52 \mathrm{E}-04$ \\
\hline
\end{tabular}

\begin{tabular}{|c|c|c|c|c|c|c|c|c|c|}
\hline \multirow[b]{2}{*}{ Iteration } & \multicolumn{9}{|c|}{ C14 Grout } \\
\hline & Heat (W/yr) & Gamma (W/yr) & Neutron (W/yr) & Neutron (\#/yr) & $\begin{array}{l}\text { Radiotoxicity } \\
\text { (Sv/yr) at } t=0\end{array}$ & $\begin{array}{l}\text { Radiotoxicity } \\
\text { (Sv/yr) at } \\
\mathrm{t}=10,000 \mathrm{yr}\end{array}$ & $\begin{array}{l}\text { 10CFR61 Class C } \\
\text { sum }\end{array}$ & $\begin{array}{l}\text { Waste Mass } \\
(\mathrm{kg} / \mathrm{yr})\end{array}$ & $\begin{array}{l}\text { Volume } \\
\text { (m3/yr) }\end{array}$ \\
\hline 1 & $9.32 \mathrm{E}-07$ & $8.81 \mathrm{E}-09$ & $0.00 E+00$ & $0.00 E+00$ & $6.82 \mathrm{E}-02$ & 2.03E-02 & $5.29 \mathrm{E}-06$ & 5.94E-06 & 2.97E-09 \\
\hline 2 & $9.32 \mathrm{E}-07$ & $8.81 \mathrm{E}-09$ & $0.00 \mathrm{E}+00$ & $0.00 \mathrm{E}+00$ & $6.82 \mathrm{E}-02$ & 2.03E-02 & $5.29 \mathrm{E}-06$ & 5.94E-06 & 2.97E-09 \\
\hline 3 & 9.32E-07 & $8.81 \mathrm{E}-09$ & $0.00 \mathrm{E}+00$ & $0.00 \mathrm{E}+00$ & $6.82 \mathrm{E}-02$ & 2.03E-02 & 5.29E-06 & $5.94 \mathrm{E}-06$ & 2.97E-09 \\
\hline 4 & $9.32 \mathrm{E}-07$ & $8.81 \mathrm{E}-09$ & $0.00 E+00$ & $0.00 E+00$ & $6.82 \mathrm{E}-02$ & 2.03E-02 & $5.29 \mathrm{E}-06$ & 5.94E-06 & 2.97E-09 \\
\hline 5 & $9.32 \mathrm{E}-07$ & $8.81 \mathrm{E}-09$ & $0.00 \mathrm{E}+00$ & $0.00 E+00$ & $6.82 \mathrm{E}-02$ & 2.03E-02 & $5.29 \mathrm{E}-06$ & $5.94 \mathrm{E}-06$ & 2.97E-09 \\
\hline 6 & $9.32 \mathrm{E}-07$ & $8.81 \mathrm{E}-09$ & $0.00 \mathrm{E}+00$ & $0.00 E+00$ & $6.82 \mathrm{E}-02$ & 2.03E-02 & $5.29 \mathrm{E}-06$ & 5.94E-06 & 2.97E-09 \\
\hline 7 & $9.32 \mathrm{E}-07$ & $8.81 \mathrm{E}-09$ & $0.00 \mathrm{E}+00$ & $0.00 E+00$ & $6.82 \mathrm{E}-02$ & 2.03E-02 & $5.29 \mathrm{E}-06$ & $5.94 \mathrm{E}-06$ & 2.97E-09 \\
\hline 8 & $9.32 \mathrm{E}-07$ & $8.81 \mathrm{E}-09$ & $0.00 \mathrm{E}+00$ & $0.00 E+00$ & $6.82 \mathrm{E}-02$ & 2.03E-02 & $5.29 \mathrm{E}-06$ & 5.94E-06 & 2.97E-09 \\
\hline 9 & $9.32 \mathrm{E}-07$ & $8.81 \mathrm{E}-09$ & $0.00 \mathrm{E}+00$ & $0.00 E+00$ & $6.82 \mathrm{E}-02$ & 2.03E-02 & 5.29E-06 & 5.94E-06 & 2.97E-09 \\
\hline 10 & $9.32 \mathrm{E}-07$ & $8.81 \mathrm{E}-09$ & $0.00 \mathrm{E}+00$ & $0.00 E+00$ & $6.82 \mathrm{E}-02$ & $2.03 \mathrm{E}-02$ & 5.29E-06 & $5.94 \mathrm{E}-06$ & 2.97E-09 \\
\hline 11 & $9.32 \mathrm{E}-07$ & $8.81 \mathrm{E}-09$ & $0.00 E+00$ & $0.00 E+00$ & $6.82 \mathrm{E}-02$ & 2.03E-02 & $5.29 \mathrm{E}-06$ & 5.94E-06 & 2.97E-09 \\
\hline 12 & $9.32 \mathrm{E}-07$ & $8.81 \mathrm{E}-09$ & $0.00 \mathrm{E}+00$ & $0.00 E+00$ & $6.82 \mathrm{E}-02$ & 2.03E-02 & 5.29E-06 & 5.94E-06 & 2.97E-09 \\
\hline 13 & 9.32E-07 & $8.81 \mathrm{E}-09$ & $0.00 E+00$ & $0.00 E+00$ & $6.82 \mathrm{E}-02$ & 2.03E-02 & $5.29 \mathrm{E}-06$ & 5.94E-06 & 2.97E-09 \\
\hline 14 & $9.32 \mathrm{E}-07$ & 8.81E-09 & $0.00 E+00$ & $0.00 E+00$ & $6.82 \mathrm{E}-02$ & 2.03E-02 & $5.29 \mathrm{E}-06$ & $5.94 \mathrm{E}-06$ & 2.97E-09 \\
\hline 15 & $9.32 \mathrm{E}-07$ & $8.81 \mathrm{E}-09$ & $0.00 E+00$ & $0.00 E+00$ & $6.82 \mathrm{E}-02$ & 2.03E-02 & 5.29E-06 & 5.94E-06 & 2.97E-09 \\
\hline 16 & $9.32 \mathrm{E}-07$ & $8.81 \mathrm{E}-09$ & $0.00 \mathrm{E}+00$ & $0.00 E+00$ & $6.82 \mathrm{E}-02$ & 2.03E-02 & $5.29 \mathrm{E}-06$ & 5.94E-06 & 2.97E-09 \\
\hline 17 & $9.32 \mathrm{E}-07$ & $8.81 \mathrm{E}-09$ & $0.00 \mathrm{E}+00$ & $0.00 E+00$ & $6.82 \mathrm{E}-02$ & 2.03E-02 & $5.29 \mathrm{E}-06$ & 5.94E-06 & 2.97E-09 \\
\hline 18 & $9.32 \mathrm{E}-07$ & $8.81 \mathrm{E}-09$ & $0.00 \mathrm{E}+00$ & $0.00 E+00$ & $6.82 \mathrm{E}-02$ & 2.03E-02 & 5.29E-06 & 5.94E-06 & 2.97E-09 \\
\hline 19 & $9.32 \mathrm{E}-07$ & $8.81 \mathrm{E}-09$ & $0.00 E+00$ & $0.00 E+00$ & $6.82 \mathrm{E}-02$ & 2.03E-02 & 5.29E-06 & 5.94E-06 & 2.97E-09 \\
\hline
\end{tabular}

Figure C3. Waste stream output information (continued). 


\begin{tabular}{|c|c|c|c|c|c|c|c|c|c|}
\hline \multirow[b]{2}{*}{ Iteration } & \multicolumn{9}{|c|}{ LLW Mineralized Monolith } \\
\hline & Heat (W/yr) & $\begin{array}{l}\text { Gamma } \\
\text { (W/yr) }\end{array}$ & $\begin{array}{l}\text { Neutron } \\
(\mathrm{W} / \mathrm{yr})\end{array}$ & $\begin{array}{l}\text { Neutron } \\
\text { (\#/yr) }\end{array}$ & $\begin{array}{l}\text { Radiotoxicity } \\
\text { (Sv/yr) at t=0 }\end{array}$ & $\begin{array}{l}\text { Radiotoxicity } \\
\text { (Sv/yr) at } \\
\mathrm{t}=10,000 \mathrm{yr}\end{array}$ & $\begin{array}{l}\text { 10CFR61 Class } \\
\text { C sum }\end{array}$ & $\begin{array}{l}\text { Waste Mass } \\
(\mathrm{kg} / \mathrm{yr})\end{array}$ & $\begin{array}{l}\text { Volume } \\
\text { (m3/yr) }\end{array}$ \\
\hline 1 & $0.00 \mathrm{E}+00$ & $0.00 \mathrm{E}+00$ & $0.00 \mathrm{E}+00$ & $0.00 \mathrm{E}+00$ & $0.00 \mathrm{E}+00$ & $0.00 \mathrm{E}+00$ & $0.00 \mathrm{E}+00$ & $5.10 \mathrm{E}+03$ & $4.87 \mathrm{E}+00$ \\
\hline 2 & $0.00 E+00$ & $0.00 \mathrm{E}+00$ & $0.00 \mathrm{E}+00$ & $0.00 \mathrm{E}+00$ & $0.00 \mathrm{E}+00$ & $0.00 \mathrm{E}+00$ & $0.00 \mathrm{E}+00$ & $5.10 \mathrm{E}+03$ & $4.87 \mathrm{E}+00$ \\
\hline 3 & $0.00 E+00$ & $0.00 E+00$ & $0.00 E+00$ & $0.00 \mathrm{E}+00$ & $0.00 \mathrm{E}+00$ & $0.00 \mathrm{E}+00$ & $0.00 \mathrm{E}+00$ & $5.10 \mathrm{E}+03$ & 4.87E+00 \\
\hline 4 & $0.00 E+00$ & $0.00 \mathrm{E}+00$ & $0.00 E+00$ & $0.00 \mathrm{E}+00$ & $0.00 \mathrm{E}+00$ & $0.00 \mathrm{E}+00$ & $0.00 E+00$ & $5.10 \mathrm{E}+03$ & $4.87 E+00$ \\
\hline 5 & $0.00 E+00$ & $0.00 E+00$ & $0.00 \mathrm{E}+00$ & $0.00 \mathrm{E}+00$ & $0.00 \mathrm{E}+00$ & $0.00 \mathrm{E}+00$ & $0.00 \mathrm{E}+00$ & $5.10 \mathrm{E}+03$ & $4.87 \mathrm{E}+00$ \\
\hline 6 & $0.00 E+00$ & $0.00 E+00$ & $0.00 \mathrm{E}+00$ & $0.00 \mathrm{E}+00$ & $0.00 \mathrm{E}+00$ & $0.00 \mathrm{E}+00$ & $0.00 \mathrm{E}+00$ & $5.10 E+03$ & $4.87 \mathrm{E}+00$ \\
\hline 7 & $0.00 E+00$ & $0.00 \mathrm{E}+00$ & $0.00 \mathrm{E}+00$ & $0.00 \mathrm{E}+00$ & $0.00 \mathrm{E}+00$ & $0.00 E+00$ & $0.00 \mathrm{E}+00$ & $5.10 \mathrm{E}+03$ & $4.87 \mathrm{E}+00$ \\
\hline 8 & $0.00 E+00$ & $0.00 E+00$ & $0.00 \mathrm{E}+00$ & $0.00 \mathrm{E}+00$ & $0.00 \mathrm{E}+00$ & $0.00 E+00$ & $0.00 \mathrm{E}+00$ & $5.10 \mathrm{E}+03$ & $4.87 E+00$ \\
\hline 9 & $0.00 E+00$ & $0.00 \mathrm{E}+00$ & $0.00 E+00$ & $0.00 \mathrm{E}+00$ & $0.00 E+00$ & $0.00 \mathrm{E}+00$ & $0.00 E+00$ & $5.10 \mathrm{E}+03$ & $4.87 E+00$ \\
\hline 10 & $0.00 E+00$ & $0.00 \mathrm{E}+00$ & $0.00 \mathrm{E}+00$ & $0.00 \mathrm{E}+00$ & $0.00 \mathrm{E}+00$ & $0.00 \mathrm{E}+00$ & $0.00 \mathrm{E}+00$ & $5.10 \mathrm{E}+03$ & $4.87 \mathrm{E}+00$ \\
\hline 11 & $0.00 E+00$ & $0.00 \mathrm{E}+00$ & $0.00 \mathrm{E}+00$ & $0.00 \mathrm{E}+00$ & $0.00 \mathrm{E}+00$ & $0.00 \mathrm{E}+00$ & $0.00 \mathrm{E}+00$ & $5.10 \mathrm{E}+03$ & $4.87 E+00$ \\
\hline 12 & $0.00 E+00$ & $0.00 \mathrm{E}+00$ & $0.00 \mathrm{E}+00$ & $0.00 \mathrm{E}+00$ & $0.00 \mathrm{E}+00$ & $0.00 \mathrm{E}+00$ & $0.00 \mathrm{E}+00$ & $5.10 \mathrm{E}+03$ & $4.87 \mathrm{E}+00$ \\
\hline 13 & $0.00 E+00$ & $0.00 \mathrm{E}+00$ & $0.00 \mathrm{E}+00$ & $0.00 \mathrm{E}+00$ & $0.00 \mathrm{E}+00$ & $0.00 \mathrm{E}+00$ & $0.00 E+00$ & $5.10 \mathrm{E}+03$ & $4.87 E+00$ \\
\hline 14 & $0.00 E+00$ & $0.00 \mathrm{E}+00$ & $0.00 \mathrm{E}+00$ & $0.00 \mathrm{E}+00$ & $0.00 \mathrm{E}+00$ & $0.00 \mathrm{E}+00$ & $0.00 E+00$ & $5.10 \mathrm{E}+03$ & $4.87 E+00$ \\
\hline 15 & $0.00 E+00$ & $0.00 \mathrm{E}+00$ & $0.00 E+00$ & $0.00 \mathrm{E}+00$ & $0.00 \mathrm{E}+00$ & $0.00 \mathrm{E}+00$ & $0.00 E+00$ & $5.10 \mathrm{E}+03$ & $4.87 E+00$ \\
\hline 16 & $0.00 E+00$ & $0.00 \mathrm{E}+00$ & $0.00 E+00$ & $0.00 \mathrm{E}+00$ & $0.00 E+00$ & $0.00 \mathrm{E}+00$ & $0.00 E+00$ & $5.10 \mathrm{E}+03$ & $4.87 E+00$ \\
\hline 17 & $0.00 E+00$ & $0.00 \mathrm{E}+00$ & $0.00 \mathrm{E}+00$ & $0.00 \mathrm{E}+00$ & $0.00 \mathrm{E}+00$ & $0.00 \mathrm{E}+00$ & $0.00 \mathrm{E}+00$ & $5.10 \mathrm{E}+03$ & $4.87 \mathrm{E}+00$ \\
\hline 18 & $0.00 E+00$ & $0.00 \mathrm{E}+00$ & $0.00 \mathrm{E}+00$ & $0.00 \mathrm{E}+00$ & $0.00 \mathrm{E}+00$ & $0.00 E+00$ & $0.00 E+00$ & $5.10 E+03$ & $4.87 E+00$ \\
\hline 19 & $0.00 E+00$ & $0.00 E+00$ & $0.00 E+00$ & $0.00 E+00$ & $0.00 E+00$ & $0.00 E+00$ & $0.00 E+00$ & $5.10 E+03$ & $4.87 \mathrm{E}+00$ \\
\hline
\end{tabular}

\begin{tabular}{|c|c|c|c|c|c|c|c|c|c|}
\hline \multirow[b]{2}{*}{ Iteration } & \multicolumn{9}{|c|}{ TRU Mineralized Monolith } \\
\hline & Heat (W/yr) & $\begin{array}{l}\text { Gamma } \\
\text { (W/yr) }\end{array}$ & $\begin{array}{l}\text { Neutron } \\
\text { (W/yr) }\end{array}$ & Neutron (\#/yr) & $\begin{array}{l}\text { Radiotoxicity } \\
\text { (Sv/yr) at } t=0\end{array}$ & $\begin{array}{l}\text { Radiotoxicity } \\
\text { (Sv/yr) at } \\
\mathrm{t}=10,000 \mathrm{yr}\end{array}$ & $\begin{array}{l}\text { 10CFR61 Class } \\
\text { C sum }\end{array}$ & $\begin{array}{l}\text { Waste Mass } \\
(\mathrm{kg} / \mathrm{yr})\end{array}$ & $\begin{array}{l}\text { Volume } \\
\text { (m3/yr) }\end{array}$ \\
\hline 1 & $0.00 \mathrm{E}+00$ & $0.00 \mathrm{E}+00$ & $0.00 \mathrm{E}+00$ & $0.00 \mathrm{E}+00$ & $0.00 \mathrm{E}+00$ & $0.00 \mathrm{E}+00$ & $0.00 \mathrm{E}+00$ & $4.52 E+00$ & $5.75 \mathrm{E}-03$ \\
\hline 2 & $0.00 E+00$ & $0.00 \mathrm{E}+00$ & $0.00 E+00$ & $0.00 E+00$ & $0.00 \mathrm{E}+00$ & $0.00 E+00$ & $0.00 E+00$ & $4.52 E+00$ & $5.75 \mathrm{E}-03$ \\
\hline 3 & $0.00 \mathrm{E}+00$ & $0.00 \mathrm{E}+00$ & $0.00 \mathrm{E}+00$ & $0.00 \mathrm{E}+00$ & $0.00 \mathrm{E}+00$ & $0.00 \mathrm{E}+00$ & $0.00 \mathrm{E}+00$ & $4.52 E+00$ & $5.75 \mathrm{E}-03$ \\
\hline 4 & $0.00 \mathrm{E}+00$ & $0.00 \mathrm{E}+00$ & $0.00 \mathrm{E}+00$ & $0.00 \mathrm{E}+00$ & $0.00 \mathrm{E}+00$ & $0.00 \mathrm{E}+00$ & $0.00 \mathrm{E}+00$ & $4.52 E+00$ & $5.75 \mathrm{E}-03$ \\
\hline 5 & $0.00 \mathrm{E}+00$ & $0.00 \mathrm{E}+00$ & $0.00 \mathrm{E}+00$ & $0.00 E+00$ & $0.00 \mathrm{E}+00$ & $0.00 \mathrm{E}+00$ & $0.00 E+00$ & $4.52 E+00$ & $5.75 \mathrm{E}-03$ \\
\hline 6 & $0.00 E+00$ & $0.00 E+00$ & $0.00 \mathrm{E}+00$ & $0.00 \mathrm{E}+00$ & $0.00 \mathrm{E}+00$ & $0.00 \mathrm{E}+00$ & $0.00 \mathrm{E}+00$ & $4.52 E+00$ & $5.75 \mathrm{E}-03$ \\
\hline 7 & $0.00 \mathrm{E}+00$ & $0.00 \mathrm{E}+00$ & $0.00 \mathrm{E}+00$ & $0.00 \mathrm{E}+00$ & $0.00 \mathrm{E}+00$ & $0.00 \mathrm{E}+00$ & $0.00 \mathrm{E}+00$ & $4.52 E+00$ & $5.75 \mathrm{E}-03$ \\
\hline 8 & $0.00 \mathrm{E}+00$ & $0.00 \mathrm{E}+00$ & $0.00 \mathrm{E}+00$ & $0.00 \mathrm{E}+00$ & $0.00 \mathrm{E}+00$ & $0.00 \mathrm{E}+00$ & $0.00 E+00$ & $4.52 E+00$ & $5.75 \mathrm{E}-03$ \\
\hline 9 & $0.00 E+00$ & $0.00 E+00$ & $0.00 \mathrm{E}+00$ & $0.00 \mathrm{E}+00$ & $0.00 \mathrm{E}+00$ & $0.00 \mathrm{E}+00$ & $0.00 E+00$ & $4.52 E+00$ & $5.75 \mathrm{E}-03$ \\
\hline 10 & $0.00 \mathrm{E}+00$ & $0.00 \mathrm{E}+00$ & $0.00 \mathrm{E}+00$ & $0.00 \mathrm{E}+00$ & $0.00 \mathrm{E}+00$ & $0.00 \mathrm{E}+00$ & $0.00 E+00$ & $4.52 E+00$ & $5.75 \mathrm{E}-03$ \\
\hline 11 & $0.00 E+00$ & $0.00 E+00$ & $0.00 \mathrm{E}+00$ & $0.00 E+00$ & $0.00 \mathrm{E}+00$ & $0.00 E+00$ & $0.00 E+00$ & $4.52 E+00$ & $5.75 \mathrm{E}-03$ \\
\hline 12 & $0.00 \mathrm{E}+00$ & $0.00 E+00$ & $0.00 \mathrm{E}+00$ & $0.00 E+00$ & $0.00 E+00$ & $0.00 E+00$ & $0.00 E+00$ & $4.52 E+00$ & $5.75 \mathrm{E}-03$ \\
\hline 13 & $0.00 \mathrm{E}+00$ & $0.00 \mathrm{E}+00$ & $0.00 \mathrm{E}+00$ & $0.00 \mathrm{E}+00$ & $0.00 \mathrm{E}+00$ & $0.00 \mathrm{E}+00$ & $0.00 E+00$ & $4.52 E+00$ & $5.75 \mathrm{E}-03$ \\
\hline 14 & $0.00 \mathrm{E}+00$ & $0.00 \mathrm{E}+00$ & $0.00 \mathrm{E}+00$ & $0.00 E+00$ & $0.00 \mathrm{E}+00$ & $0.00 \mathrm{E}+00$ & $0.00 E+00$ & $4.52 E+00$ & $5.75 \mathrm{E}-03$ \\
\hline 15 & $0.00 \mathrm{E}+00$ & $0.00 \mathrm{E}+00$ & $0.00 \mathrm{E}+00$ & $0.00 \mathrm{E}+00$ & $0.00 \mathrm{E}+00$ & $0.00 E+00$ & $0.00 E+00$ & $4.52 E+00$ & $5.75 \mathrm{E}-03$ \\
\hline 16 & $0.00 E+00$ & $0.00 \mathrm{E}+00$ & $0.00 \mathrm{E}+00$ & $0.00 E+00$ & $0.00 \mathrm{E}+00$ & $0.00 E+00$ & $0.00 E+00$ & $4.52 E+00$ & $5.75 \mathrm{E}-03$ \\
\hline 17 & $0.00 \mathrm{E}+00$ & $0.00 \mathrm{E}+00$ & $0.00 \mathrm{E}+00$ & $0.00 \mathrm{E}+00$ & $0.00 \mathrm{E}+00$ & $0.00 \mathrm{E}+00$ & $0.00 E+00$ & $4.52 E+00$ & $5.75 \mathrm{E}-03$ \\
\hline 18 & $0.00 \mathrm{E}+00$ & $0.00 \mathrm{E}+00$ & $0.00 \mathrm{E}+00$ & $0.00 E+00$ & $0.00 \mathrm{E}+00$ & $0.00 \mathrm{E}+00$ & $0.00 E+00$ & $4.52 E+00$ & $5.75 \mathrm{E}-03$ \\
\hline 19 & $0.00 \mathrm{E}+00$ & $0.00 \mathrm{E}+00$ & $0.00 \mathrm{E}+00$ & $0.00 \mathrm{E}+00$ & $0.00 \mathrm{E}+00$ & $0.00 \mathrm{E}+00$ & $0.00 \mathrm{E}+00$ & $4.52 E+00$ & $5.75 \mathrm{E}-03$ \\
\hline
\end{tabular}

Figure C3. Waste stream output information (continued). 
The FIT 2 Model

May 13, 2011

\begin{tabular}{|c|c|c|c|c|c|c|c|c|c|}
\hline \multirow[b]{2}{*}{ Iteration } & \multicolumn{9}{|c|}{ Glass } \\
\hline & Heat (W/yr) & $\begin{array}{l}\text { Gamma } \\
\text { (W/yr) }\end{array}$ & $\begin{array}{l}\text { Neutron } \\
\text { (W/yr) }\end{array}$ & Neutron (\#/yr) & $\begin{array}{l}\text { Radiotoxicity } \\
\text { (Sv/yr) at t }=0\end{array}$ & $\begin{array}{l}\text { Radiotoxıcity } \\
\text { (Sv/yr) at } \\
\mathrm{t}=10,000 \mathrm{yr}\end{array}$ & $\begin{array}{l}\text { 10CFR61 Class } \\
\text { C sum }\end{array}$ & $\begin{array}{l}\text { Waste Mass } \\
(\mathrm{kg} / \mathrm{yr})\end{array}$ & $\begin{array}{l}\text { Volume } \\
\text { (m3/yr) }\end{array}$ \\
\hline 1 & $9.91 \mathrm{E}+05$ & $6.22 \mathrm{E}+02$ & $\begin{array}{l}3.44 \mathrm{E}-07 \\
\end{array}$ & $2.15 E+06$ & $4.75 \mathrm{E}+08$ & $1.62 \mathrm{E}+04$ & $3.68 \mathrm{E}+02$ & $3.71 \mathrm{E}+02$ & $1.40 \mathrm{E}-01$ \\
\hline 2 & $1.36 \mathrm{E}+06$ & $8.61 E+02$ & $6.08 \mathrm{E}-07$ & $3.79 E+06$ & $6.64 \mathrm{E}+08$ & $2.10 E+04$ & $4.27 E+02$ & $4.02 E+02$ & $1.52 \mathrm{E}-01$ \\
\hline 3 & $1.66 \mathrm{E}+06$ & $1.08 \mathrm{E}+03$ & 8.65E-07 & $5.40 \mathrm{E}+06$ & $8.01 E+08$ & $2.47 E+04$ & $4.76 \mathrm{E}+02$ & $4.24 E+02$ & 1.60E-01 \\
\hline 4 & $1.90 E+06$ & $1.24 \mathrm{E}+03$ & 1.10E-06 & $6.89 \mathrm{E}+06$ & $9.04 \mathrm{E}+08$ & $2.76 \mathrm{E}+04$ & $5.14 \mathrm{E}+02$ & 4.40E+02 & $1.67 \mathrm{E}-01$ \\
\hline 5 & $2.09 E+06$ & $1.36 \mathrm{E}+03$ & 1.33E-06 & $8.28 \mathrm{E}+06$ & $9.81 E+08$ & $2.98 \mathrm{E}+04$ & $5.43 E+02$ & $4.52 E+02$ & $1.71 \mathrm{E}-01$ \\
\hline 6 & $2.23 \mathrm{E}+06$ & $1.44 \mathrm{E}+03$ & 1.53E-06 & $9.56 \mathrm{E}+06$ & $1.04 \mathrm{E}+09$ & $3.15 E+04$ & $5.65 \mathrm{E}+02$ & $4.61 E+02$ & 1.75E-01 \\
\hline 7 & $2.35 \mathrm{E}+06$ & $1.51 E+03$ & $1.73 \mathrm{E}-06$ & $1.08 \mathrm{E}+07$ & $1.08 \mathrm{E}+09$ & $3.28 \mathrm{E}+04$ & $5.82 E+02$ & $4.68 \mathrm{E}+02$ & $1.77 \mathrm{E}-01$ \\
\hline 8 & $2.43 E+06$ & $1.56 \mathrm{E}+03$ & $1.91 \mathrm{E}-06$ & $1.19 \mathrm{E}+07$ & $1.12 E+09$ & $3.38 \mathrm{E}+04$ & $5.95 \mathrm{E}+02$ & $4.73 E+02$ & 1.79E-01 \\
\hline 9 & $2.50 E+06$ & $1.59 E+03$ & 2.09E-06 & $1.31 E+07$ & $1.14 \mathrm{E}+09$ & $3.45 \mathrm{E}+04$ & $6.04 E+02$ & $4.75 \mathrm{E}+02$ & 1.80E-01 \\
\hline 10 & $2.55 E+06$ & $1.62 \mathrm{E}+03$ & $2.26 \mathrm{E}-06$ & $1.41 \mathrm{E}+07$ & $1.16 \mathrm{E}+09$ & $3.51 E+04$ & $6.11 E+02$ & $4.78 \mathrm{E}+02$ & $1.81 \mathrm{E}-01$ \\
\hline 11 & $2.59 \mathrm{E}+06$ & $1.64 \mathrm{E}+03$ & $2.43 \mathrm{E}-06$ & $1.52 \mathrm{E}+07$ & $1.18 \mathrm{E}+09$ & $3.55 E+04$ & $6.17 \mathrm{E}+02$ & $4.80 E+02$ & $1.82 \mathrm{E}-01$ \\
\hline 12 & $2.62 E+06$ & $1.66 \mathrm{E}+03$ & 2.59E-06 & $1.62 \mathrm{E}+07$ & $1.19 \mathrm{E}+09$ & $3.58 \mathrm{E}+04$ & $6.21 E+02$ & $4.82 E+02$ & $1.83 \mathrm{E}-01$ \\
\hline 13 & $2.64 \mathrm{E}+06$ & $1.67 E+03$ & 2.74E-06 & $1.71 \mathrm{E}+07$ & $1.20 \mathrm{E}+09$ & $3.61 E+04$ & $6.24 E+02$ & $4.83 E+02$ & $1.83 \mathrm{E}-01$ \\
\hline 14 & $2.66 \mathrm{E}+06$ & $1.68 \mathrm{E}+03$ & $2.88 \mathrm{E}-06$ & $1.80 \mathrm{E}+07$ & $1.20 \mathrm{E}+09$ & $3.63 E+04$ & $6.27 E+02$ & $4.84 E+02$ & $1.83 \mathrm{E}-01$ \\
\hline 15 & $2.67 E+06$ & $1.68 \mathrm{E}+03$ & $3.02 \mathrm{E}-06$ & $1.88 \mathrm{E}+07$ & $1.21 \mathrm{E}+09$ & $3.65 E+04$ & $6.29 E+02$ & $4.85 \mathrm{E}+02$ & $1.84 \mathrm{E}-01$ \\
\hline 16 & $2.68 \mathrm{E}+06$ & $1.69 \mathrm{E}+03$ & 3.14E-06 & $1.96 \mathrm{E}+07$ & $1.21 \mathrm{E}+09$ & $3.66 \mathrm{E}+04$ & $6.30 E+02$ & $4.86 \mathrm{E}+02$ & $1.84 \mathrm{E}-01$ \\
\hline 17 & $2.69 E+06$ & $1.69 \mathrm{E}+03$ & 3.26E-06 & $2.03 E+07$ & $1.21 \mathrm{E}+09$ & $3.67 E+04$ & $6.31 E+02$ & $4.86 E+02$ & $1.84 \mathrm{E}-01$ \\
\hline 18 & $2.69 \mathrm{E}+06$ & $1.70 E+03$ & 3.36E-06 & $2.10 \mathrm{E}+07$ & $1.22 \mathrm{E}+09$ & $3.67 E+04$ & $6.32 E+02$ & $4.86 \mathrm{E}+02$ & $1.84 \mathrm{E}-01$ \\
\hline 19 & $2.70 E+06$ & $1.70 \mathrm{E}+03$ & $3.45 E-06$ & $2.16 \mathrm{E}+07$ & $1.22 \mathrm{E}+09$ & $3.68 \mathrm{E}+04$ & $6.33 E+02$ & $4.87 \mathrm{E}+02$ & $1.84 \mathrm{E}-01$ \\
\hline
\end{tabular}

\begin{tabular}{|c|c|c|c|c|c|c|c|c|c|}
\hline \multirow[b]{2}{*}{ Iteration } & \multicolumn{9}{|c|}{ Fuel Fab Waste } \\
\hline & Heat (W/yr) & $\begin{array}{l}\text { Gamma } \\
\text { (W/yr) }\end{array}$ & $\begin{array}{l}\text { Neutron } \\
\text { (W/yr) }\end{array}$ & Neutron (\#/yr) & $\begin{array}{l}\text { Radiotoxicity } \\
(\text { Sv/yr) at t }=0\end{array}$ & $\begin{array}{l}\text { Radiotoxicity } \\
\text { (Sv/yr) at } \\
\mathrm{t}=10,000 \mathrm{yr}\end{array}$ & $\begin{array}{l}\text { 10CFR61 Class } \\
\text { C sum }\end{array}$ & $\begin{array}{l}\text { Waste Mass } \\
(\mathrm{kg} / \mathrm{yr})\end{array}$ & $\begin{array}{l}\text { Volume } \\
\text { (m3/yr) }\end{array}$ \\
\hline 1 & $1.56 \mathrm{E}+08$ & 3 3.39E-01 & 3.54E-05 & $2.21 \mathrm{E}+08$ & $3.25 \mathrm{E}+07$ & $1.40 \mathrm{E}+06$ & $3.52 \mathrm{E}+01$ & $2.33 \mathrm{E}+01$ & $1.30 \mathrm{E}-02$ \\
\hline 2 & $2.74 \mathrm{E}+08$ & $1.31 E+00$ & $1.12 \mathrm{E}-04$ & $6.97 \mathrm{E}+08$ & $7.40 \mathrm{E}+07$ & $2.50 E+06$ & $5.54 \mathrm{E}+01$ & $3.78 \mathrm{E}+01$ & $2.10 \mathrm{E}-02$ \\
\hline 3 & $3.74 \mathrm{E}+08$ & $1.64 \mathrm{E}+00$ & 1.97E-04 & $1.23 \mathrm{E}+09$ & $1.11 \mathrm{E}+08$ & $3.38 \mathrm{E}+06$ & $7.06 \mathrm{E}+01$ & $4.80 E+01$ & $2.66 \mathrm{E}-02$ \\
\hline 4 & $4.55 \mathrm{E}+08$ & $1.91 \mathrm{E}+00$ & $2.80 \mathrm{E}-04$ & $1.75 E+09$ & $1.42 \mathrm{E}+08$ & $4.06 \mathrm{E}+06$ & $8.29 E+01$ & $5.54 \mathrm{E}+01$ & $3.08 \mathrm{E}-02$ \\
\hline 5 & $5.21 E+08$ & $2.12 \mathrm{E}+00$ & $3.58 \mathrm{E}-04$ & $2.24 \mathrm{E}+09$ & $1.67 \mathrm{E}+08$ & $4.59 \mathrm{E}+06$ & $9.29 E+01$ & $6.08 \mathrm{E}+01$ & $3.38 \mathrm{E}-02$ \\
\hline 6 & $5.73 E+08$ & $2.28 \mathrm{E}+00$ & 4.30E-04 & $2.69 \mathrm{E}+09$ & $1.87 \mathrm{E}+08$ & $5.00 E+06$ & $1.01 \mathrm{E}+02$ & $6.48 \mathrm{E}+01$ & 3.60E-02 \\
\hline 7 & $6.13 E+08$ & $2.40 E+00$ & 4.97E-04 & $3.10 E+09$ & $2.03 E+08$ & $5.32 \mathrm{E}+06$ & $1.07 E+02$ & $6.78 \mathrm{E}+01$ & 3.77E-02 \\
\hline 8 & $6.44 \mathrm{E}+08$ & $2.50 \mathrm{E}+00$ & 5.60E-04 & $3.49 E+09$ & $2.16 \mathrm{E}+08$ & $5.56 \mathrm{E}+06$ & $1.13 \mathrm{E}+02$ & $7.01 \mathrm{E}+01$ & $3.89 \mathrm{E}-02$ \\
\hline 9 & $6.67 E+08$ & $2.57 \mathrm{E}+00$ & 6.19E-04 & $3.86 \mathrm{E}+09$ & $2.27 \mathrm{E}+08$ & $5.75 E+06$ & $1.17 \mathrm{E}+02$ & $7.18 \mathrm{E}+01$ & $3.99 \mathrm{E}-02$ \\
\hline 10 & $6.86 \mathrm{E}+08$ & $2.63 \mathrm{E}+00$ & $6.75 \mathrm{E}-04$ & $4.22 \mathrm{E}+09$ & $2.35 \mathrm{E}+08$ & $5.90 E+06$ & $1.20 E+02$ & $7.30 E+01$ & 4.06E-02 \\
\hline 11 & $6.99 \mathrm{E}+08$ & $2.67 E+00$ & $7.29 \mathrm{E}-04$ & $4.55 E+09$ & $2.42 \mathrm{E}+08$ & $6.01 E+06$ & $1.23 \mathrm{E}+02$ & $7.40 \mathrm{E}+01$ & 4.11E-02 \\
\hline 12 & $7.10 E+08$ & $2.71 E+00$ & $7.81 \mathrm{E}-04$ & $4.87 E+09$ & $2.47 E+08$ & $6.10 E+06$ & $1.25 \mathrm{E}+02$ & $7.47 \mathrm{E}+01$ & 4.15E-02 \\
\hline 13 & $7.18 \mathrm{E}+08$ & $2.73 E+00$ & $8.29 \mathrm{E}-04$ & $5.18 \mathrm{E}+09$ & $2.52 E+08$ & $6.16 E+06$ & $1.26 \mathrm{E}+02$ & $7.52 \mathrm{E}+01$ & $4.18 \mathrm{E}-02$ \\
\hline 14 & $7.24 \mathrm{E}+08$ & $2.76 \mathrm{E}+00$ & $8.75 E-04$ & $5.46 \mathrm{E}+09$ & $2.55 \mathrm{E}+08$ & $6.21 \mathrm{E}+06$ & $1.28 \mathrm{E}+02$ & $7.56 \mathrm{E}+01$ & 4.20E-02 \\
\hline 15 & $7.28 \mathrm{E}+08$ & $2.77 \mathrm{E}+00$ & $9.18 \mathrm{E}-04$ & $5.73 E+09$ & $2.58 \mathrm{E}+08$ & $6.25 \mathrm{E}+06$ & $1.29 \mathrm{E}+02$ & $7.60 E+01$ & 4.22E-02 \\
\hline 16 & $7.32 \mathrm{E}+08$ & $2.78 \mathrm{E}+00$ & $9.58 \mathrm{E}-04$ & $5.98 \mathrm{E}+09$ & $2.60 \mathrm{E}+08$ & $6.28 \mathrm{E}+06$ & $1.30 E+02$ & $7.62 E+01$ & 4.23E-02 \\
\hline 17 & $7.34 \mathrm{E}+08$ & $2.79 \mathrm{E}+00$ & $9.95 \mathrm{E}-04$ & $6.21 \mathrm{E}+09$ & $2.62 E+08$ & $6.31 E+06$ & $1.30 \mathrm{E}+02$ & $7.64 \mathrm{E}+01$ & 4.24E- 02 \\
\hline 18 & $7.37 \mathrm{E}+08$ & $2.80 \mathrm{E}+00$ & $1.03 \mathrm{E}-03$ & $6.42 E+09$ & $2.63 \mathrm{E}+08$ & $6.33 E+06$ & $1.31 \mathrm{E}+02$ & $7.66 \mathrm{E}+01$ & 4. $25 \mathrm{E}-02$ \\
\hline 19 & $7.38 \mathrm{E}+08$ & $2.81 E+00$ & $1.06 \mathrm{E}-03$ & $6.61 E+09$ & $2.64 \mathrm{E}+08$ & $6.34 \mathrm{E}+06$ & $1.31 \mathrm{E}+02$ & $7.67 \mathrm{E}+01$ & 4.26E-02 \\
\hline
\end{tabular}

Figure C3. Waste stream output information (continued). 


\begin{tabular}{|c|c|c|c|c|c|c|c|c|c|}
\hline \multirow[b]{2}{*}{ Iteration } & \multicolumn{9}{|c|}{ Lanthinide Glass } \\
\hline & Heat (W/yr) & $\begin{array}{l}\text { Gamma } \\
\text { (W/yr) }\end{array}$ & $\begin{array}{l}\text { Neutron } \\
\text { (W/yr) }\end{array}$ & Neutron (\#/yr) & $\begin{array}{l}\text { Radiotoxicity } \\
\text { (Sv/yr) at t=0 }\end{array}$ & $\begin{array}{l}\text { Radiotoxicity } \\
\text { (Sv/yr) at } \\
\mathrm{t}=10,000 \mathrm{yr}\end{array}$ & $\begin{array}{l}\text { 10CFR61 Class } \\
\text { C sum }\end{array}$ & $\begin{array}{l}\text { Waste Mass } \\
\text { (kg/yr) }\end{array}$ & $\begin{array}{l}\text { Volume } \\
\text { (m3/yr) }\end{array}$ \\
\hline 1 & $4.00 E+05$ & $2.27 \mathrm{E}+03$ & $\begin{array}{l}3.72 \mathrm{E}-07 \\
\end{array}$ & $1.07 \mathrm{E}+06$ & $3.34 \mathrm{E}+08$ & $3.57 \mathrm{E}+03$ & $4.53 E+00$ & $2.82 \mathrm{E}+03$ & $1.13 \mathrm{E}+00$ \\
\hline 2 & $5.47 E+05$ & $2.47 E+03$ & 3.04E-07 & $1.90 E+06$ & $4.51 E+08$ & $4.84 \mathrm{E}+03$ & $7.16 \mathrm{E}+00$ & $2.98 \mathrm{E}+03$ & $1.19 \mathrm{E}+00$ \\
\hline 3 & $6.67 \mathrm{E}+05$ & $2.61 \mathrm{E}+03$ & 4.32E-07 & $2.70 \mathrm{E}+06$ & $5.35 \mathrm{E}+08$ & $5.84 \mathrm{E}+03$ & $9.10 E+00$ & $3.10 E+03$ & $1.24 \mathrm{E}+00$ \\
\hline 4 & $7.63 \mathrm{E}+05$ & $2.71 E+03$ & $5.52 \mathrm{E}-07$ & $3.44 \mathrm{E}+06$ & $5.97 E+08$ & $6.62 E+03$ & $1.06 \mathrm{E}+01$ & $3.19 E+03$ & $1.27 \mathrm{E}+00$ \\
\hline 5 & $8.40 E+05$ & $2.79 \mathrm{E}+03$ & $6.63 \mathrm{E}-07$ & $4.14 \mathrm{E}+06$ & $6.43 E+08$ & $7.22 \mathrm{E}+03$ & 1.17E+01 & $3.25 \mathrm{E}+03$ & $1.30 \mathrm{E}+00$ \\
\hline 6 & $8.98 \mathrm{E}+05$ & $2.85 \mathrm{E}+03$ & 7.65E-07 & $4.78 \mathrm{E}+06$ & $6.77 \mathrm{E}+08$ & $7.68 \mathrm{E}+03$ & $1.26 \mathrm{E}+01$ & $3.30 \mathrm{E}+03$ & $1.32 \mathrm{E}+00$ \\
\hline 7 & $9.44 \mathrm{E}+05$ & $2.90 \mathrm{E}+03$ & 8.63E-07 & $5.39 \mathrm{E}+06$ & $7.03 E+08$ & $8.04 E+03$ & $1.32 \mathrm{E}+01$ & $3.34 \mathrm{E}+03$ & $1.33 \mathrm{E}+00$ \\
\hline 8 & $9.79 \mathrm{E}+05$ & $2.93 \mathrm{E}+03$ & $9.56 \mathrm{E}-07$ & 5.97E+06 & $7.23 \mathrm{E}+08$ & $8.32 \mathrm{E}+03$ & $1.37 \mathrm{E}+01$ & $3.36 \mathrm{E}+03$ & $1.35 \mathrm{E}+00$ \\
\hline 9 & $1.01 \mathrm{E}+06$ & $2.96 \mathrm{E}+03$ & $1.05 \mathrm{E}-06$ & $6.53 \mathrm{E}+06$ & $7.37 \mathrm{E}+08$ & $8.53 E+03$ & $1.42 \mathrm{E}+01$ & $3.39 E+03$ & $1.35 \mathrm{E}+00$ \\
\hline 10 & $1.03 E+06$ & $2.98 \mathrm{E}+03$ & $1.13 \mathrm{E}-06$ & $7.07 E+06$ & $7.49 \mathrm{E}+08$ & $8.69 \mathrm{E}+03$ & $1.45 \mathrm{E}+01$ & $3.40 \mathrm{E}+03$ & $1.36 \mathrm{E}+00$ \\
\hline 11 & $1.04 \mathrm{E}+06$ & $2.99 \mathrm{E}+03$ & $1.22 \mathrm{E}-06$ & $7.58 \mathrm{E}+06$ & $7.57 \mathrm{E}+08$ & $8.82 E+03$ & 1.47E+01 & $3.41 \mathrm{E}+03$ & $1.37 \mathrm{E}+00$ \\
\hline 12 & $1.05 E+06$ & $3.00 \mathrm{E}+03$ & $1.29 \mathrm{E}-06$ & $8.08 \mathrm{E}+06$ & $7.63 E+08$ & $8.92 E+03$ & $1.49 \mathrm{E}+01$ & $3.42 \mathrm{E}+03$ & $1.37 \mathrm{E}+00$ \\
\hline 13 & $1.06 \mathrm{E}+06$ & $3.01 E+03$ & 1.37E-06 & $8.55 E+06$ & $7.68 \mathrm{E}+08$ & $8.99 E+03$ & $1.51 \mathrm{E}+01$ & $3.43 E+03$ & $1.37 \mathrm{E}+00$ \\
\hline 14 & $1.07 \mathrm{E}+06$ & $3.02 E+03$ & $1.44 \mathrm{E}-06$ & $9.00 \mathrm{E}+06$ & $7.72 E+08$ & $9.05 E+03$ & $1.52 \mathrm{E}+01$ & $3.43 E+03$ & $1.37 \mathrm{E}+00$ \\
\hline 15 & $1.07 \mathrm{E}+06$ & $3.02 \mathrm{E}+03$ & $1.51 \mathrm{E}-06$ & $9.42 E+06$ & $7.75 \mathrm{E}+08$ & $9.09 \mathrm{E}+03$ & $1.53 \mathrm{E}+01$ & $3.44 \mathrm{E}+03$ & $1.38 \mathrm{E}+00$ \\
\hline 16 & $1.08 \mathrm{E}+06$ & $3.03 \mathrm{E}+03$ & 1.57E-06 & $9.80 E+06$ & 7.77E+08 & $9.13 \mathrm{E}+03$ & $1.53 \mathrm{E}+01$ & $3.44 \mathrm{E}+03$ & $1.38 \mathrm{E}+00$ \\
\hline 17 & $1.08 \mathrm{E}+06$ & $3.03 E+03$ & $1.63 \mathrm{E}-06$ & $1.02 \mathrm{E}+07$ & $7.79 E+08$ & $9.16 E+03$ & $1.54 \mathrm{E}+01$ & $3.44 \mathrm{E}+03$ & $1.38 \mathrm{E}+00$ \\
\hline 18 & $1.08 \mathrm{E}+06$ & $3.03 E+03$ & $1.68 \mathrm{E}-06$ & $1.05 \mathrm{E}+07$ & $7.81 \mathrm{E}+08$ & $9.18 \mathrm{E}+03$ & $1.54 \mathrm{E}+01$ & $3.45 \mathrm{E}+03$ & $1.38 \mathrm{E}+00$ \\
\hline 19 & $1.09 E+06$ & $3.03 E+03$ & $1.73 E-06$ & $1.08 \mathrm{E}+07$ & $7.82 \mathrm{E}+08$ & $9.20 \mathrm{E}+03$ & $1.55 \mathrm{E}+01$ & $3.45 \mathrm{E}+03$ & $1.38 \mathrm{E}+00$ \\
\hline
\end{tabular}

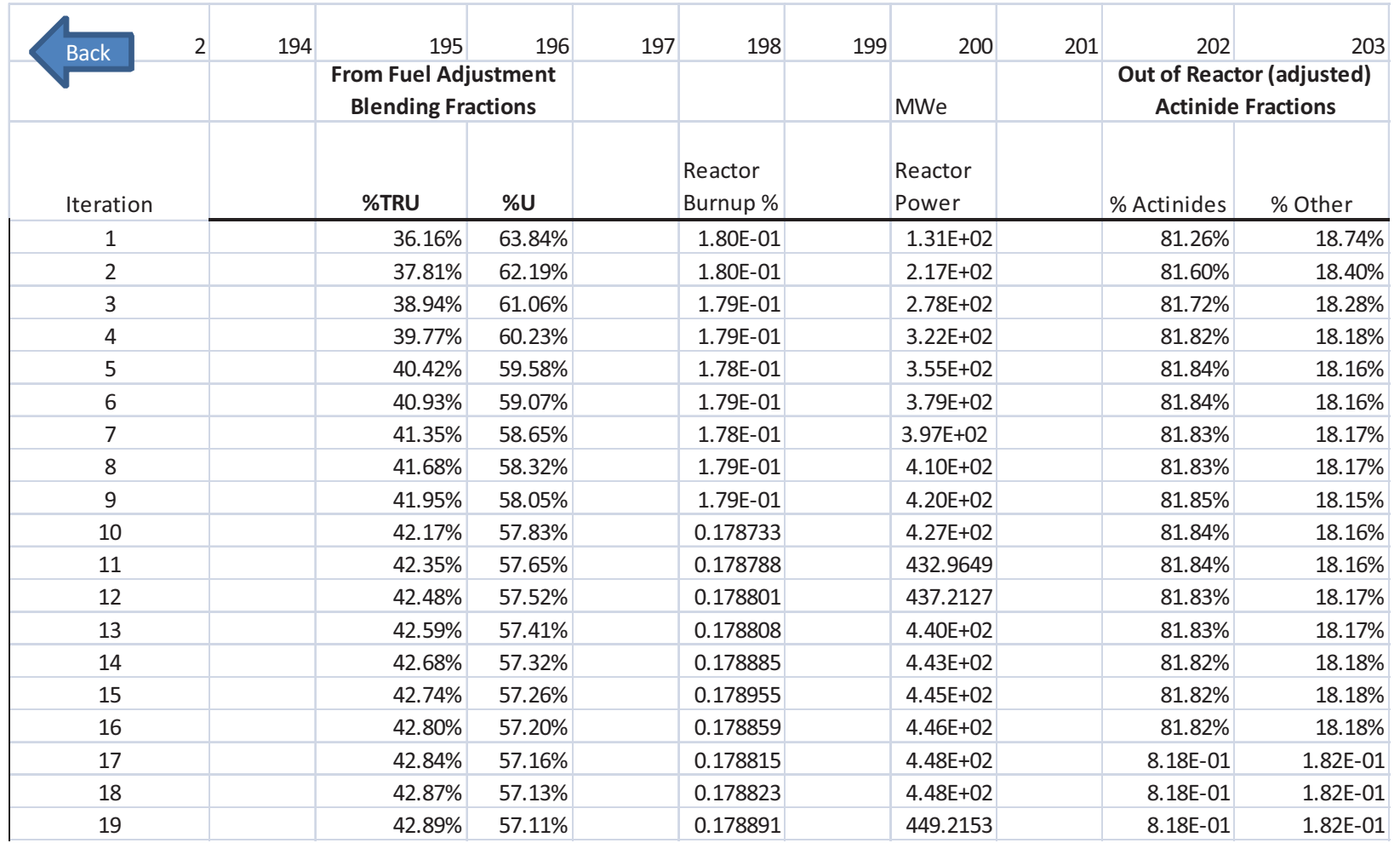

Figure C3. Waste stream output information (continued). 